\title{
Standing in the Shadow of Empire: Ideology in the Path to West Virginia Statehood
}

\author{
Kristen L. Wilkes
}

Follow this and additional works at: https://researchrepository.wvu.edu/etd

\section{Recommended Citation}

Wilkes, Kristen L., "Standing in the Shadow of Empire: Ideology in the Path to West Virginia Statehood" (2018). Graduate Theses, Dissertations, and Problem Reports. 6952.

https://researchrepository.wvu.edu/etd/6952

This Thesis is protected by copyright and/or related rights. It has been brought to you by the The Research Repository @ WVU with permission from the rights-holder(s). You are free to use this Thesis in any way that is permitted by the copyright and related rights legislation that applies to your use. For other uses you must obtain permission from the rights-holder(s) directly, unless additional rights are indicated by a Creative Commons license in the record and/ or on the work itself. This Thesis has been accepted for inclusion in WVU Graduate Theses, Dissertations, and Problem Reports collection by an authorized administrator of The Research Repository @ WVU. For more information, please contact researchrepository@mail.wvu.edu. 


\title{
Standing in the Shadow of Empire: \\ Ideology in the Path to West Virginia Statehood
}

\author{
Kristen L. Wilkes \\ Thesis submitted to the Eberly College of Arts and Sciences \\ at West Virginia University \\ in partial fulfillment of the requirements for the degree of \\ Master of Arts in \\ History/US History, Civil War Era
}

Jason Phillips PhD, Chair

Melissa Bingmann PhD

Kenneth Fones-Wolf PhD

Department of History

Morgantown, West Virginia

2018

Keywords: Empire, Ideology, West Virginia, Capitalism, Industrialists

Copyright 2018 Kristen L. Wilkes 


\title{
ABSTRACT \\ Standing in the Shadow of Empire: $\underline{\text { Ideology in the Path to West Virginia Statehood }}$
}

\author{
Kristen L. Wilkes
}

An empire of industry moved through West Virginia prior to the US Civil War, and saw a breed of capitalists and politicians who acquired control of land through purchase and through patent, developed control of the vote through industrial political influence, and encouraged the West Virginian to separate from an eastern Virginian society based in planter-elite agrarian society. The West Virginian who believed that self-sufficiency and subsistence farming could sustain his family saw his vote for statehood and separation from the Old Dominion transformed into an industrial coup. Land slowly but steadily slipped away from the hands of the mountaineer and into the hands of industrialists who extracted wealth, transforming the new state into an environment that privileged the capitalist and industry above the yeoman farmer. For the industrialists who made West Virginia their home, it appears that extraction of minerals and timber was not the only value taken from West Virginia. Political power and entre into the world of the global industrialist may have been a strong motivating factor, as opposed to simply reaping financial rewards. This work seeks to highlight the influence of these industrialists at the local level in such a way as to demonstrate the weight of this collective group of individuals upon the crafting of West Virginia statehood. 


\title{
Standing in the Shadow of Empire: \\ Ideology in the Path to West Virginia Statehood
}

\author{
Kristen L. Wilkes
}

\section{TABLE OF CONTENTS}

Chapter One

Chapter Two

Chapter Three

Chapter Four

Chapter Five
Introduction

Ideologies

Ideology Becomes Influence

Influence Changes Communities

Conclusion 


\title{
Standing in the Shadow of Empire: Ideology in the Path to West Virginia Statehood
}

\author{
Kristen L. Wilkes
}

Figure 2: $\quad$ Peter Godwin Van Winkle, circa 1864

West Virginia History OnView

West Virginia and Regional History Collection, West Virginia University Libraries

Figure 3: $\quad$ Abraham Lincoln and Peter G. Van Winkle

Figure 4: Johnson N. Camden

West Virginia History OnView

West Virginia and Regional History Collection

West Virginia University Libraries

Figure 5: $\quad$ Henry Gassaway Davis

West Virginia History OnView

West Virginia and Regional History Collection

West Virginia University Libraries 


\section{Standing in the Shadow of Empire: Ideology in the Path to West Virginia Statehood}

Kristen L. Wilkes

LIST OF TABLES and FIGURES

Page No.

Figure 6: $\quad$ Changes to Employment, Slaves Owned,

and Types of Occupations

Comparison between Barbour and Taylor Counties

West Virginia - 1850-1860

Figure 7: $\quad$ Comparison of Farming versus Non-Farming Employment

Barbour and Taylor Counties, West Virginia - 1850-1860

Figure 8: $\quad$ Comparison of Occupations

Barbour and Taylor Counties, West Virginia - 1850-1860

Figure 9: Comparison of Immigrant Employment

Barbour and Taylor Counties, West Virginia - 1850-1860

Figure 10: $\quad$ Comparison of Merchant and Related Occupations

Barbour and Taylor Counties, West Virginia - 1850-1860

Figure 11: $\quad$ View of Grafton, WV, circa 1890,

showing the Baltimore and Ohio Railroad yards.

Note the evidence of active mercantile business facing the yard.

West Virginia History OnView.

West Virginia and Regional History Collection

West Virginia University Libraries

Figure 12: $\quad$ The sun setting on the abandoned

Willard Hotel and B\&O Railroad yard in Grafton, WV.

Author's photo, March 30, 2018 


\title{
Standing in the Shadow of Empire: Ideology in the Path to West Virginia Statehood
}

\author{
Kristen L. Wilkes
}

\section{CHAPTER ONE: Introduction}

America underwent an ideological shift from a republic that participated in a market economy with a sustained interest in preserving the individual agrarian rights to a society that participated in a process of empire that increasingly saw capitalism become a part of state and federal government policy decisions in such a way that industry was privileged above individual citizen rights. This ideological shift was present at the national level during the Civil War era, but is also specifically seen in the schism between eastern and western Virginia legislators, then dramatically evidenced by the actions of industrialists who worked within the statehood movement to enhance the success of industrialism, and ultimately seen in the molding of local identities to fit industrial needs. This work will seek to broaden the understanding of West Virginia's history by placing the statehood movement within the context of this growing connection between industry and government, an ideology of industry that was happening at the national, regional, and local levels. The legislative processes of the Virginia Conventions of 1829-30 and 1850, and West Virginia's Constitutional Conventions provide a framework through which to examine the case that republican ideologies were often shadowed by ideologies of empire, and it was the heavy influence of a growing push toward westward expansion that contributed to the final break of the state. The correspondence of leading politicians, businessmen, lawyers, and industrialists both within the area that became West Virginia and from other states offer context to illustrate the fundamental forces that crafted a state from a shadowy web of conflicted ideologies. ${ }^{1}$ Finally, a case study comparison of two West Virginia counties describes the way that an industry shaped an area to suit its purpose.

This work seeks to examine in three stages the ways that ideology, influence, and industry shaped West Virginia. While there were many men and many businesses across the United States

\footnotetext{
${ }^{1}$ Because this work will include issues both prior to and after the official statehood of West Virginia, the area that became that state will be referred to as "West Virginia" throughout for simplification and ease of understanding.
} 
and within the borders of West Virginia, for purposes of this study, "industrialism" will refer not to a specific business, but to the collective process of moving away from small, independentlyowned businesses and moving toward businesses that were connected to the growing trend of investing in industries with an eye toward future economic gain and which were stabilized by the support of the federal government that relied on those industries for its process of creating empire. The railroad and the extractive industries will figure largely in this study, but it is the shifting allegiance and economic responsibility to forces unconcerned with the future of the West Virginian, rather than the specific industry, that is important. While the interplay between industry and the war effort is important, particularly to the railroad industry, this work will not examine specific war-time relationships between government and industry. Instead, the three chapters of this work will travel from the concept of ideology, to the influence of the political elite, and to the effect of industry on a specific area in order to examine West Virginia's place in the national shift to empire based in industrialization and institutionalized capitalism.

Chapter Two will examine the growing divergence in West Virginia between an ideology of republicanism that stressed economic self-reliance and an ideology that espoused state- and federally-sponsored and supported industries that privileged the political elite and contributed to the national tax base. As the United States moved forward as an independent nation, questions of governance were complicated by questions of funding the security, expansion, and development. Fundamental issues such as internal improvements and taxation plagued the federal government throughout its first eighty years, and these issues loomed large within individual states as well. While the separation of West Virginia from Virginia has been examined on many fronts, the degree to which conflicting ideologies of the use and purpose of industry contributed to the schism of Virginia deserves additional examination. Pertinent to this chapter will be Virginia legislative debates of the 1829-1830 session, illustrating that the process of separation was deep, lengthy, and complicated by not only civil rights issues and political party differences, but was also rooted in fundamental differences of the development of industry. By analyzing the concept of ideology and political influence, defining the shadow of empire that loomed over the western expanse of Virginia can be fleshed out.

Recent historiography on the relationship between capitalism, industry, and individual economic success are important to the discussion of West Virginia's failure to thrive and the state's regular inclusion as a historical non-performer in terms of educational, financial, and social success 
at the national level. Eli Cook's work upon the transformational effect of capitalism in its industrialized form is important to this discussion, as is Wilma Dunaway's examination of the ways that capitalism changed the face of Appalachia. ${ }^{2}$ Steven Stoll's Ramp Hollow provides an excellent example of the ways that national political policy can adversely affect the economies of individual regions, and his work on Appalachia specifically points to West Virginia as an important piece to the study of the ways that industry can transform a place and ideology of industry can transform a nation. ${ }^{3}$ This work points to specific individuals who worked within the ideology of industry, exerted influence over the statehood process and over local identities to change the way West Virginians lived.

Moving from the theoretical discussion of ideology, Chapter Three will examine the lives and practices of several influential men who aligned their economic and political futures with the ideology of industry and empire. The extraordinary influence that was exerted by these important statehood personalities shaped the formation of the state and ushered in an era of extraction of wealth that has extended through the present. By reviewing the personal correspondence and business records of the lawyers, industrialists, and politicians who carefully crafted the process of West Virginia's separation from Virginia, the myth of the independent mountaineer can be swept away and the powerful influence of empire can be more fully understood. This chapter, thus, seeks to broaden historiography of West Virginia to examine more fully the influence of politically elite industrialists who impacted the very creation of the state, and who reaped enormous political and economic rewards from West Virginia. Complex webs of land transactions, corporation structuring, and alliance with out-of-state industry monopolies illustrate that these men were not simply working for the construction of an independent West Virginia; their own personal economic interests and the interests of the larger industrial agents of empire were at stake in West Virginia's statehood.

Prior historiography of West Virginia statehood has been focused on the political events that led up to the actual separation of the state in 1863 , and have carefully examined issues such as geographic differences, religious influence, disputes on the issue of slavery and abolition, and

\footnotetext{
${ }^{2}$ Eli Cook, The Pricing of Progress: Economic Indicators and the Capitalization of American Life (Cambridge, MA: Harvard University Press, 2017).

Wilma Dunaway, The First American Frontier: Transition to Capitalism in Southern Appalachia, 1700-1860 (Chapel Hill, NC: The University of North Carolina Press, 1996).

${ }^{3}$ Steven Stoll, Ramp Hollow: The Ordeal of Appalachia (New York: Hill and Wang, 2017).
} 
the place of birth of citizens/immigrants. Charles Ambler identifies the period immediately preceding the Civil War as a period that saw growth of many factors necessary to support extraction and industry, particularly in the construction of roads and railroads to move valuable resources through and out of the state. ${ }^{4}$ As land was purchased in the west, immigrants and other settlers moved into the area seeking an independence they believed this rich land could provide. As Ambler notes, however, the beckoning markets of the west were calling for products that were being extracted from the Kanawha and Ohio River valleys of West Virginia. With coal production being absorbed in ever-increasing amounts in the Cincinnati markets, industrialists were not immune to the charms of tightening their hold on such valuable resources in the western part of Virginia. ${ }^{5}$ Ambler's early work is enhanced by John Alexander's studies of the many individual industrialists who shaped the massive extractive era in West Virginia after the Civil War. ${ }^{6}$ John Stealey III has provided invaluable insight into both specific industrial impact, such as the Kanawha Valley salt industry and West Virginia's post-Civil War Constitutional debates. ${ }^{7}$ This work seeks to expand the biographical focus of these industrialists to the period prior to official statehood, in order to examine the foundations that were laid to enable and enhance the wealth extraction used by these men within the state, as well as their political and business connections outside of West Virginia.

With the focus trained on a government ideology which privileged industry and capitalism, the influence of West Virginia capitalists established, Chapter Four will utilize the narrow focus of local history to examine the way that influence can shift the demographics and identity of a community. Focusing on the Baltimore and Ohio Railroad (B\&O) and its presence in the area of Barbour and Taylor Counties, West Virginia, this chapter will illustrate the profound shifts that can occur in a place that allows its identity to move from one ideology to another. This chapter

\footnotetext{
${ }^{4}$ Charles Ambler, Sectionalism in Virginia from 1776-1861 (New York: Russell \& Russell, Inc., 1964), 251.

${ }^{5}$ Phil Conley, History of the West Virginia Coal Industry (Charleston, WV: Education Foundation Inc., 1960), 50.

${ }^{6}$ John Alexander Williams, "Class, Section, and Culture in Nineteenth-Century West Virginia Politics" in Appalachia in the Making: The Mountain South in the Nineteenth Century, ed. Mary Beth Pudup, Dwight B. Billings, and Altina L. Waller (Chapel Hill, NC: The University of North Carolina Press, 1995), 210-232.

Williams, Davis and Elkins of West Virginia: Businessmen in Politics (PhD Diss., Yale University, 1967). Williams, West Virginia and the Captains of Industry (Morgantown, WV: West Virginia University Press, 2003).

${ }^{7}$ John E. Stealey III, The Antebellum Kanawha Salt Business and Western Markets (Morgantown, WV: West Virginia University Press, 2016).

Stealey, West Virginia's Civil War-Era Constitution: Loyal Revolution, Confederate Counter-Revolution, and the Convention of 1872 (Kent, OH: The Kent State University Press, 2013).
} 
will utilize census records and local newspaper and personal records to document the way that the B\&O's presence molded a region to suit its national purpose. John Shaffer's Clash of Loyalties honed his focus sharply on Barbour County, West Virginia to analyze patterns of loyalty at the local level, which contributes to the historiography of WV sectionalism. ${ }^{8}$ While not the focus of this Chapter, both Ronald Lewis and Altina Waller have similarly focused upon the local to illustrate the influence of industry in West Virginia. ${ }^{9}$ Lewis and Waller have focused upon the timber industry and illustrate personal and community feuds which illustrate the challenge of negotiating between the shifting ideologies that were at play in West Virginia throughout the Civil War era. This work seeks to amplify the understanding of the subtle, but pervasive, ways that industry shaped and changed regions.

West Virginia's place as a Border State in the Civil War is pertinent to the discussion of how influence at the local level contributed to shifting allegiances that were so critically monitored in the final debate of Union versus Confederate in those Border States. West Virginia's place in the history of the United States is not simply that of an idiosyncratic process by which the state was formed during a time of national war crisis. West Virginia's creation can be measured by the fundamental shift of ideology that rooted progress in the republican virtues of industry and selfreliance, and which is often credited to the rugged Mountaineers who pushed westward across the Blue Ridge and Allegheny mountains. Popular perceptions of the individualist yeoman farmer must be tempered by the understanding that there were factions within West Virginia who were invested in the transformation of the west to an industrial process. The hills and hollows that sheltered the individualists who are portrayed as fiercely independent devotees of Jacksonian republicanism stood in the shadows of the conflict over the direction of American empire that began more than a hundred years before the Civil War. West Virginia's place in America was expertly steered by industrialists, lawyers, and businessmen who believed that the potential of the west could no longer wait for action in Richmond.

8 John W. Shaffer, Clash of Loyalties: A Border County in the Civil War (Morgantown, WV: West Virginia University Press, 2003). See also: John W. Shaffer, Union and Confederate Soldiers and Sympathizers of Barbour County, West Virginia (Baltimore, MD: Clearfield Company, Inc., 2005).

9 Ronald L. Lewis, The Industrialist and the Mountaineer: The Eastham-Thompson Feud and the Struggle for West Virginia's Timber Frontier (Morgantown, WV: West Virginia University Press, 2017).

Altina Waller, Feud: Hatfields, McCoys, and Social Change in Appalachia, 1860-1900 (Chapel Hill, NC: The University of North Carolina Press, 1988). 
The influence of the powerful industrial forces such as the B\&O, Standard Oil, and natural resource extractive operations that began driving the ideology of American empire must also be carefully examined in the question of West Virginia statehood, and local history is an important component to this issue. While individuals within a number (but not all) of the counties that became West Virginia went to the polls to assert their desire to become a separate political entity from the state of Virginia, the interests of these outside industrial forces heavily influenced the crafting of the state. By examining the close relationships that political leaders such as Peter Godwin Van Winkle, Johnson Newlon Camden, and Henry Gassaway Davis had with political and industrial interests outside of Virginia, the depth of non-resident industrial influence upon the formation of the state can be further enlightened.

West Virginia is larger than a regional study because the socio-economic changes observed within small counties touched by the B\&O Railroad echo those same changes across the nation. West Virginia's split from Virginia and subsequent independent statehood is more complex than a simple difference of opinion on the issue of slavery, because there were complex political and economic policy issues at stake. West Virginia is fully deserving of a place at the table of important American history of shifting economic and political identity. By understanding that West Virginia's state-makers participated in the shift to capitalism that was increasingly industrialized by employers in need of wage workers and capitalism that was institutionalized by federal and state governments who made economic policy decisions in terms that increasingly favored the large industrial employer that disadvantaged the individual citizen, present-day limitations within the state's economy are more completely understood. Two recent works, one national and one regional in scope, both point to Alexander Hamilton's policies as central to the ideology of industrialism that became part of the central schism of the Civil War. Eli Cook notes that Hamilton's belief that "national growth and capital accumulation" were consistent with the progress of the nation and that the efforts of the individual, republican farmer ran counter to this march of progress. ${ }^{10}$ Steven Stoll more particularly draws the connection between Hamilton's desire to create federal revenue through the ever-broadening taxation of products, to the industrial motivation to convert the labor of the mountaineer into a system that caused West Virginia to become "enmeshed in the national economy and the global division of labor." 11 This work,

10 Cook, 62-63.

11 Stoll, 92-94. 
ultimately, seeks to illustrate the bridge from an ideology of empire based on industry and institutionalized capitalism, through an elite class of industrial politicians who embraced this ideology, and finally to a lived reality that saw the transformation of West Virginia to an area dependent upon and in service to industry. West Virginia's formation stood in the shadow of empire, with the influence of the ideology of industrialism present throughout the process, the people, and the regions that contributed to the state's creation. 


\section{CHAPTER TWO: IDEOLOGIES}

Early American concepts of republican independence and self-sufficiency contributed heavily to the political ideology shared by many West Virginia residents during the crisis of statehood and ultimate separation from the state of Virginia. Nationalism, the strength of passion and allegiance that people hold for their country can be differentiated from ideology, which represents a set of beliefs that assign power within a group or society. The ideology of republican independence was not the only form of ideology that shaped West Virginia's statehood, as the antebellum period saw a competing ideology of empire rooted in a growing sense of government support of industrialism and extraction of resources. Ongoing conflicting ideologies of republicanism and empire were at play on the larger scale of nation, culminating in separation into Union and Confederate forces. Conflicting ideologies of empire are reflected in the debates of the Virginia Legislature for thirty years prior to the Civil War, with increasing questions about the federal government's role in the conversion of individual property rights and the fruits of individual labor to the use and benefit of the nation. ${ }^{1}$ The fundamental rights of the American citizen to participate in government have been traditionally reported as the core process that culminated in the separation of Virginia into two separate states, but the influence that an ideology of empire rooted in industrial expansion had upon the state's internal division deserves attention.

The heredity of empire that landed upon the soil of North America with the first European settlers is one that encompassed both the power of the state and the "pattern of political relationships which held together groups of peoples" across a territory. ${ }^{2}$ As Thomas McCormick notes, European patterns of imperialism cast a long and deep shadow upon the United States, despite the "popular myth" that Americans had escaped the European model of expansion. ${ }^{3}$ The terminology of empire also denotes that the citizenry within the territory of the political realm will adhere to "a particular kind of life," an ideology that binds together people across a span of space. ${ }^{4}$ The United States, despite its revolutionary cries of republicanism during the War of Independence, reached a crisis of identity that culminated in the Civil War as a crisis of empire.

\footnotetext{
1 Stoll, 93.

2 Anthony Pagden, Lords of All the World (New Haven, CT: Yale University Press, 1995), 13.

3 Thomas McCormick, "From Old Empire to New: The Changing Dynamics and Tactics of American Empire," in Colonial Crucible: Empire in the Making of the Modern American State, ed. Alfred W. McCoy and Francisco A. Scarano (Madison, WI: The University of Wisconsin Press, 2009), 63.

${ }^{4}$ Pagden, 18.
} 
The crisis can be characterized by competing groups of elites with ideological differences, and in an area open to the creation of a new state with new avenues of power and a heavily divided populace, the political elite were able to craft a state to suit their interests. John Alexander Williams notes that "there developed in western Virginia a resident ruling class that, as it emerged to maturity after 1830, drew its most influential leaders from lawyers who specialized in land litigation and speculation." ${ }^{5}$

Michael Adas notes that Thomas Jefferson's well-recognized "agrarian idealism" had been effective in the United States at a time when the country was "transformed from a patchwork of settlement colonies into a nation, technological advance was increasingly seen as essential to the growth and well-being of the fledgling republic." ${ }^{\prime \prime}$ As America grew and expanded west, lands previously occupied by Native Americans were increasingly perceived as "unused" lands and appropriated for use by the empire. William G. Robbins' work on capitalism in the American West compares the "appendage" relationship between the west and the financial centers of the east was one of nearly exclusively extractive industries. ${ }^{7}$ Robbins goes a step further and finds that this type of relationship in the American empire was not singular to the American West, noting that the system of non-resident ownership of extracted resources is similarly seen in Appalachia. Robbins likens the system to the broader concept of empire, wherein "the region was part of the wider subordination of colonial sectors to the requirements of metropolitan-based economies." Steven Stoll identifies the original usefulness of those who settled the area of West Virginia and provided a buffer between the elite and the natives who stood in the way of the expanding boundaries of the United States. ${ }^{9}$

Westward expansion of the nation required geographic areas and the citizens who inhabited those areas to shift and negotiate their social and economic relationships with the eastern metropolis. Conflict over control of land and market opportunities frequently occurred in the west, and antebellum settlers attempted to maintain their socio-economic traditions in the face of a federal government that was actively seeking opportunities to enfold them into a different form of

\footnotetext{
${ }^{5}$ Williams, "Class, Section, and Culture in Nineteenth-Century West Virginia Politics," 217.

${ }^{6}$ Michael Adas, Machines as the Measure of Men: Science, Technology, and Ideologies of Western Dominance (Ithaca, NY: Cornell University Press, 1989), 404.

${ }^{7}$ William G. Robbins, Colony \& Empire: The Capitalist Transformation of the American West (Lawrence, KS: University Press of Kansas, 1994) 16.

${ }^{8}$ Ibid., 62.

${ }^{9}$ Stoll, 11.
} 
market economy - one that would support industrial interests and extractive businesses. Production served the interests of the federal government by creating items with potential for taxation, which could provide the revenue necessary to protect and enhance westward expansion. William Hogeland places the Whiskey Rebellion as an example of the federal government's attempt to monetize products produced on the western frontier in order to harness revenue to repay capitalist investment in the United States' military and government expenditures. ${ }^{10}$ The conflict over the place of government and industry, the intrusion of large-scale land control outside the sphere of the subsistence farmer, and the movement of the independent farmer to an industrydependent wage worker similarly placed West Virginia in a state of transformation at the critical time period of the Civil War.

The empire of industry moved through West Virginia, acquiring control of the land through purchase and through patent, developed control of the vote through industrial political influence, and encouraged the western Virginian to separate from an eastern Virginian society based in planter-elite agrarian society. The West Virginian who believed that self-sufficiency and subsistence farming could sustain his family saw his vote for statehood and separation from the Old Dominion transformed into an industrial coup. As West Virginians shifted their energies to employment in extractive industries, they became less self-reliant in society and had to increasingly rely upon the work of their family (wives and children) to develop and maintain their subsistence farms in order to survive. These families were then not able to engage in education or other means of advancement/self-improvement in order to make economic gains. The transformation from independent subsistence farmer to industry-employed wage earner in itself created a power imbalance. Eli Cook points to the fundamental freedom that was enjoyed by the self-sufficient farmer, for whom the "central purpose of land or other forms of productive property was not generating cash flow but maintaining self-rule."11 The ability to own and use land productively was central to independence.

West Virginia's motivation to connect with the might of national industry is evident, such as when the Monongalia Mirror on October 20, 1849 published a report of the B\&O Board, to look toward West Virginia as a gateway to the immense possibility that the American had to offer

\footnotetext{
${ }^{10}$ William Hogelund, The Whiskey Rebellion: George Washington, Alexander Hamilton, and the Frontier Rebels Who Challenged America's Newfound Sovereignty (New York: Scribner, 2006), 36-40.

${ }^{11}$ Cook, 86.
} 
as an inducement to more rapidly advance construction of the $\mathrm{B} \& \mathrm{O}$ line to Wheeling. The $\mathrm{B} \& \mathrm{O}$ connected itself to the west, and elucidated the immense possibilities that awaited the residents of West Virginia, should the final connection be established:

No portion of our Union, whether considered in reference to the agricultural resources, or the genius and enterprise of its population, can be said to compare with the vast regions lying west of the Ohio River -whose affection is now directed to this market, as the nearest and most convenient for its surplus markets. ${ }^{12}$

The report goes on to remind readers that, with the connections of the $\mathrm{B} \& \mathrm{O}$ and the Baltimore and Susquehanna railroad line, the market would provide the Board of Directors assurances of a future ability to reap from nature the most "lavish of her gifts." 13 While Virginia was not immune to the charm of railroad expansion, the state legislature devoted substantial sums into the improvement and development of lines that would connect with southern railroads, as opposed to those lines reaching into the western regions. The Wheeling Intelligencer reported on January 31, 1853 that the "South Side Railroad bill, the Central Railroad bill, and the Manassas Gap Railroad bill" were passed in session, with two of those projects connecting to the deep South and the remaining line not yet determined whether to align with the $\mathrm{B} \& \mathrm{O}$ or not. ${ }^{14}$ But, West Virginia's industrialists were not only interested in bringing the $\mathrm{B} \& \mathrm{O}$ to West Virginia for the benefit of the state, they were particularly interested in preserving their own economic interests, whether within the state or without. Lewis County resident Henry Brannon, engaged in an extensive letter writing campaign to attorney Robert Waters to solicit capital to construct a railway to connect to the $\mathrm{B} \& \mathrm{O}$ line that traversed the state in the northwest region in order to reap the benefit of the: "timber of the finest quality, coal and iron, and.... a soil naturally rich and adapted to grazing, and a climate as healthy, I may say, as anywhere in the United States." 15 Brannon kept up an active campaign to Waters over the course of more than five years, during which time the scope of the railroad project continued to dwindle and Brannon began to request assistance with obtaining not funds to develop

\footnotetext{
12 Extract from the "Annual Report of the President and Directors of the Baltimore and Ohio Railroad, by Thomas Swann, President." Published in the Monongalia Mirror, October 20, 1849. West Virginia University Library (WVU), West Virginia Regional and History Center (WVRHC), Microfilm Collection, Morgantown, WV. 
his home state of West Virginia, but tips on how to invest in "the more inviting fields in the West." 16

West Virginia has been studied as both a border state and a state born of war for most of its history, and an important aspect of the nature of a border state is the uncertainty and state of transformation that often accompanies such an area. Patrick Griffin specifically places conflicting issues of sovereignty and conflicting ideas of empire within the liminal area that made up a border state:

More than a line, zone, borderland, or process, frontier is a place in time on the edge of intersecting broader worlds defined by competing notions of sovereignty, human difference, land, and society. At the intersection of the tow, distinctive conceptions of landownership, the relationship between individuals and society, and ways of conceiving other groups converged and clashed but were ultimately transformed, redefined, and resolved. Flux and uncertainty therefore marked both, which only the state could remedy and myth obscure. ${ }^{17}$

While West Virginia's has been frequently placed on the western frontier in terms of its response to traditional issues such as legislative representation and the question of abolition, the state might also be studied as a border state and relative to the transformation that resulted from the political influence of the men whose personal economic interests benefitted heavily from West Virginia's extractive and industrial potential. Economic challenges put down roots as firmly as any mountaineer at the time of statehood, and historians have examined many causes for the failure of a state so rich in natural resources to thrive. The growing American maxims of westward expansion and industrial growth found fertile ground in which to plant their seed of ideology in a geographic area whose people were conflicted over interpretations of the US Constitution and their relationship to the state of Virginia. While the intent of West Virginians included a desire for equal representation in the legislature and consideration of needs other than those of the planter elite, national players such as the $\mathrm{B} \& \mathrm{O}$ and Standard Oil found a home among the hills in West Virginia, and the voices of industrial concern were equally powerful in the construction of the state.

\footnotetext{
${ }^{16}$ Henry Brannon to Robert H. Waters, Esq., February 12, 1881, letter. A\&M 3116, Henry Brannon, Lawyer, Papers. WVU WVRHC, Morgantown, WV.

17 Patrick Griffin, American Leviathan: Empire, Nation, and Revolutionary Frontier (New York: Hill and Wang, 2007), 15.
} 
At its core, construction of government is primarily an argument over who holds the power of decision-makings, and who controls the resources. For a nation, modern governments have sought to achieve a balance of power that eliminates the risk of allowing despotic rule. In the United States, the balance of power is easily recognizable by the three branches of government which are designed to separate decision making between the legislative, judicial and executive branches. But, perhaps, power does not solely lie within the neatly constructed elements of these government branches. Power is mutable and gains strength from perception. The belief of a citizenry that a people, an industry, or an ideology can change their lives and their futures is more powerful than any written or legislated construct of power. Concerns over where power rested have been central to political debate throughout the history of the United States, and a specific concern arose in the early days of the republic concerning the power wielded by those with enormous wealth. ${ }^{18}$ The theory of democracy upon which the United States was founded attempted to alleviate the danger of an elite class "viewed as using their privileged access to government to multiply personal fortunes." 19 John Adams believed that the problem of the influence of the aristocratic, wealthy, or elite, would not disappear with the crafting of a different form of government through a balance of power. ${ }^{20}$ The structure of the three branches of government within the United States was designed to provide a stop-gap measure to ensure the citizenry a strong voice in their governance. With that power, the influence of an espoused ideology becomes especially strong: to influence all three branches of government, the populace must adhere to a common ideology. ${ }^{21}$ It is the power of ideology that originally shaped the United States and has reshaped it at every turn; the shaping of West Virginia was no exception and that shaping was distinctively formed by the influence of the wealthy and elite who valued economic advantage over individual freedom. Judge Phillip Barbour, addressing the 1829-30 Virginia Convention noted that:

But, while faith, is the surest of all foundations in matters of religion, the very reverse of faith, is the true foundation of all free Governments. They are founded in jealousy, and guarded by caution; nor can the spirit of liberty long survive among any people where this jealous vigilance is not kept in perpetual vigour."

\footnotetext{
${ }^{18}$ Luke Mayville, John Adams and the Fear of American Oligarchy (Princeton, NJ: Princeton University Press, 2016), 23.

19 Ibid., 31.

20 Ibid., 42.

21 Ibid., 32-33.
} 
And....."throughout a great part of this discussion, gentlemen have confounded civil rights with political power. An argument which goes for the security of civil rights involves consideration of one kind; while an argument for the distribution of political power, involves consideration of a very different description. ${ }^{22}$

In order to maintain a firm grip on the resources of West Virginia, industrialists seeking to extract those resources had to ensure their capacity to gain title to the land under which or upon which those resources were held. According to Johanna Haas, extraction of resources was closely tied to land ownership, which had been cultivated and collected by out-of-state businessmen. ${ }^{23}$ While West Virginians similarly saw the vast resources of their state, and lamented their inability to extract that wealth for their own use, the legislative processes constructed to rectify the internal improvement problems benefitted industry and absentee landowners, with little regard to the economic success of local communities. Land slowly but steadily slipped away from the hands of the mountaineer and into the hands of industrialists who extracted wealth, but did not stay to maintain the pristine wilderness. As Haas notes:

In order to gain the necessary control over the landscape and extract its wealth, industry needed to remove the land from the hands of the people living there, and gain ownership. In Appalachia, this process happened in ongoing waves occurring from the Colonial Era through today. ${ }^{24}$

For the industrialists who recognized West Virginia's bounty of natural resources, minerals and timber were not the only value taken from that area. Political power and entré into the world of the global industrialist may have been a strong motivating factor, as opposed to simply reaping financial rewards. In fact, industries demonstrated the power to create communities to support the industry in such a way that political support for that industry was implicit. The Monongalia Mirror reprinted, from the Baltimore American, an article touting the benefits of the $\mathrm{B} \& \mathrm{O}$ as critical to reducing the time to travel between prominent trade locations like Cincinnati and New York, and providing additional inducement for the progress of the train. "It has been found that these improvements work like a charm in behalf of capital - enhancing, prodigiously, the value of real

\footnotetext{
22 Proceedings and Debates of the Virginia State Convention of 1829-30: To Which are Subjoined the New Constitution of Virginia, and the Votes of the People (Richmond, VA: Samuel Shepherd \& Co., for Ritchie \& Cook, 1830), 97.

${ }^{23}$ Johanna Marie Haas, J.D. "Law and Property in the Mountains: A Political Economy of Resource Land in the Appalachian Coalfields" (PhD Diss., The Ohio State University, 2008), 41.

${ }^{24}$ Ibid., 69-70.
} 
estate - and in building up cities, towns and villages where no prophet would have dreamed it possible to sustain them." 25

Influence over local West Virginians was certainly utilized in development strategies, according to Williams, who identifies the method by which industrialists aligned "their private interest with the public welfare and to pursue it successfully by political means, whether or not their identification of public and private goods was correct." 26 These industrialists exerted influence at the state and at the local level in such a way as to shift allegiance away from eastern Virginia's pattern of governance and toward separate statehood that could more closely match their concept of expansion. In fact, the shift in government practices is implicit in the alignment with a national ideology that utilized both public and private property to the benefit of the empire/nation-state. Steven Stoll identifies taxation as one of the most pervasive ways that the federal government has the ability to extract power and distribute money to support industries that are supportive of the national need: "[g]overnments attempted to capture the value they created through taxation (the United States) and by offering up the landscape to corporations (the state of West Virginia)."27

Not only were the practices of industrial extraction similar in the west and in areas of Appalachia such as West Virginia, but there was overlap of the important players, including Standard Oil, who operated throughout the American West in areas such as Pueblo, Colorado and Butte, Montana, and who also wielded a heavy (if unseen) influence in West Virginia through individuals who operated both within West Virginia and outside that area. ${ }^{28}$ Lands in Appalachian West Virginia were appropriated for use by the empire because those lands were perceived as being not used to their industrial potential. As America gained footing after the War for Independence and began to assert power, the nature of business management changed. Where once the Jeffersonian principles of free-market exchange could be seen in the small shop owner, the small farmer, and other similar enterprises, with the "emergence of the newly integrated world of monopolylike industrial combinations," the needs of the public were not the only needs served by the state and national government. ${ }^{29}$ By necessity, businesses whose reach extended beyond

\footnotetext{
25 "Railroad Items," Monongalia Mirror, November 10, 1849. Microfilm Collection, WVU WVRHC, Morgantown, WV.

${ }^{26}$ Williams, West Virginia and the Captains of Industry. 174.

${ }^{27}$ Stoll, 33.

${ }^{28}$ Robbins, 93.

${ }^{29}$ Ibid., 103.
} 
the bounds of their immediate regions through a network of supply and demand and "distant outposts of settlement" and further into the transnational world, could not attend to the economic and social needs of a select region. ${ }^{30}$ The bottom-line was the economic security that motivated corporations, as opposed to the social needs of a community that often motivated business owners in the early days of the republic. As the federal government sought revenue to fund its westward reaching nation's security and expansion, taxation of products created by a wage working public became increasingly viable. ${ }^{31}$

The firm commitment of the United States to imperial practice of foreign expansion and colonialism at the turn of the century confirms that antebellum patterns of empire were leading to the profound shift in the way America did business that resulted in manufacturing and industrial businesses ready to challenge global forces. ${ }^{32}$ While the United States may have modified the visible signs of empire, the practice of expansion and use of ideology to sustain allegiance among vast territory remained constant as the nation pushed west. Virginia's internal constitutional crisis had been debated over the years as representative of conflicts over abolition, over religion, over taxation, and over representation in the legislature. "Jefferson's 'empire of liberty' was in fact an empire of slavery and exclusion. But it was also an imperial republic that repudiated the widespread belief that the power and prosperity of states depended on the economic and fiscal resources of colonial possessions." 33

The power of a state and a nation to influence the day-to-day life of citizens is part and parcel of the way that ideology roots a nation or an empire and connects people across wide expanses of territory. The relationship that people have to their government is an expression of their relationship to power and how they believe the power of their government should be used. Michael Woods posits that it is through emotional response that antebellum America registered their response to power and their commitment to one form of ideology or another, binding themselves firmly to a particularly ideology: "[t]he prevalence of these emotions - including indignation and jealousy - in antebellum political discourse suggests that emotional responses to

\footnotetext{
${ }^{30}$ Robbins, 105.

31 Hogeland, 52-55.

${ }^{32}$ McCormick, 68.

33 Justin Du Rivage, Revolution Against Empire: Taxes, Politics, and the Origins of American Independence (New Haven, CT: Yale University Press, 2017), 22.
} 
political events primed Americans to think in uncompromising terms of good versus evil. ${ }^{34}$ James Madison, during the Virginia convention of 1829-30, similarly recognized the fact that strength of emotion motivated citizens to allegiance:

A still more fatal if not more frequent cause, lies among the people themselves. All civilized societies are divided into different interests and factions.........Whenever therefore an apparent interest or common passion unites a majority what is to restrain them from unjust violations of the rights and interests of the minority, or of individuals $?^{35}$

Phillip Doddridge's remarks in the 1829-30 Convention echo the power that emotion can have to sway a populace by alleging that the eastern Virginians were attempting to malign the people of the west by framing them publicly as radical, rabble-rousers:

Writers on one side endeavored, by exposing the misrule of the minority, and the evil tendency of that rule, to awaken public attention to the subject, and to bring about reform. On the other hand, attempts were made to alarm the people. They were taught to believe that those who proposed to reform, meant to destroy; that the judicial tenure of office, the right of suffrage, and even property of a certain description, nay, all that was valuable in society, would be hazarded by the call of a Convention. ${ }^{36}$

Both politicians recognized that emotions had the power to convert people to an ideology that emotions were utilized by the political elite to sway a citizenry toward a brand of ideology, and could be called upon to incite movement. Politicians were skilled in utilizing emotional responses to move citizens, and industrialists were skilled in utilizing politicians to engage these emotional responses.

What separated Union and Confederate ideologies has been disputed heavily for more than one-hundred-fifty years and both sides of the conflict had distinct views on the direction that the empire of America should take. The crisis was not a single-issue crisis, as the needs of various regions of the Confederacy and within the Union held different issues as critical - including questions of abolition and questions of economic policy. The complex issue of how to fund national issues such as military protection was increasingly open to a debate over whether

\footnotetext{
${ }^{34}$ Michael E. Woods, Emotional and Sectional Conflict in the Antebellum United States (New York: Cambridge University Press, 2014), 2.

35 James Madison, May 7, 1787, "Vices of the Political System of the U. States," accessed January 13, 2018, https://www.loc.gov/resource/mjm.02_1005_1013/?sp=7\&st=text.

36 Proceedings and Debates of the Virginia State Convention of 1829-30, 82.
} 
individual states were adequately protecting the capital investments made by large bond-holders, who pressured the federal government to ensure their repayment through revenue. ${ }^{37}$ A government position that privileged producers of taxable products was more inviting to investors than was a government position that encouraged independent agrarian interests. West Virginia stood squarely in the middle of this argument as a border region, because an empire cannot allow any portion of its territory to fall, emotions on both sides of the ideological argument were high. McCormick locates the region that became West Virginia within what he calls the first wave of American empire during the Revolution:

which was not only a war against empire but a war for empire and a grandiose one at that. Indeed, in the American revolutionary crosshairs were the trans-Appalachian West, Canada, Florida, and the British West Indies. In the end, the United States acquired only the first item on that imperial shopping list, laying the groundwork for American dominance of the Ohio and Mississippi valleys. ${ }^{38}$

Justin Du Rivage's political history Revolution Against Empire similarly questions the traditional narrative of the American Revolution as a push-back against taxation, framing the action as a more basic dispute over which direction the British Empire should take. ${ }^{39}$ This theory can similarly be applied to an examination of whether men living west of the Appalachian Mountains had significant tax disputes with their legislature in Richmond, or if they simply wanted the state to move in a different economic direction. Not only did the leaders of the statehood movement believe that the ideology of the east was stagnated in an economic position that was preventing the advancement of the west, they believed that the political structure of Virginia state government was, itself, a modified version of the British Empire that did not fit the political ideology of the growing United States strategy. Delegate Philip Doddridge from Ohio County in the western region of Virginia, addressed assembled delegates at the 1829-30 Virginia convention, and characterized the original framers of the Virginia Constitutional framework as men who were used to the traditional monarchial rule of Great Britain, who had been part of the House of Burgesses. Doddridge asserted that the politicians making original laws and procedures for the state of Virginia did not construct a government that differed from the status quo of political rule they were accustomed to under British rule, but that:

\footnotetext{
37 Hogeland, 53.

${ }^{38}$ McCormick, 64.

${ }^{39}$ Du Rivage, 10-11.
} 
[t]he Convention of 1776 , did little more than to continue the existing state of things. In the place of the old House of Burgesses, they erected the House of Delegates, while the Legislative Council gave place to the Senate; each new branch possessing precisely the powers, and privileges of its predecessor; and the members possessing the same qualifications respectively, and elected by the same electors. The Executive head was, alone, substantially changed. ${ }^{40}$

The Daily Wheeling Times reprinted a report from the Virginia General Assembly on January 19, 1849, that urged the Legislature to strongly consider the threat their ongoing resistance to westward expansion was creating (Tyler presenting): "The excited spirit of the age is seeking for a boundless extension of our territories. Is it reasonable for us to expect the people of the North to permit this institution against which they have moral, religious, and social objections, to be inflicted upon them in these new territories? - Sir, if you stake the Union on that issue, it will be a stake lost."41 Of particular note are two items that appeared on the same page of the Wheeling Daily Intelligencer on January 31, 1853: one congratulatory item welcomed the news that the United States Department of State as its official publisher, a contract the publisher believed would "add greatly to the interest and usefulness of our paper." 42 The second item strongly cautioned the eastern Virginia Richmond Whig newspaper to cease neglecting the need to recognize the $\mathrm{B} \& \mathrm{O}$ as integral to the success of the city of Wheeling, which the Whig's publisher warned should be given serious consideration in the capital of Virginia. ${ }^{43}$

Waitman Willey, delivering a speech before the Virginia legislature on March 2, 1861, demanded that the practice of the purchase of land by the federal government through the Louisiana Purchase firmly established that the intent of the United States was for the "protecting and encouraging the great trade of the interior empire of States." 44 In his impassioned speech to attempt to persuade the Virginia legislature from secession, Willey argued that indulging in the differences of ideology would continually create artificial hostile borders that would erode the

\footnotetext{
40 Proceedings and Debates of the Virginia State Convention of 1829-30, 80.

41 "General Assembly of Virginia," Daily Wheeling Times, January 19, 1849. Microfilm Collection, WVU WVRHC, Morgantown, WV.

42 “Congressional Printing," Wheeling Daily Intelligencer, January 31, 1853. Microfilm Collection, WVU WVRHC, Morgantown, WV.

43 Ibid..

44 "Speech delivered by Waitman T. Willey, of Monongalia, on Mr. Moore's Resolutions on Federal Relations, In the Convention of Virginia, March 2, 1861," accessed January 31, 2018, http://www.wvculture.org/history/sesquicentennial/18610304.html.
} 
power and strength of the American people. Finally, Willey urged his eastern brothers to consider the great wealth and opportunities that lay within the western regions of Virginia: "mineral resources and recently discovered fountains of oil, extensive enough to furnish the basis of an empire's greatness; and these, when developed, will necessarily add to the power and wealth of the whole State."45 The railroad and its advance to the Pacific edge of the United States was Willey's siren song to the statehouse, when he urged Virginia to claim her link in the chain of progress and empire rather than to "join some miserable Southern Confederacy, as a mere outside appendage." 46

Du Rivage's methodology suggests close examination of traditional narratives at times of crisis to determine whether the basis of the argument matches the narrative. A brief examination of demographics in Virginia throughout the antebellum period point to similarities that bring into question the motivation of western residents to split from their eastern brothers. A review of 1850 and 1850 census data demonstrates that it is the ideology of government support of capitalism and the emotional attachment to the ideology that is more critical to the direction of a political entity or government than lived reality. Both eastern Virginia and West Virginia saw similar population growth and increased value of their farm land between 1850 and $1860 .{ }^{47}$ In reality, the western counties of Virginia had a decrease in the total number of citizens employed in manufacturing, while the eastern counties saw an increase in manufacturing employment. It is not, thus, the reality of the experience that created a shift in political ideology; rather it was the possibility of change and the emotional attachment that was associated with the shift in ideologies.

\footnotetext{
45 "Speech delivered by Waitman T. Willey."

46 Ibid..

${ }^{47}$ U.S. Census Data, 1850 and 1860 Virginia (by county), select data extracted via Steven Manson, Jonathan Schroeder, David Van Riper, and Steven Ruggles. IPUMS National Historical Geographic Information System: Version 12.0 [Database]. Minneapolis: University of Minnesota. 2017. http://doi.org/10.18128/D050.V12.0.
} 


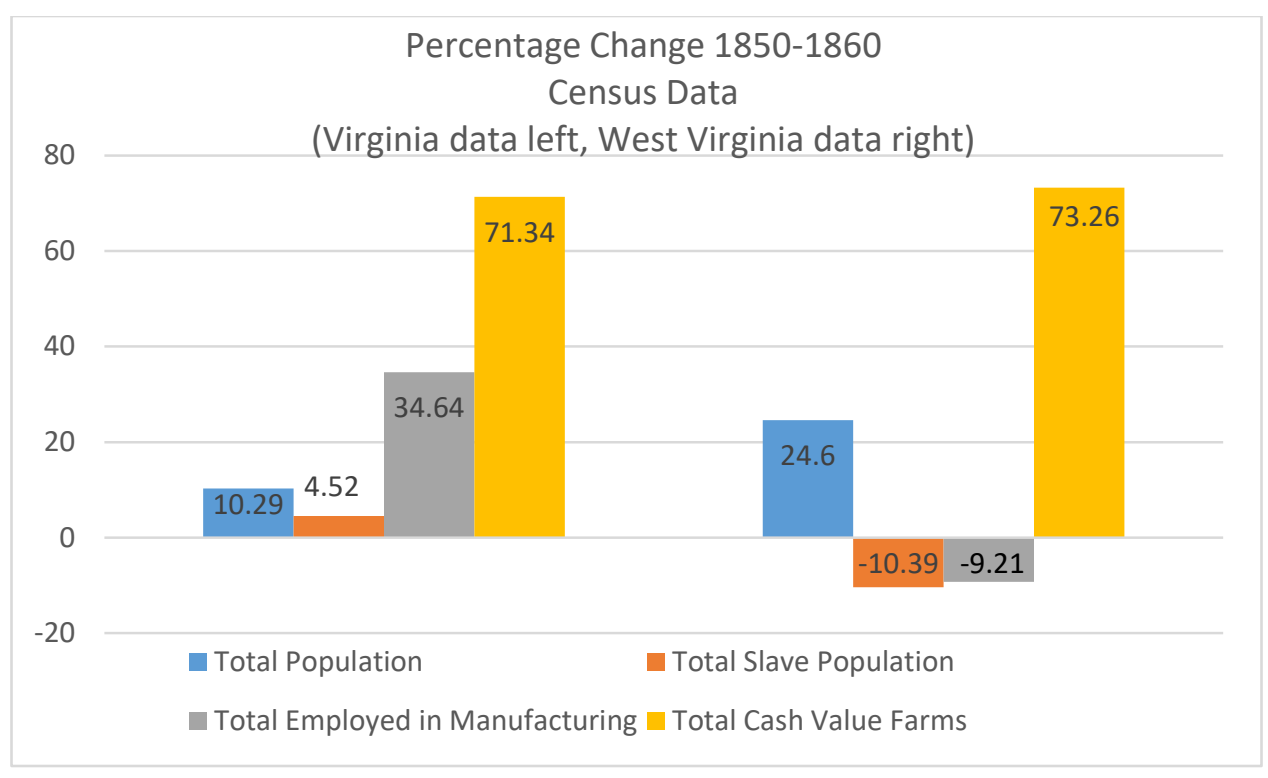

Figure One: 1850-1860 Census Changes Virginia Counties versus West Virginia Counties

Newspaper professionals in the West Virginia recognized that the stirring of emotion through print was a powerful way to induce the population towards the political interests favored by the editors. Archibald Campbell, editor of the Wheeling Intelligencer, received a correspondence from the editor of the Wellsburg Herald on March 23, 1860, suggesting that the two papers consider coordinating their efforts to publish regular articles supporting the proposed convention at Wheeling. ${ }^{48}$ Campbell was also cautioned that the secessionists in the Wellsburg area were inspiring increasing support and that the newspapers should "concentrate and organize the feelings" to motivate citizens to the Union cause. ${ }^{49}$ Archibald Campbell, editor of the Wheeling Intelligencer, in his "Salutory" editorial on October 9, 1856 firmly inserted his newspaper in support of the "manufacturing and commercial facilities" that were the lifeblood of his city and to whose interests he believed he had a duty to protect. Wheeling was long primed and ready to accept the traffic of empire, recognizing that the west represented "a great commercial reservoir," to be tapped by the enterprising men who would engage with the competition of railroad interests who sought to open the tap. ${ }^{50}$ John Alexander Williams notes that, prior to 1880 , the only area

\footnotetext{
${ }^{48}$ Editorial office of the Wellsburg Herald to Archibald Campbell, March 23, 1860, letter, A\&M 14/61, Folder 3 Archibald W. Campbell (1839-1899), Newspaperman, Papers (Morgantown, WV: WVRHC).

49 Ibid.

50 Wheeling Daily Intelligencer, February 3, 1853. Microfilm Collection, WVU WVRHC, Morgantown, WV.
} 
with a daily newspaper was the more heavily industrialized city of Wheeling, while "[o]f the thirty secular weeklies published in 1860, fourteen were based along the B\&O or the Ohio." 51

A shifting ideology in the west more clearly defines the urgency of separation that split the state and pushed the western regions toward a connection to industrial interests. This ideology of westward expansion based upon commercial interests was not a new idea, but had lived in the American psyche since formal settlement began. No less than Thomas Jefferson, father of the foundational documents of the United States, identified commerce as critical to the burgeoning empire of America and laid the foundation of empire that ultimately shaped the future process of West Virginia's statehood:

This is the moment however for seizing it if ever we mean to have it. All the world is becoming commercial. Was it practicable to keep our new empire separated from them we might indulge ourselves in speculating whether commerce contributes to the happiness of mankind. But we cannot separate ourselves from them. Our citizens have had too full a taste of the comforts furnished by the arts \& manufactures to be debarred the use of them. We must then in our own defence endeavor to share as large a portion as we can of this modern source of wealth $\&$ power. ${ }^{52}$

Not only did the American people illustrate the propensity for commerce that Jefferson recognized, but American politicians swiftly recognized the potential of commerce to create a basis for taxation. The crafting of a state called West Virginia was deliberate, even if it was unrecognized by the citizens, as a part of the process of empire. West Virginians were not necessarily deciding upon whether or not they were "Northern" or "Southern" or "Union" or "Confederate," but were engaged in a battle over what type of empire they wanted to be a part of - a part of the empire that relied upon slave labor or a part of the empire that relied upon wage labor; the question of whether the empire should encourage federal policies that privileged industry over individual were central to these questions. While West Virginia may have existed in the liminal state - in between the metropol of the east and the expanding frontier of the empire, the resources of the area were highly valued both within and outside the region. The potential growth of the region did not escape the attention of politicians, newspapermen, and businessmen. This issue points to why Border States

\footnotetext{
51 Williams, "Class, Section, and Culture in Nineteenth Century West Virginia Politics," 215.

52 Thomas Jefferson to George Washington, March 15, 1784, letter, Ronald M. Gephart, ed., Letters of Delegates to Congress: 1774 to 1789 (Washington, DC: Library of Congress, 1994), 431.
} 
were so central to the Civil War - not necessarily whether or not they would be slave states or free, but whether they would align with the power structure that was the underpinning of the two competing forms of empire.

Legislators from West Virginia valued the concept of labor of self, even as early as the 1829-30 Convention, when Delegate Campbell, from Brooke County advised his fellow delegates that the eastern regions should become aware of their stagnant ideology:

He had been so much engaged in fortifying his amendment from deductions from Cocker's arithmetic the evening before to shew that while the wise men all came from the East, the march of empire was to the West, that his mental lights were, for the time being, eclipsed. ${ }^{53}$

Virginia's legislative debates clarify that the eastern bloc felt clearly that the right to hold power was a right that rested with an exclusive few. They also recognized that the financial and economic interests of an area committed that area to the specific ideology held by those in power who, in turn, protected that ideology through legislation and political support. Judge Abel P. Upshur addressed the 1829-30 Virginia convention with a speech that posited that power should only belong to a majority when: "there is an identity, though not an equality of interests, in the several members of the body politic: in which case the presumption naturally arises, that the greater number possess the greater interest. But the rule no longer applies, when the reason of it fails." 54 Without a shared ideology, the power structure in Virginia could no longer remain, and eastern concerns did not intend to allow a growing population in its western regions to overtake the government by voting upon economic issues that did not conform to the identity and ideology of the east. Eastern legislators also recognized that the representatives from the west were singularly devoted to internal improvements that would, by design, remove their interests from those legislators who sought to protect the economic interests of the east. Delegate Thomas Joynes also admonished the western bloc that they were putting the desire for internal improvements in their pursuit of economic interests above the interest of the public who was taxed to support those interests:

It has been frequently said in the progress of this debate, that the object of Western gentlemen in wishing the white basis to be established, was to enable them to obtain the passage of laws for the

53 Proceedings and Debates of the Virginia State Convention of 1829-30, 119.

54 Ibid., 70. 
promotion of a system for the internal improvements of their country. I thought the magnanimity and candor of gentlemen would prevent them from denying that that was one of their primary objects. What else can be their object? Does any gentlemen pretend that the security of personal rights requires the adoption of this principle ${ }^{55}$

John W. Green, delegate from Culpepper, echoed Joynes, voicing his concern that the eastern portion of Virginia understood fully that the ideology of delegates from the western regions were singularly devoted to obtaining state funding for roads and canals in their section of the state. It was not simply the fact that western regions believed that this funding was necessary, claimed Green, but it was the fact that the two sections of the state had moved to differing ideologies of governance from which cooperation was not feasible: "there is no such motive to restrain the attempts of those who have little common feeling with its possessors." 56 Green further asserted that the divisive interests of the two regions posed a direct threat to the status quo in Virginia, as it was well recognized that the white population of the western region stood poised to overtake the white population of the east. The statehouse was cautioned that the western region was prone to abuse of legislative power in order to achieve the means to fund the internal improvement projects that consumed West Virginia.

As a source of power for the forward movement of empire, America's European precursors to empire embraced technological advances as a way to advance their political and economic interests, while at the same time propelling a nation's progress forward. ${ }^{57}$ Not only was technology seen as indicative of the progress of a society, it was also used to set apart those who could be deemed inferior from those who favored the use of technology to advance the interests of empire. ${ }^{58}$ Michael Adas' analysis of European empire-building is applicable to an analysis of the ways that political power was transformative in an American society that increasingly depended upon technology to advance national interests. The mountaineers of West Virginia can be compared to those European workers who responded to the shifting power structure that accompanied industrialization, and modified their behavior to conform to industry standards and expectations. ${ }^{59}$ The relationship of superiority of eastern Virginia voices towards their western

\footnotetext{
55 Proceedings and Debates of the Virginia State Convention of 1829-30, 215.

${ }^{56}$ Ibid., 63.

57 Adas, 134.

${ }^{58}$ Ibid.,153.

${ }^{59}$ Ibid., 208.
} 
residents was long recognized, even from outside the state. The Genius of Liberty (Leesburg VA), addressed an article from Baltimore on March 6, 1827, noting that the Baltimore Patriot had accused them of inclinations of superiority and warning the public that the feelings of the general public could not be interpolated from the "vaunting resolutions adapted from time to time at Richmond." 60 Baltimore had alleged that the "voice of the people is seldom heard" in Virginia's decision-making, and that 'a few 'lords of the manor' are 'legitimates,' and their voice is heard and their vote taken," while the western voices were treated in the manner of feudal servants. ${ }^{61}$

As industrialists moved through West Virginia, there was an expectation that their values would become the values of the areas that were serving and fueling their industry, and an expectation that conformity to industry standards would prevail in order to support the interests of the industry, no matter the effect upon individualism. In the case of West Virginia, the independence and self-sufficiency of the subsistence farms were substituted piece by piece for the coal miner, the timber laborer, and the oil field worker - employment that serviced the industrialist and fueled a westward advancing empire, but did little to advance the individual republican interests of West Virginians. As men moved away from sustaining their families on individual farms and moved to employment in the extractive industries to support their families, their ability to separate themselves politically from the forces that controlled those extractive industries significantly diminished. The process of attrition by which the subsistence farmer operated within the framework of a society that relied upon barter and individual production to a society of wage workers dependent upon an income from a state or federally protected industry occurred over the span of many decades, but its roots rest within decisions made at statehood. Cook places the political blame for this shift at the feet of Alexander Hamilton, who believed that the westward expansion of the independent farmer was removing him from work in the production sectors that could provide both taxable revenue for the federal government and products for global trade. ${ }^{62}$ Ronald Lewis, who has done extensive work on the relationship between government and between post-bellum industrialism in West Virginia, defines this process as the transformation of "society

\footnotetext{
${ }^{60}$ Genius of Liberty, Volume 11, No., 9, March 6, 1827, accessed January 27, 2018 https://virginiachronicle.com/cgi-bin/virginia?a=d\&d=GL18270306.1.3\&srpos=26\&e=------182-en-20--21--txttxIN-wheeling------.

61 Ibid.

62 Cook, 62-63.
} 
through the aggregation, consolidation, and centralization of power in a national market system buttressed and protected by a new emphasis on property-oriented law and authority." $" 63$

Competing ideologies in Border States such as West Virginia also left those areas particularly vulnerable to influence from the power of persuasion, particularly by educated individuals who were able to utilize and perhaps manipulate the emotional response of a collective group of people in order to construct allegiance.

As emotional divergence demarcated sectional difference, Americans aligned themselves with 'North' and 'South.' These communities were never monolithic, but critics of the prevailing emotional standards tended also to dissent from aggressively sectional political movements, revealing how deeply intertwined emotion and ideology had become. ${ }^{64}$

This fostering of allegiance by drawing emotional connection and attention may be especially relevant in areas such as West Virginia, where slave ownership was not perceived as the sole issue driving the separation of ideologies. Francis Pierpont confirmed the same when he wrote to the editor of the Wheeling Intelligencer on March 16, 1859: "The great idea that I desire to impress upon the public mind is that there are other interests in Virginia than the negro interest." 65 When pressed upon the issue of Virginia's potential secession from the Union, Waitman Willey delivered a speech against secession, but cautioning the eastern representatives that they had long neglected their western counterparts. ${ }^{66}$ While Pierpont may have espoused political ideas that he believed motivated the common citizens, businessmen from across the country also expressed a vested interest in the state of affairs in West Virginia. In a letter from land broker, W. H. Tyler, who advised that he had "considerable land \& mortgage interests in Western Va.," Judge Gideon Camden was cautioned that it would be bad for the business of land speculation if the area failed to remain part of the Union: "under the Union \& Constitution, \& these administrators in the interests of white men, I am clear there will be such an impulse to business and values in your Country as has never been seen out of the United States." 67 In order for industrialists to expand their interests, they must be able to connect the citizens who work in that industry, who use that

\footnotetext{
63 Lewis, 6.

64 Woods, 3.

${ }^{65}$ Francis H. Pierpont to Archibald Campbell, March 16, 1859, letter, A\&M 14, Box 1, Folder 1, Archibald W. Campbell (1839-1899), Newspaperman, Papers (Morgantown, WV: WVRHC).

66 Willey speech.

${ }^{67}$ W. H. Tyler to Judge Gideon Camden, May 30, 1861, letter, A\&M 1188, folder 1, Gideon D. Camden (1805-1891) Papers (Morgantown, WV: WVRHC).
} 
industry, and who buy and trade with that industry to feel an alliance with the ideology that serves industry. The ability of industrialists to highlight emotional connections that the advantages of industry is exponentially heightened through the use of political campaigns, newspaper articles and careful management of local political office appointments. Connecting the local to industry is most effective if the industrialist and the politician can convince the citizenry that becoming a part of a particular industry is a route to self-sufficiency and independence in its own way.

As historians continue to examine the role that capitalism had on political ideologies during the Civil War era, it is possible to focus on the transitional spaces such as West Virginia, where large-scale manufacturing was not a particular force. While the large scale mills of New England were not yet in West Virginia, what is critical is the influence that industry and capitalism had as they moved through the state and extracted the natural resource of the state in furtherance of the larger corporate need resulted from a place of privilege in the state's government structure. The ideology of a national force of industry such as the B\&O Railroad can be contrasted with the regional industry of the Kanawha Valley salt businesses to explore the differences between the ways that the arm of industry that reaches across state borders can completely transform geographic areas. What is evident in border areas such as West Virginia is that the existence of large-scale manufacturing was not necessary to the cultivation of an ideology rooted in industrial expansion. The promise of potential wealth rooted in extraction of natural resources and cooperation and alliance with industries associated with westward expansion moved West Virginia's ideology away from an eastern society they found stagnant.

The American bourgeoisie thus acted like revolutionary classes throughout modern history, both in its struggle to gain a measure of control over the chaos born of its own success, and the willingness to destroy parts of itself in doing so. ${ }^{68}$

While capitalism, in respect to the pursuit of wealth through buying and selling, can be a powerful mechanism of change, it is equally important to consider the societal changes that occur when capitalism becomes a process of an identity and an ideology. Steven Stoll posits that the transformation of a society to a dependence upon and ideological identification with the process of capitalism results in the process by which: "Tens of millions of people link their identities, the trajectory and meaning of their lives, to a social system with all sorts of destructive tendencies,

\footnotetext{
${ }^{68}$ Michael Zakim and Gary J. Kornblith, ed., Capitalism Takes Command: The Social Transformation of Nineteenth-Century America (Chicago: The University of Chicago Press, 2012), 4.
} 
associating it with the highest aims of society itself." ${ }^{69}$ This is precisely what we see in West Virginia, with the body of men who designed and profited from West Virginia's foundation, and with the transformation of small communities who adhered to the national movement to an ideology of industrial progress. The voices and influence of the industrialists and politicians who shaped West Virginia's statehood and crafted the formative legislative documents that opened the region for business to large industrial concerns will be addressed next.

${ }^{69}$ Stoll, 29. 


\section{CHAPTER THREE: Ideology Becomes Influence}

The power of a political ideology is rooted in the intent to exert power to achieve a common goal. John Stealey III argues that there is little to suggest that important industrial players of early West Virginia shared a common goal based upon their personal interests, instead focusing on political differences. ${ }^{1}$ John Alexander Williams, however, in his 1967 PhD Dissertation and analysis of the lives of Henry Gassaway Davis and Stephen Elkins, introduces his subjects with the theory that "divisions among businessmen, while often a factor in public policy decisions, were less significant than the underlying political unity of big business interests against rival interest groups."2 Williams later expanded his study of Davis and Elkins to include a wider range of industrialists in West Virginia post-Civil War who operated within "a territory almost wholly subject to the social impact of extractive industry resulted in a phenomenon best described as a colonial political economy." 3 This chapter seeks to broaden the understanding of the pervasive presence of several men who were devoted to such a political economy exerted on the statehood process, and includes familial and business ties that linked them closely in order to illustrate the enormous influence that a small group of men, particularly those connected to the larger industrial empire of the $\mathrm{B} \& \mathrm{O}$, had upon the statehood process. The influence these men and their devotion to an ideology of industry had upon the WV statehood process is a reflection of the definition of oligarchy held by John Adams. According to Luke Mayville, Adams drew upon political theories of Machiavelli to formulate his theory that rules who were "corrupt, self-serving, and grasping for power" were best described as an oligarchy. ${ }^{4}$ Several key players in West Virginia's formation and formative years fit within the parameters of oligarchy, including Peter Van Winkle, Johnson Camden, and Henry Gassaway Davis, all of whom were instrumental in creating a favorable political environment for the implementation of wealth extraction by forces inside and outside the state.

\footnotetext{
${ }^{1}$ Stealey, West Virginia's Civil War-Era Constitution, 22-23.

${ }^{2}$ Williams, Davis and Elkins of West Virginia, introduction page.

${ }^{3}$ Williams, West Virginia and the Captains of Industry, 1.

${ }^{4}$ Mayville, 42.
} 
The antebellum, Civil War, and post-bellum industrialists who shaped West Virginia were linked in "networks of local and regional influence in subtle but far reaching ways." because these men were linked across the region that became West Virginia in both familial and business spheres, their very presence in the politics of statehood offered a sense of foundation to the voters who aligned with their brand of ideology. Williams opines that these men "lent to the competitive stirring of early Appalachian capitalism the stability of extended families and cohesive communities." 6 The cohesiveness of communities was, however, more emblematic of a façade of collectiveness in search of a state free from Virginia's politics. The stirrings were real, the capitalism was real, but the glue that held these men together was personal wealth and desire for political advancement.

This chapter will examine the overlapping political and economic concerns that were critically important to many important statehood political figures both prior to and immediately following the actual separation of West Virginia from Virginia. These men were heavily invested in real estate speculation in areas that later became prime locations for the outsourcing and extraction of resource wealth from the state. The legislative influence of these men at varying times in the political formation of the state is also critical, and points to the particular influence that industry had on the statehood formation process. The importance of the ways these men moved within the business and political world of West Virginia is not, however, their individual or collective success in the world of big business. What is important to understand is that these men were part of the larger movement of westward empire and, as John Williams explains: “[t]hey merely translated into local reality broader more impersonal forces that ultimately were rooted in the natural environment of West Virginia and in the national economic system within which the state's industrialization took place." 7 The influence of men who espoused an ideology of industry, can be contrasted with the Kanawha Valley salt industry, which did not rise to the level of influence that the railroad and oil/gas industries projected upon statehood. Finally, this chapter will examine the ways that industrial influence overshadowed the economic trajectory of the common man in West Virginia.

\footnotetext{
5 Williams, Davis and Elkins, 221.

6 Ibid..

7 Williams, Captains of Industry, 172.
} 
The influence that was exerted by politicians who were working to support the interests of national business concerns versus politicians who were involved with industries that remained more regionalized is illustrated by the Ruffner family of the Kanawha salt industry. The Kanawha salt industry, while trading on a large scale outside of its immediate geographic area, maintained a connection to the local that separates it from other industries such as the railroad, whose interests were simply not in line with those of West Virginians. As John Stealey III points out, the Kanawha Valley salt producers were indeed capitalists, but these capitalists were not part of the national wave of empire that industries such as the railroad industry were, and the depth of their political connections were different. One of the primary differences that can be seen when comparing the Kanawha salt industry to industries such as the railroad industry is the degree to which the state government remained involved in the creation of chartered businesses within its borders. ${ }^{8}$ The free-form competition encouraged by the partnership methods of business typical of the salt industry are clearly countered by the state-sanctioned charters that allowed corporations such as the Northwestern Virginia Railroad (an adjunct to the B\&O Railroad) to assert their interests with the force of the government behind them.

Ruffner salt interests in the Kanawha Valley pre-date the nineteenth century, when Joseph Ruffner Sr. moved to the area from the Shenandoah Valley area of eastern Virginia. ${ }^{9}$ After several years of legal contests concerning faulty contracts, and after years of technological trial and error, by 1810 the Kanawha Valley was home to a variety of independent salt companies whose production was unmatched nationally. ${ }^{10}$ Salt became a huge national industry by virtue of the ever-expanding western markets, and the area became inviting to capitalists who sought quick investment opportunities. Christopher Phillips notes that the salt industry in the Kanawha Valley and the Midwest actually worked against the government, rather than with it, in a highly competitive market that did not achieve the large scale ideological changes that industries such as the railroad were able to achieve. ${ }^{11}$ Several local producers, including the Ruffners, consolidated their interests, creating a business model that pre-dated the modern pool, and set a practice by which they "functioned as a copartnership that manufactured on its own, controlled production of

\footnotetext{
${ }^{8}$ Stealey, The Antebellum Kanawha Salt Business and Western Markets, 194-195.

${ }^{9}$ Ibid., 9.

${ }^{10}$ Ibid., 16.

${ }^{11}$ Christopher Phillips, The Rivers Ran Backward: The Civil War and the Remaking of the American Middle Border (New York: Oxford University Press, 2016), 17.
} 
its members, and acted as a central sales agency." 12 The insular nature of the small industry created legal problems, even among members of the same family, as evidenced by the complex lawsuit filed by Henry and Lewis Ruffner against their brother-in-law, Richard Putney in $1845 .{ }^{13}$ The family was not only intimately tied to each other and to their combined salt production interests, but the family business interests were also subject to "the precarious character and fluctuation of the markets," to such a degree that inherited property and family cooperative business interests became hotly disputed. ${ }^{14}$ Not immune to the problem of lack of good transportation options and desirous of expanding beyond the salt industry, the Ruffner family, along with many others, submitted a petition to the Virginia legislature in 1859, demanding that "consistent roads and railroads" be given priority for Kanawha County. ${ }^{15}$ The partnership arrangements within the salt industry in Kanawha County were important business innovations, setting the stage for future cooperative business arrangements, but could not sustain a national position when more westward markets opened up and westward saline sources were located to service those western markets. The salt industry required individual producers to adhere to business practices agreed upon by the collective, including rates of production and sales costs that were simply not available to those operating within the larger industrial needs of companies such as the B\&O Railroad. Because the salt industry also remained largely dependent upon slave labor, its interests were less aligned with northern attitudes of cheap, waged labor for production. ${ }^{16}$

Lewis Ruffner served in the Virginia legislature in 1825, and later represented Kanawha County in the Second Wheeling Convention, in the session of the reorganized government of Virginia (in Wheeling), and in the first two WV legislatures. ${ }^{17}$ Kanawha County, home to the largest saline interests in the state, continued to be actively interested in the issue of representation apportionment, as evidenced by reports in the Parkersburg Gazette on January 13, 1842, noting that citizens of Kanawha County were among several counties cautioning the Virginia assembly

\footnotetext{
12 Stealey, The Antebellum Kanawha Salt Business and Western Markets, 22.

${ }^{13}$ Henry and Lewis Ruffner v. Richard E. Putney, Lewisburg Court of Appeals 1841-1843, MS 79-83, Box 5 (Charleston, WV: West Virginia State Archives (WVSA)).

14 Ibid..

15 "Kanawha County Petition, December 7, 1859," Legislative Petitions Digital Collection, Library of Virginia, Richmond VA, accessed February 20, 2018, http://digitooll.lva.lib.va.us.

16 Phillips, 17.

17 Charles H. Ambler, Frances Haney, and William B. Mathews, ed. Debates and Proceedings of the First Constitutional Convention of West Virginia (1861-1863) (Huntington, WV: Gentry Brothers, Printers, 1863), 88-89.
} 
that the western portions were becoming increasingly united. ${ }^{18}$ Writing from Wheeling in February, 1864, Ruffner expressed disgust at a proposed inspection law that would affect the salt industry, noting that competition amongst producers had created such an adverse atmosphere that it was now bleeding into the legislative process - a mechanism that Ruffner disavowed: "No one man should be allowed to retain the power to ruin a community through mere distrust of the integrity of his fellows." 19 As a vigorous businessman, however, Ruffner did not limit himself to interests within West Virginia, as evidenced by his lengthy period of residence in Louisville, Kentucky, where he largely conducted his land ventures and salt production businesses through the proxy of a Kanawha County, Virginia attorney. ${ }^{20}$ Business dealings were conducted by Ruffner from Nashville to Cincinnati, and he often dealt with bacon purchases, as well as salt sales. $^{21}$ Keeping a close eye on the bottom line was clearly important to Ruffner, who advised his attorney to attempt to persuade stockholders in his business to vote to dissolve in 1852 , as the chronic fluctuations in the market made the business unstable. ${ }^{22}$ Ruffner's voice is silent during the first Constitutional Convention of West Virginia, indicative of the more powerful voice of the nationalized industries whose voices and needs were central to the statehood movement, notably the voice of the railroad industry that was embodied by Peter Van Winkle.

\footnotetext{
18 "Reapportionment of Representation," Parkersburg Gazette, January 13, 1842. Microfilm Collection, WVU WVRHC, Morgantown, WV.

${ }^{19}$ Lewis Ruffner to N.B. Coleman, February 25, 1864, letter. Nelson B. Coleman Papers Correspondence A-L, MS 79-8 (Charleston, WV: WVSA).

${ }^{20}$ Lewis Ruffner to B.S. Smithers, May 5, 1852, letter, Lewis Ruffner Collection, MS 80-212 (Charleston, WV: WVSA).

${ }^{21}$ Lewis Ruffner to B. S. Smithers, July 1, 1851, letter, Lewis Ruffner Collection, MS 80-212 (Charleston, WV: WVSA).

${ }^{22}$ Lewis Ruffner to B.S. Smithers, Oct. 25, 1852, letter, Lewis Ruffner Collection, MS 80-212 (Charleston, WV: WVSA).
} 


\section{$\underline{\text { Peter Van Winkle }}$}

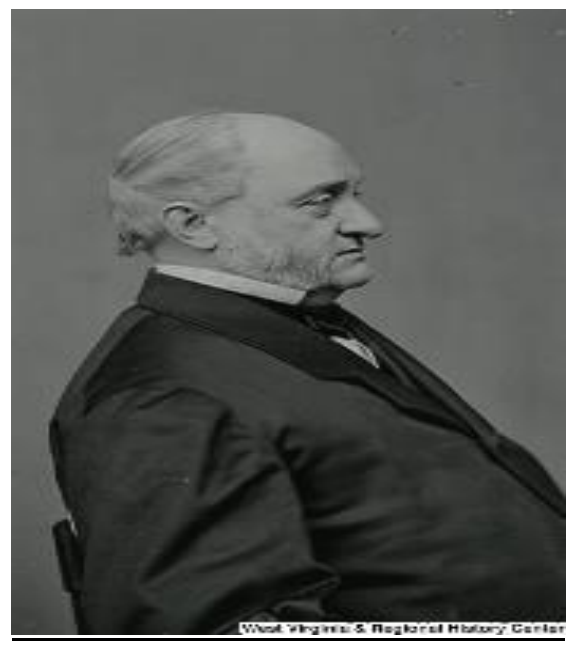

Figure 2: $\quad$ Peter Godwin Van Winkle, circa 1864 West Virginia History OnView West Virginia and Regional History Collection West Virginia University Libraries

Peter Van Winkle held a front row, center seat for the crafting of the legislation that shaped the state of West Virginia. As a railroad booster and attorney, Van Winkle was hardly representative of the ideology of the farmer, and was astute at the management of industrial interests. With a lengthy history of inspiring communities to rally behind bond proposals for railroads, Van Winkle was the ultimate showman in the realm of the political. Writing from Parkersburg in 1836, Van Winkle enticed the B\&O Railroad that "[w]e believe that in this pint of view Parkersburg is unexcelled, it is certainly without the disadvantages of rival works cherished by the local authorities and commanding the good wishes of its citizens." ${ }^{23}$ Van Winkle fully intended to lure the B\&O through West Virginia, despite his reputation of holding out for the best interests of the people. In his letter to the committee of townspeople in Parkersburg regarding their attempts to raise bonds for the B\&O project, Van Winkle advised that the town should carefully consider the issue of taxation of "non-resident bondholders,": "It makes no difference to the Town, under the present laws of Virginia, as you are aware that no such tax, can be levied by

\footnotetext{
${ }^{23}$ Peter Van Winkle to John W. Garrett, President of the B\&O Railroad, November 12, 1836, letter, Peter Godwin Van Winkle (1808-1872) Papers, A\&M 136 (Morgantown, WV: WVRHC).
} 
state, county, or town. It is not likely that the policy of the State in this respect will change" 24 Van Winkle would, in less than ten years, of course, see the policies shift dramatically, as West Virginia was born and power shifted rapidly in the early years of statehood.

Van Winkle's links to the paterfamilias of West Virginia's political elite began early. Following his early education and marriage to Julia Rathbone, Van Winkle studied law and later partnered with General John J. Jackson, a formidable figure in politics both before and after the split of Virginia. ${ }^{25}$ His residence in the then-small town of Parkersburg spurred Van Winkle to numerous ideas for the advancement of the town, which he coordinated with his own drive for personal investment. Like many of his contemporaries, Van Winkle not only bought and sold real estate in the manner with which most are familiar, but his exposure to inside knowledge of "delinquent and forfeited lands" provided ample opportunity to turn knowledge into cash or investment potential. ${ }^{26}$ John Alexander Williams identifies the practice of land speculation as particularly welcoming to attorneys, whose profession took them into isolated rural counties with low literacy rates at a time when the complex land transfer system of Virginia was ripe for collecting lands. ${ }^{27}$

Van Winkle's political concerns were consistently devoted to preserving the route for business and industrial interests, and do not align him with any pro-Union cause related to the abolition of slavery. Colonization projects were part of the Van Winkle political lexicon, and he published a lengthy article advocating the same in the Parkersburg Gazette on October 4, 1843, in his capacity as a member of the executive committee of the Colonization Society of Wood County. ${ }^{28}$ The Society touted itself as "extending civilization and the gospel, hand in hand," as they moved the creation of a free society in Africa to serve as the "most effectual means for suppressing the horrors of the American slave trade."29 Van Winkle also noted, however, that slavery was simply an irresponsible use of available capital, suggesting that the money spent on slaves could be "transferred to manufacturing and commercial enterprises. This unprofitable

\footnotetext{
${ }^{24}$ Peter Van Winkle to George O. Welles and others of the Committee of Council, October 12, 1855, letter, Peter Godwin Van Winkle (1808-1872), Letter and Receipt for Stock, A\&M 142 (Morgantown, WV: WVRHC).

${ }^{25}$ Evert F. Whitener, A.B., "Peter Godwin Van Winkle" (MA Thesis, WVU, 1929), published in Morgantown, WV, $1946,2$.

${ }^{26}$ Ibid., 3.

${ }^{27}$ Williams "Politics," 217.

${ }^{28}$ P.G.Van Winkle, "Colonization," Parkersburg Gazette, October 4, 1843. Microfilm Collection, WVU WVRHC, Morgantown, WV.

${ }^{29}$ Ibid..
} 
investment of capital is, I apprehend, the true reason why the southern states do not advance so rapidly in population and wealth." 30

Internal improvements were a large concern for Van Winkle, who notably became more actively involved in railroad ventures following his representation in the Virginia Constitutional Convention of $1850 .{ }^{31}$ It did not escape the sharp eyes of Van Winkle that the western delegation was increasingly adamant about obtaining relief from their isolation from commercial and travel opportunities railroad lines could provide. Van Winkle and several others advertised in prominent elections, cautioning "the Voters of Wood and Ritchie Counties" in 1844 to strongly consider that the most important issue in a legislative election was which candidate would "advocate our claims in the next legislature," namely the need to obtain the terminus of the B\&O Railroad. ${ }^{32}$ The personal ventures into railroad construction, the commercial opportunities a line could provide his beloved town of Parkersburg, and the genuine belief that railroads held the best hope for the viability of West Virginia were not, however, Van Winkle's sole motivation. The Northwestern Virginia Railway Company (NVRC) was granted a charter by the state of Virginia in 1851, but this company was little more than a shell company to provide access to the larger entity of empire, the B\&O. ${ }^{33}$ While the road was devised as a public/private partnership with the city of Parkersburg, "[o]ver ninety-eight percent of the financial backing came from outside the state." 34 It is one thing to offer a plan for the best interests of a particular place (Parkersburg) or a particular region (West Virginia), but it is another thing entirely to remain uninfluenced by the controlling interests of this enterprise. Van Winkle's role in the NVRC became more visible at the critical period just prior to the statehood movement. Taking over the presidency of the NVRC in 1857, a position which Van Winkle held through 1870, allowed him time to accomplish such favorable actions as constructing a method by which the rail line along the Little Kanawha River was transferred to the city of Parkersburg free from taxation. ${ }^{35}$ While, on the surface, the issue of taxation of a small regional line seems insignificant, the line was implicitly part of the larger $\mathrm{B} \& \mathrm{O}$ line, which afforded the $\mathrm{B} \& \mathrm{O}$ the type of easy access through Virginia it had long desired. The

\footnotetext{
30 Van Winkle, “Colonization."

31 Whitener, 8.

32 Henry Steed, et. al., "To the Voters of Wood and Ritchie Counties," Parkersburg Gazette, April $25,1844$. Microfilm Collection, WVU WVRHC, Morgantown, WV.

33 Whitener, 10.

34 Ibid., 11.

35 Ibid., 11-12.
} 
hand-in-glove participation of men like Van Winkle facilitated the movement of the B\&O through West Virginia. "Van Winkle had for some time represented the Baltimore and Ohio Railroad Company at various sessions of the legislature, and as late as 1860 he was representing John W. Garrett, president of that company, at the session of the legislature then meeting in Richmond."36

Van Winkle's experience of using legislative practice to construct favorable business environments, the intimate knowledge through the practice of law of available tracts of land, and the invaluable business connections that Van Winkle gained made him more than just a legislator or an entrepreneur. Van Winkle was one of the several hands that actively shaped the creation of West Virginia through an ideology that clearly intended to use the power of government to push economic agendas that contributed to the personal success of the legislator. It is likely that Van Winkle's connection to the $\mathrm{B} \& \mathrm{O}$ and the formation of the state of West Virginia was intimately tied to the highest office in the land, as Van Winkle's relationship with the B\&O reached as far as contributing his opinion upon the issue of the Constitutionality of the admittance of West Virginia to the United States.

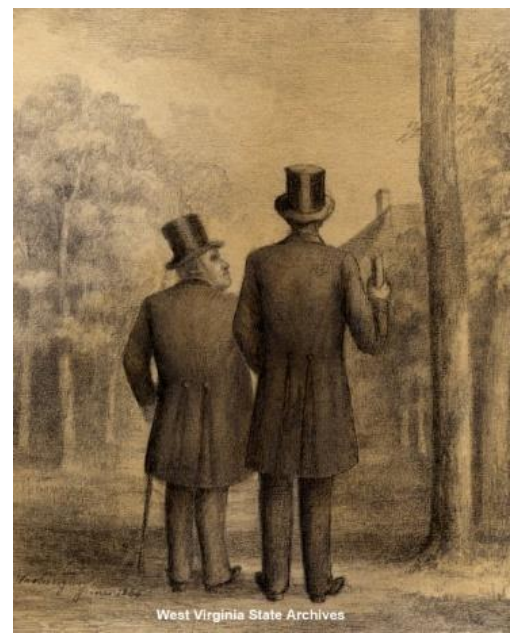

Figure 3: $\quad$ Abraham Lincoln and Peter G. Van Winkle drawing by Joseph H. Diss Debar showing the president walking and discussing West Virginia affairs with Senator Van Winkle, June 1864. Diss Debar Collection.

West Virginia State Archives. http://www.wvculture.org/history/gallery/sthd/sthd43.html.

Van Winkle corresponded directly with B\&O President Garrett's office throughout the 1860 s, sending him newspaper columns and articles relative to the constitutionality of the formation of the state of West Virginia and, specifically, the inclusion of the counties of Berkley

\footnotetext{
${ }^{36}$ Whitener, 9.
} 
and Jefferson. ${ }^{37}$ Garrett, in turn, discussed the constitutionality of the issue with the Secretary of War, later asking for additional legal advice concerning his company's route through Berkeley and Jefferson counties, specifically whether or not the state of Virginia could "reclaim" the counties. ${ }^{38}$ Following West Virginia's official statehood, Van Winkle was elected US Senator for West Virginia in 1863, and Garrett kept a finger on the pulse of West Virginia legislative proceedings after statehood, planting B. Despard at the Wheeling statehouse in 1866 to monitor legislation concerning taxation of the railroad. ${ }^{39}$

The most critical place in the history of Peter Van Winkle, in terms of West Virginia's statehood is seen in the influence he exerted during the Constitutional Convention proceedings. Van Winkle espoused a belief that eastern views had long retarded the expansion and success of West Virginia: "Van Winkle warned that deep political differences of opinion always existed in Virginia. Virginia had since Jefferson's time been going backward with oppressive legislation. Eastern Virginians had adapted legislation to their depressed situation and condition, not to the west's hope for progress." 40 Van Winkle continued to be a proponent of internal improvements, but worked to ensure that private enterprises such as the B\&O could efficiently operate within and through the new state of West Virginia without creating an undue tax burden on the state. ${ }^{41}$

Van Winkle not only influenced the statehood movement through his personal and business relationships, he was also directly tied to other prominent state-makers, including Johnson Newlon Camden, to whom Van Winkle's son Godwin felt close enough to regularly request both direct loans and business advice. Godwin Van Winkle embraced his father's ideology of commercial opportunities through western expansion, advising Camden that, as collateral for substantial loan, Godwin Van Winkle had expectations of rapid repayment through the prospect of cattle ranching in Texas. ${ }^{42}$ Johnson Camden is perhaps the least recognizable figure in West Virginia's early political history, but perhaps the most emblematic of the power of ideology.

\footnotetext{
37 P.G. Van Winkle to Andrew Anderson, Esq., September 20, 1865, letter, 1861-1865 West Virginia, 16.1.4, 28 MS 2003, 383 (Baltimore, MD: Hays T. Watkins Research Library of the B\&O Railroad Museum Archives (HWRL).

38 John W. Garrett to C.J.M., August 10, 1865, letter, 1861-1865 West Virginia, 16.1.4, 28 MS 2003, 383 (Baltimore, MD: Hays T. Watkins Research Library of the B\&O Railroad Museum Archives (HWRL).

${ }^{39}$ B. Despard to John W. Garrett, February 25, 1866, telegraph, 1861-1865 West Virginia, 16.1.4, 28 MS 2003,383

(Baltimore, MD: Hays T. Watkins Research Library of the B\&O Railroad Museum Archives (HWRL).

40 Stealey, Convention, 75.

41 Ibid., 86.

${ }^{42}$ Godwin Van Winkle to Johnson Newlon Camden, June 2, 1877, letter, Johnson Newlon Camden (1828-1908) Papers, A\&M 7, Box 1 (Morgantown, WV: WVRHC).
} 


\section{JOHNSON NEWLON CAMDEN}

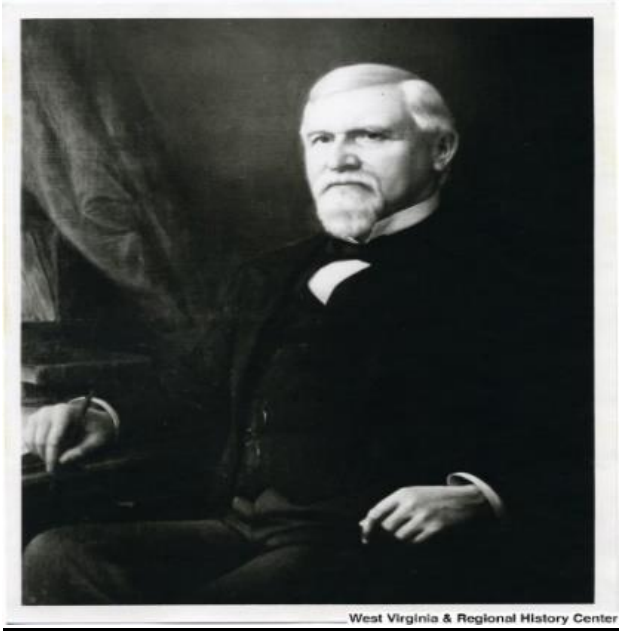

Figure 4: Johnson N. Camden

West Virginia History OnView, West Virginia and Regional History Collection West Virginia University Libraries

Johnson Newlon Camden's most recognizable influence has long been known in terms of his post-bellum political and business activities, including his position as a United States Senator from the state of West Virginia in the 1870s. While his later business ventures with the Standard Oil Company are also known by West Virginia historians, his heavy influence is not widely known by the public, and it is important to examine the foundations of that influence that were lain from the 1840 s through the 1860 s. Camden's deft navigation through the worlds of law, politics, and business made him a quiet, yet formidable figure in the events that led up to the creation of the state of West Virginia. Camden began his voyage into influence at the young age of 14, when he was assigned to work as an assistant in the county clerk's office of Lewis County, Virginia, where his family had connections. ${ }^{43}$ At age 16, Camden was sent to attend the Northwestern Academy in Clarksburg VA, where his uncle, Judge Gideon Camden served on the board of directors, along with George Lee and Waldo Goff. ${ }^{44}$ The principal at Academy at the time was Gordon Battelle, who was a prominent figure in the West Virginia statehood movement and a college classmate of

\footnotetext{
${ }^{43}$ Festus P. Summers, Johnson Newlon Camden: A Study in Individualism (New York: G.P. Putnam's Sons, 1937), 32.

${ }^{44}$ Petition of George H. Lee, Waldo P. Goff, and Gideon D. Camden, Legislative Petitions of the General Assembly, 1776-1865, Accession Number 36121, Box 113, Folder 33; December 18, 1844. Legislative Petitions Digital Collection, Library of Virginia, Richmond, Va., accessed February 15, 2018, http://digitooll.lva.lib.va.us.
} 
Francis Pierpont, another prominent figure in the statehood movement. ${ }^{45}$ While certainly educationally sufficient, Camden did not pursue college, instead returning to his parent's place of residence in Braxton County, Virginia, where he again found himself in the employ of the county, serving as a deputy of the county court. After a short and unsuccessful stint at West Point, Camden returned to West Virginia to read law, and was admitted to the bar in Braxton County in 1850, where he engaged in both a small private practice and worked for a period as the county prosecutor. ${ }^{46}$ Working with a maternal uncle on a survey project provided Camden with the opportunity to obtain access to information concerning lands subject for investment pursuant to a longstanding practice in Virginia:

For years the system employed for entering, locating, and granting the unappropriated lands of the commonwealth had involved Virginia in interminable difficulties and embarrassments. A large portion of her public domain lying west of the Alleghenies had been granted in large tracts to speculators and adventurers, who had not only neglected their holdings and failed to pay the taxes thereon but who had also in many instances never entered them on the land books for assessment as required by law. ${ }^{47}$

Virginia found the failure to record a significant source of loss of revenue, as the unrecorded land resulted in a loss of taxable income and, with legislation in 1831, a system was devised by which "unless lands were entered on the commissioner's books and the taxes paid within prescribed periods, the titles should become forfeited and vest in the commonwealth."48 Land speculation drew less than scrupulous figures into the western regions to negotiate land deals, which did not go unnoticed by some observant citizens. The Parkersburg Gazette on December 17, 1842 included a caution against on H.O. Middleton, who was operating under the auspices of the North American Land Company and who stood accused of fraudulently obtaining land from the estate of one Robert Morris. ${ }^{49}$ Mr. Middleton inserted his own column next to the caution, advising the public that his methods were wholly legal. ${ }^{50}$ By 1846, Virginia statutes had again been modified

\footnotetext{
45 Summers, 34-35.; also see Ambler, Convention, 60-61.

46 “Johnson Newlon Camden,” Parkersburg Sentinel, April 25, 1908 (obituary of Johnson Newlon Camden), accessed March 31, 2018, www.wvculture.org/history/businessandindustry/camdenjohnson02.html.

47 Summers, 43.

48 Ibid..

49 “To the Public," Parkersburg Gazette, December 17, 1842. Microfilm Collection, WVU WVRHC, Morgantown, WV.

50 “Timely Caution," Parkersburg Gazette, December 17, 1842. Microfilm Collection, WVU WVRHC, Morgantown, WV.
} 
to provide that local, county courts could put delinquent lands up for sale and provide deeds to the same from the county office. It was through this system that Camden, among others, took advantage of "a wave of land speculation, the repercussions of which are felt in West Virginia even at this late date." ${ }^{51}$ Camden, for instance, was able to purchase a massive tract of land consisting of 4,951 acres at a public auction in Braxton County, for the meager sum of $\$ 611$, less than one dollar per acre. ${ }^{52}$ In 1850, during which Camden was taxed for more than 2,000 acres of land, Josias Adams fell delinquent for taxes due on more than 15,000 acres of land and Henry Middleton fell delinquent for taxes on in excess of 250,000 acres of land. ${ }^{53}$ Stoll points to the ability to use land for the production of wealth is critical to the transformation of a society to move toward a capitalistic society:

Capital moved differently. It acted through individuals and institutions. It employed impersonal laws and the language of progress. Mountain people knew how to soldier and to hunt, to tract and animal or an enemy through the woods. But few of them could organize an act of the legislature or to stop a clear-cut. The scramble built upon these vulnerabilities, but it did not happen all at once. The first thing it required was a conversion in the ownership and uses of land. ${ }^{54}$

Here, Camden was a magician. Through his early exposure to the functional mechanism by which property could be easily and in a relatively obscure manner acquired, moving on to his period of building and expanding incorporated entities and business relationships through which to extract and move capital, and finally through his political career that was clearly designed to craft and steer legislation in such a way that his personal wealth and the wealth of his colleagues could be increased, Davis was the definition of capitalism and empire.

Wilma Dunaway points to the use and appropriation of land as one of the first steps to moving a rural area into the global capitalist experience, whereby the physical land was transferred to paper (by deed, grant and etc.), that could then be bought and sold but, more importantly, whose use could be manipulated for wealth accumulation by virtue of its transient paper existence. ${ }^{55}$

\footnotetext{
51 Summers, 44.

52 Braxton County, West Virginia Deed Book 9, page 47-49, land of the Hudson Martin heirs that had gone delinquent for taxes in 1855,1856 , and 1857.

53 Ibid..

54 Stoll, 131.

${ }^{55}$ Dunaway, 277.
} 
"Consequently, the regional environment was subordinated to the drives of the capitalist world economy in such a way that more wealth from trading in the region's land resources accumulated in other zones than in Southern Appalachia." examination or through communications from his contacts in small rural courthouses in central West Virginia) ascertain deficiencies in land deeds and delinquencies of tax payments upon those lands resulted in his acquisition of vast expanses of land valuable for wealth extraction.

By the early 1850s, Camden was well-versed in the pattern of land use, appropriation, and availability that would anchor his future personal empire, and he moved on to the equivalent of graduate school for industrialists - training in finance. With an eye ever-forward facing, Camden next set his sights back to his familial roots of Lewis County, just north of his Braxton County law practice. While the private practice of law had provided some minor experience, Camden realized that internal improvements in the form of the newly opened Weston and Gauley Bridge Turnpike had opened doors for commercial opportunities at the Lewis County town of Weston. ${ }^{57}$ In 1853 , at the age of 25, Camden accepted the position of cashier's clerk at the Weston branch of the Exchange Bank of Virginia, and he was working at this job when the Northwestern Virginia Railroad Company (NVRC) selected the branch as one of its designated financial institutions during important construction of the line that ultimately became the $\mathrm{B} \& \mathrm{O}^{58}$ This depository relationship placed Camden within the direct orbit of Peter Van Winkle, president of the NVRC, and further introduced him to the interaction between the enterprises of West Virginia business interests and the growing national reach of the $\mathrm{B} \& \mathrm{O}$ Railroad. The connections that Camden and Van Winkle shared with the Weston Branch of the Exchange Bank of Weston place them directly near the scene of the commandeering of more than twenty-thousand dollars in gold, which was taken from the Exchange Bank in July 1861 by Union troops under the direction of General George McClellan, with that gold then being "safely deposited in the Northwestern Bank, and will be used by those to whom it truly belongs - the true State government."

Ties to Parkersburg also held Van Winkle and Camden in close connection, with Camden serving as President of the First National Bank of Parkersburg in $1862 .{ }^{60}$ An unidentified

\footnotetext{
${ }^{56}$ Dunaway, 277.

57 Summers, 52.

58 Summers, 52-55.

${ }^{59}$ Wheeling Intelligencer, July 3, 1861. Van Winkle is known to have worked directly with Francis Pierpont to gather funding for the new state.

60 Parkersburg Sentinel, April 25, 1908. Microfilm Collection, WVU WVRHC, Morgantown, WV.
} 
newspaper fragment found among Camden's personal papers confirms that, even to his contemporaries, Camden's business dealings were not always well-respected, and the author suggested that: "[i]t may not be out of place to suggest that the bank examiner drop in some day," intimating that Camden was diverting stockholder monies to "the Camden Consolidated Oil

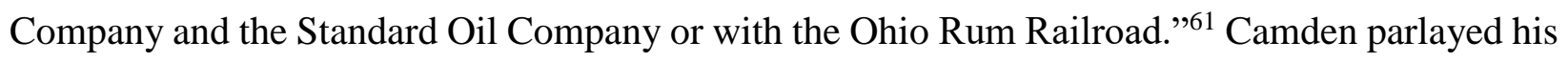
legal knowledge into the business of collections throughout several counties in what is now West Virginia, and he "was attorney for several of the larger Baltimore wholesale and jobbing houses that enjoyed a practical monopoly of sales in this part of western Virginia."62 A pattern was being constructed at the feet of Camden: both the structure and the deficits of the law can provide business opportunities; large corporations can provide a steady stream of work and income for diligent representatives who do not question the underlying monopoly intent of those corporations; and, the opportunity for intersection between the law and big business was wide open in West Virginia. Camden's increasing knowledge of the ways that business could utilize the law to advance its interests happened at the tipping point of the internal improvement argument in Virginia. Access to land became the clarion call for Camden, who had gathered sufficient skill in his first ten years of employment to begin the process of gathering the foundation of his own empire. The knowledge he gained as a young adult working within small county courthouses, the knowledge and access he gained to lending practices of small financial institutions, and the handson information he gathered regarding natural resources positioned Camden to engage fully in wealth extraction. ${ }^{63}$

Wilma Dunaway notes absentee land ownership as contributory to the poverty-stricken conditions of Appalachia throughout the antebellum period, and further notes that capitalists holding such absentee land often politically negotiated ways to obtain public financing for internal improvements to advance their own business interests. ${ }^{64}$ Camden's foray into land speculation expanded until, by 1858, in Braxton County alone, he had amassed more than twenty thousand acres in a partnership with G.W. Byrne, and also included land in Wirt County, where he would

\footnotetext{
${ }^{61}$ Newspaper fragment, appearing to have been torn from a newspaper, undated and writer unidentified. Johnson Newlon Camden Collection, A\&M 7, Box 59, "Coal \& Coke, Oil, Electric Railways, WV Improvements,” Folder No. "A" (Morgantown, WV: WVRHC).

62 Summers, 56.

63 Ibid., 56-57.

${ }^{64}$ Dunaway, 74.
} 
begin to develop the oil business that would launch him into the world of global business. ${ }^{65} \mathrm{~A}$ particular tract commonly referred to as the "Caperton tract" offers an intriguing peek into the opportunities that were open to less than scrupulous businessmen in West Virginia. In 1884, Camden enlisted the services of his partner, Charleston attorney Byrne, who provided Camden with a legal abstract of the status of the history of purchases of several tracts of land in Webster County, collectively called the Caperton tract, as the heirs of Allen T. Caperton eventually brought suit on the matter. ${ }^{66}$ Byrne advised Camden that a "company of gentlemen," who included a John Shreve and a Benjamin Rich, were responsible for fraudulently causing "700,000 acres of land to be entered on the land books for taxation."67 The US Supreme Court case of Rich v. Braxton confirms that there "was a fraudulent contrivance to overcome the inherent difficulties that were in the way of sustaining the sale of 1869 for the taxes of $1868 .^{68}$ The issue of the transfer of land carried on for more than three decades, with additional suits being brought concerning "land containing 90,705 acres" that had been sold to Camden by special commissioner sale in $1885 .{ }^{69}$ Caperton himself sued concerning the purchase of the Caperton lands. ${ }^{70}$

Camden's practice of utilizing the knowledge stream of the local courthouse system was not novel, and can be traced back to the revolutionary concept of calculation of future value of available land developed by Sir William Petty in England during the seventeenth century. Most significant to Petty's process was the idea that those who owned land were due a portion of its worth in the same way that those who worked the land were due. ${ }^{71}$ The transformation of land

\footnotetext{
65 Summers, 67.

${ }^{66}$ George Byrne, abstract of deed/title to the Caperton lands, February 18, 1884. Johnson Newlon Camden Collection, A\&M 7, Box 67, "Real Estate September 30, 1852 to January 8, 1904," File “B," (Morgantown, WV: WVU WVRHC).

67 Ibid..

68 Rich v. Braxton, 158 U.S. 375 (1895), accessed March 22, 2018, https://supreme.justia.com/cases/federal/us/158/375/case.html.

Attorneys John F. Keator, John A. Hutchinson, and S. Moors Waln for the appellants Benjamin Rich, et. al. Attorneys James H. Ferguson and W. Mollohan for the appellees Tamlin Braxton and his wife, the former Mary E. Caperton, et. al. Reports of Cases Argued and Decided in the Supreme Court of the United States, Book 39 (The Lawyers Co-Operative Publishing Co., 1901), 1022, accessed March 22, 2018, http://books.google.books. ${ }^{69}$ New Gauley Coal Company v. Hon. I.C. Herndon, Judge, etc., et. al., No. 5201, Supreme Court of Appeals of West Virginia, decided April 20, 1926, accessed March 22, 2018, https://westvirginia.lexroll.com/coal-corp-Vherndon-101-w-va-445-1926/. Camden is specifically mentioned in this matter, and it is useful to note that a member of the Byrne family represented the respondents in this matter.

${ }^{70}$ Camden v. Dewing et. al. Supreme Court of Appeals of West Virginia, December 9, 1899. The Southeastern Reports, Volume 34, accessed March 22, 2018, https://books.google.com. Camden prevailed in this action, represented by W.T. Ice and E.D. Talbott, with Mollohan \& McClintic, W.G. Matthews, and Frank Woods for the appellees.

${ }^{71}$ Cook, 31-32.
} 
into a material source of income was significant and Petty's formulations set the stage for a way to convert land use and productive labor to an industrial form that would be most beneficial to the state. $^{72}$ Petty's work on the political benefit of taxation of land and labor extended through to Alexander Hamilton's desire to calculate the potential taxable future of agrarian acres and farm production versus industrial endeavors, to determine a way to obtain the best return to capitalists who had invested in a growing empire. ${ }^{73}$ Stoll concurs, placing Hamilton's taxation policies as the first step in the transformation of United States society to a capitalist society:

Another way of saying this is that Alexander Hamilton and the monopolists performed Act One in the drama of extracting value from the mountains: taxation and speculation. A new generation of capitalists performed Act Two: full-scale industrialization. The timeline worked this way: Land purchases to gain hold of resources began as early as the 1840 s and intensified after 1865 . The state of West Virginia was founded in 1863. Its governors, legislators, and members of Congress all acted to attract industry. Railroad lines extended across the state between the 1850s and 1870s, the Baltimore and Ohio in the north and the Chesapeake and Ohio in the South. By 1880 , close to 56,500 stationary steam engines operated in the United States, all of them needing coal. ${ }^{74}$

With a national government that was wholly supportive of the use and appropriation of public and private lands through functions such as taxation, the active capitalist and industrialists would have been poor businessmen indeed if he did not recognize the limitless possibilities of West Virginia.

As Eli Cook notes, "in ensuring that the United States would remain a sound investment at all costs, he was creating a modern state whose financial foundation lay not in the hands of state legislatures but in the capital gains that fused the interests of the federal government with those of its wealthiest inhabitants."75 The opportunity to craft a state from scratch that met this model coalesced with the opportunities on the ground for men like Johnson Camden, who was able to take advantage of insider knowledge to align himself with the growing web of wealthy industrialists who were pushing west. Cook rightly places the race for "market productivity, capital accumulation, and profit maximization" on both the northern and the southern stages. ${ }^{76}$ The differences in ideology on the economic front can be seen, Cook deems, in the source of

\footnotetext{
72 Cook, 35-36.

73 Ibid., 62-64.

74 Stoll, 131.

75 Cook, 66.

76 Ibid., 164-165.
} 
market expansion, with the railroad holding the greatest sway in the north and cotton production in the south. The importance of the railroad to West Virginia is identifiable with the men who used the railroad's promise as a way to swing political votes during the creation of the new state. Rathbone Tract/Burning Springs

Partnership in the Rathbone oil land in Burning Spring (more than 500 thousand acres) was created as the Kanawha Burning Springs Company, and included Camden, John J. Jackson, Judge Gideon Camden, and William L. Jackson. Johnson's uncle, Gideon Camden was a political figure and massive landowner in his own right, with more than 29,000 acres taxed in his name in Braxton County, West Virginia in $1850 .{ }^{77}$ While his family was divided upon political issues, with some members of both the Camden and the Thompson families retaining loyalty to Virginia during the Civil War, "Camden, like many another inhabitant of the border states on the eve of the Civil War, was compelled to choose between his best interests on the one hand and loyalty to sentiments and traditions on the other."78 Camden's political life was rooted in the belief that the state of West Virginia must, by necessity, align with business interests in order to achieve economic advancement, but he also recognized the potential for personal wealth that exited in the state's vast natural resources.

While the history of extraction practices locates the majority of the practice in the $1890 \mathrm{~s}$ and later, at the time of the statehood movement, it was well-recognized that the potential for enormous wealth associated with oil, gas, lumber, and railroad industries existed in the western regions of Virginia. Waitman Willey, in his impassioned speech before the gathered assembly in Richmond upon the issue of secession, after espousing the number of reasons why secession was ill-advised, further cautioned that the western regions of the state were essentially cut off from the eastern portion of Virginia and that the state needed to hold together with the Union in order to protect those interests. ${ }^{79}$ Willey recognized that these interests, if properly managed and extracted, were "extensive enough to furnish the basis of an empire's greatness," and urged the assembly to avoid secession before "all these bright prospects are forever dashed to pieces." 80

\footnotetext{
771850 Braxton County, West Virginia Land Book.

78 Summers, 94.

79 Waitman Willey, speech to the Convention of Virginia, March 2, 1861, accessed January 31, 2018, http://www.wvculture.org/history/sesquicentennial/18610304.html.

80 Ibid.
} 
Johnson Camden became a larger tool in the war chest of empire when John D. Rockefeller used Camden to assist Standard Oil in its ability to gain favorable concessions from the B\&O. Rockefeller specifically enlisted Camden to use West Virginia refinery companies to break an alliance the $\mathrm{B} \& \mathrm{O}$ was using that was adversely affecting the $\mathrm{B} \& \mathrm{O}$ 's bottom line. ${ }^{81}$ In top secret meetings behind closed doors, Camden entered into an agreement that has never been fully exposed, although subsequent business dealings have created an outline of the protection Rockefeller created within the wilds of West Virginia. Under the shadow of title of Camden's business venture, Standard Oil operated unfettered and wholly monopolized "the consolidation of the oil industry of the territory contiguous to the Baltimore and Ohio Railroad east of Cincinnati and Columbus and south of Pittsburgh." 82

Camden's experience with the use of major turnpike roads for transport certainly left him well-versed in the opportunities that a rail system could provide for the transportation of resources across the state. Again, Camden's family influence here is not insignificant, as his uncle Judge Gideon Camden participated in a petition to the Virginia Assembly in 1855, wherein Harrison County citizens petitioned for removal of restrictions on rail travel that was interfering with their business interests. ${ }^{83}$ The citizens of Harrison County pushed back against the continued resistance of the Virginia legislature to deny further improvements upon the section of track called the NVRC but in truth simply a part of the larger $\mathrm{B} \& \mathrm{O}$ rail system), as the resistance was seriously impacting the economic future of their community. A significant portion of his substantial land holdings were in an area not serviced by a large rail system and somewhat removed from a large turnpike. As Dunaway notes, railroad service was lacking in the more interior areas of Appalachia, even after the railway expansion in the $1850 \mathrm{~s} .{ }^{84}$ For farmers and traders in livestock, the use of small roads may have sufficed, but Camden had moved on to trade within the global scale of the B\&O Railroad. The possibilities of wealth were clear to him, and he intended to move West Virginia forward into the type of trade that he envisioned, rather than back to trade along traditional agrarian models. Camden found a business and political partner in the most recognizable of West Virginia's industrialists, Henry Gassaway Davis.

\footnotetext{
${ }^{81}$ Summers, 172.

82 Ibid.

${ }^{83}$ Harrison County, Virginia, "Petition to the Virginia General Assembly," December 31, 1855. Legislative Petitions Digital Collection, Library of Virginia, Richmond, VA, accessed February 20, 2018, http://digitooll.lva.lib.va.us.

${ }^{84}$ Dunaway, 215.
} 


\section{$\underline{\text { HENRY GASSAWAY DAVIS }}$}

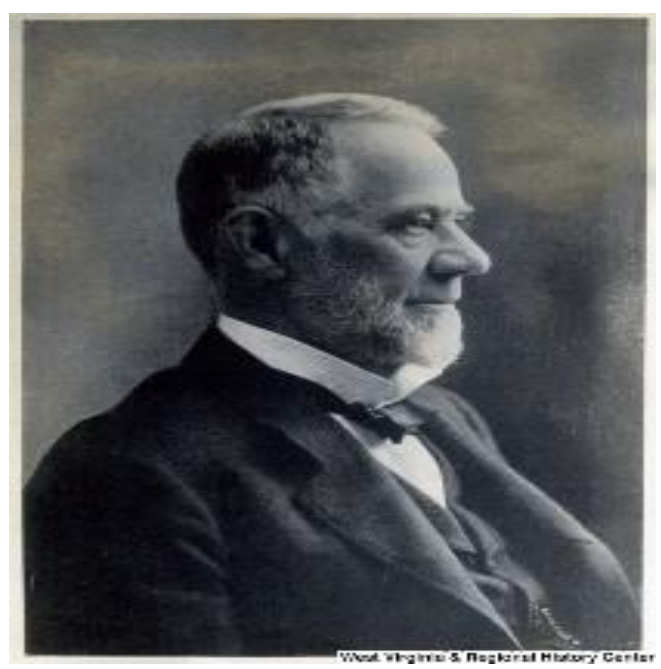

Figure 5: $\quad$ Henry Gassaway Davis

West Virginia History OnView, West Virginia and Regional History Collection West Virginia University Libraries

Davis' connection with big business should come as no surprise, as he grew up in the city of Baltimore, and was taken on an excursion as a child to see the laying of the cornerstone of the $\mathrm{B} \& \mathrm{O}$ station in $1828 .^{85}$ Before he was twenty years old, Davis was employed by the B\&O as a brakeman, later being promoted to conductor and line supervisor. ${ }^{86}$ Davis' obituary in the Elkins Inter-Mountain places Davis as an integral and valued employee of the $\mathrm{B} \& \mathrm{O}$ from the time of his youth. ${ }^{87}$ Davis and the business venture that he shared with his brothers relied upon supply connections they established with the Union, and it was clear that their commercial ventures had been established "mainly eastward and northward along the route of the B\&O." 88 The roots of Davis' future timber industry can clearly be seen in his continual purchase of timber lands that he utilized to supply the Union with timber to repair their damaged rail lines. ${ }^{89}$ Ronald Lewis points to Davis and his brothers purchasing in excess of 50,000 acres in the timber-rich Canaan Valley

\footnotetext{
${ }^{85}$ Thomas Richard Ross, Henry Gassaway Davis: An Old-Fashioned Biography (Parsons, WV: McClain Printing Company, 1994), 14.

${ }^{86}$ Ibid, 21-22.

${ }^{87}$ The Elkins Inter-Mountain, March 11, 1916. http://www.wvculture.org.

${ }^{88}$ Ross, 31.

89 Ibid..
} 
region of West Virginia post-war, through which Davis planned to establish a railway to extract the timber. ${ }^{90}$ Railroad construction through this rugged area would be greatly enhanced through Davis' political connections.

Davis' first foray into politics occurred with his election to the House of Delegates from Hampshire County in 1865, where he was instrumental in creating the new WV county of Grant, which was a piece of legislation that directly benefitted Davis' railroad interests. ${ }^{91}$ "So far as Davis was concerned, the motivation is to be found in his ultimate aim of building a railroad from Piedmont southwest through these counties and beyond to Greenbrier County. Mineral and Grant counties being smaller and with their own set of politicians would be more amenable to domination by railroad and other corporate interests than were the larger, predominately agricultural counties from which they were formed." 92 This initial legislative session not only saw Davis working to craft smaller counties, where he anticipated easier influence of politicians, but also saw the introduction of a chartered railroad project, ultimately titled the West Virginia Central and Pittsburgh Railroad Company (C\&P). ${ }^{93}$ Not surprisingly, Davis was one of the original incorporators of the company, which was not simply a rail line extension, but was specifically authorized by its charter to mine for coal, construct mills for lumber manufacturing, to transport coal or lumber, and to purchase land. ${ }^{94}$ One of the most significant features of the charter authorized by the WV Legislature was the ability of the C\&P to occupy land, value land, and purchase land through a de facto eminent domain policy that permitted the company to determine the amount it would pay for a tract of land and utilize the land as it saw fit. ${ }^{95}$ Ronald Lewis characterizes the state charter for the C\&P as "very liberal," as it gave the company the right to set out the line to best suit its purposes, no matter the inconvenience to the private landowner. ${ }^{96}$

Davis' ongoing connection to the B\&O was lengthy and deep, with Davis serving as pallbearer at the funeral of B\&O President John Garrett's funeral. ${ }^{97}$ Davis undertook a number of projects that spoke to internal improvements, but those improvements were often focused on creating avenues for his own personal business ventures. In his speech to constituents in Mineral

\footnotetext{
90 Lewis, 82-83.

91 Ross, 34-38.

92 Ibid., 38.

93 Ibid..

94 Ibid., 38-39.

95 Ibid., 38-40.

96 Lewis, Industrialist, 20.

97 Ross, 158-159.
} 
County, West Virginia, Davis highlighted the promise of federal funding to improve the James River Company, and to expand railway transportation by way of a wholly federally funded project. $^{98}$ Davis intimated that, by permitting the federal government to take over property at Harpers' Ferry, the federal government would bring additional employment to the area, an idea that runs directly counter to the image of the self-reliant West Virginian. ${ }^{99}$ Like his political and business contemporaries, Davis believed that the answer to West Virginia's future lay in her ability to market herself by "generous invitation and hearty welcome" to those who could extract her natural resources. ${ }^{100}$ The ability to extract natural resources was of particular interest to Davis, who engaged in land deals with Johnson Camden to secure a piece of the valuable "Caperton" tract. ${ }^{101}$ By advocating for federal intervention to secure the economic success of West Virginia, and through his land dealings that secured a place for his own personal economic success, Davis moved rapidly from a "hard working boy" who had "made every dollar of his money" into the sphere of the political elite. ${ }^{102}$ It is important to note that, while the Tucker County, West Virginia area that was central to Davis' timber production ranked him as "hard working," the more removed Grafton newspaper saw Davis as more like Vanderbilt, who was known to "use his fortune as a lever to move even greater masses of wealth and personally affect the economy nationwide." 103

When Davis himself entered both the railroad industry and the timbering business, his devotion to the bottom line was directly related to the loss of at least one small community. Once the county seat of Tucker County, St. George, West Virginia became a mere footnote in the history of the state after Davis made the decision to construct the line of the West Virginia Central and Pittsburg Railway in "the most direct and most profitable route south" from Maryland, a decision that took the line to land owned by a family named Parsons who agreed to "start a new town with the intention that it have a railroad, and thus become the county seat."104 With some financial backing coming in the form of an inheritance to his wife, Davis opened a store and began investing

\footnotetext{
98 Henry Gassaway Davis, Speech in Mineral County Convention on Saturday, August 15, 1874, 24, https://babel.hathitrust.org/cgi/pt?id=loc.ark:/13960/t6k076z88;view=1 up;seq=30.

99 Ibid..

100 Ibid..

101 Webster County Deed Book 16, Page 410.

102 Grafton Eagle, reprinting a story from the Tucker County Pioneer entitled "West Virginia's Vanderbilt," March 27, 1884. Microfilm Collection, WVU WVRHC, Morgantown, WV.

103 T.J. Stiles, The First Tycoon: The Epic Life of Cornelius Vanderbilt (New York: Alfred A. Knopf, 2009$), 365$. 104 Joseph Super, "West Virginia Incorporated: Religion and the Railroad in the Timber Counties," West Virginia History: A Journal of Regional Studies, New Series, Volume 7, Number 2, Fall 2013, accessed March 22, 2018, https://muse-jhu-edu.www.libproxy.wvu.edu/article/523934.
} 
in the purchase of "timber and coal lands which he had carefully examined during the years he had traveled as brakeman and conductor through the largely undeveloped area of northern Virginia (later West Virginia)."105 Davis's biographer makes clear that Lincoln had the distinct desire to maintain connection with the B\&O for purposes of securing the Union's access to that critical railway. "President Lincoln and his advisors realized from the beginning that if Maryland seceded, Washington, DC, would be surrounded by enemy territory and a vital transportation facility connecting Washington to the North and West, the B\&O, would be lost. Lincoln, likewise, wanted northwestern Virginia in the Union in order that the B\&O line to Wheeling and the Ohio River should be kept under national control."106 The response of the people of West Virginia to Davis' success was mixed, with his undoubted political success culminating in a nomination for VicePresident in 1904, the Grafton Eagle identified Davis as a "tariff protectionist, a millionaire, and monopolist." 107

During the 1872 Constitutional Convention, in which many reforms to the state's original constitution were enacted, it is apparent that the influence of industry had been significant upon the original legislative structure of the state. "Granville Hall, however, feared that a convention, under the influence of special interests, might pose a danger even more serious than enabling the state to create debt to aid internal improvement schemes." 108 Granville Hall, in particular, was concerned about the methods by which "great and large economic interests always seek to escape some part of their tax burden. The interests, particularly the railroads, already bent the state legislature to their purposes. The Baltimore and Ohio Railroad refused to pay any taxes until 1869 and then paid taxes afterward at a very low rate and under protest." 109 The legislative session previous to the 1872 Convention had seen "the Baltimore and Ohio secured the election of its confidential agent, Henry Gassaway Davis, as the first Democratic U.S. senator."110 But, as Dunaway points out, it was the process of accumulation of huge tracts of land prior to the Civil War that led to the ability of national capitalists to reap the enormous benefits of their speculation: "Throughout the region, governmental insiders - like David Goff, Gideon Camden, Henry Gassaway Davis, Arthur I. Boreman, George Cookman Sturgiss, and Stephen B. Elkins of West

\footnotetext{
105 Ross, 25.

106 Ibid., 29.

107 Grafton Eagle, March 27, 1884. Microfilm Collection, WVU WVRHC, Morgantown, WV.

108 Stealey, Convention, 294.

109 Ibid..

110 Ibid..
} 
Virginia - exploited their state and congressional positions to acquire Appalachian holdings that they could resell or syndicate with distant speculators." 111 Exploitation of the state's resources has been thoroughly documented in the thirty-year period following the Civil War, but the foundation of land accumulation by industrialists and capitalists began well before the antebellum period. Judge Gideon Camden, uncle of Johnson Camden, received considerable correspondence from speculators from New York and other areas, including W.H. Tyler, who advised Camden in 1861 that he looked forward to a time when political issues of secession would die down in order to foster "such an impulse to business \& to values in your Country as has never been seen out of the United States." 112

The vast influence of railroad interests was apparent in discussions during the 1872 reform convention, where it was anticipated that by 1882 , the combined property ownership of the $\mathrm{B} \& \mathrm{O}$ and the $\mathrm{C} \& \mathrm{O}$ would constitute "one-fourth of the state's taxable property."113 This type of situation creates a two-fold problem for such a young state: by holding such a large stake in the state, such interests are easily able to influence voting upon critical legislative issues such as corporate taxation and, by simple virtue of their ownership interests, they limit the right of the state to tax potential private property ownership that might otherwise utilize that land. John Joseph Wallis points to the strong influence that the corporate form had upon the evolution of state constitutions, noting that "[t]hese pressures were particularly strong wherever large amounts of undeveloped land stood to appreciate in value from better transportation and financial infrastructure." 114 The involvement with states in granting charters to corporations while protecting citizens from undue tax burdens was implicit throughout the United States, and the Virginia legislature was not immune to this problem, frequently citing tax burden as a reason to limit expansion of internal improvements in the western regions of the state (need a citation here). "Public debts and corporations were different facets of the same problem: how to prevent a democratic republic from being captured by the interests of a narrow political elite." 115 The

\footnotetext{
111 Dunaway, 253.

112 W.H. Tyler to Judge Gideon Camden, May 30, 1861, letter, Gideon D. Camden (1805-1891) Papers, A\&M 1188 (Morgantown, WV: WVU WVRHC).

113 Stealey, Convention, 302.

114 John Joseph Wallis, “Constitutions, Corporations, and Corruption: American States and Constitutional Change, 1842 to 1852," The Journal of Economic History, Vol. 65, No. 1 (Mar., 2005), 212, accessed September 17, 2017, http://www.jstor.org/stable/3875048.

115 Ibid., 240.
} 
conflict between adequate development, responsible tax burden, and personal economic and political advancement is seen in the creation of West Virginia, where "the very nature of the democratic process made certain ways of doing things, taxless finance in particular, appear very attractive ex ante to policy makers."116

Samuel Woods, a former Barbour County Confederate who favored Virginia's secession, believed strongly that the undue influence of the B\&O was actually adverse to the long-term interests of West Virginia, as it and other large railroad interests "instead of advancing the state's interest by encouraging population growth, diverted immigration to the west."117 Debate over the role that railroads and similar industrial enterprises did and should play in West Virginia extended throughout many of the legislative sessions, with central arguments against encouraging railroad development including: Nicholas Fitzhugh of the Kanawha Valley, who proposed that "railroad corporations substantially influenced the state and national legislature, all courts, and most executives." 118

The final man to consider in the complex web of politicians and industrialist is the forgotten mountaineer. Christopher Phillips paints the collective picture of the influx of population in the Midwest and the Ohio River Valleys as a "pluralistic society," made up of transplants from both the north and the south, with widely differing political and social attitudes. ${ }^{119}$ The mechanism by which the ideology of the north utilized the political system to create a state through which maximum return for investment could be attained transformed the collective transplants in West Virginia, leaving the area voiceless in a large sense. The process by which Henry Clay's American System sought to mold the Midwest and the pushback that system found from the average citizen found a battleground in West Virginia, where the powerful industrial voices were able to quash any conflicting ideas. Similarly, the vote upon statehood creation rested nearly exclusively in the most industrial portion of the area that was voting upon the issue. Stoll identifies the creation of West Virginia as: "more of a conspiracy than a mass movement. The panhandle voted in favor of the issue by 70 percent. But the middle tier voted it down by 70 percent. And the southernmost

\footnotetext{
116 Wallis, 248.

117 Stealey, Convention, 427.

118 Ibid., 501.

119 Phillips, 21.
} 
tier, consisting of one-third of the new state, including the counties with the richest coal deposits, didn't vote for it at all." 120

There is, in fact, very little evidence to suggest that the creation of the separate state of West Virginia was truly the intention of the average citizen of that area, but can more accurately be described as created by and for a group of men whose individual interests were served by the action. Rest assured, there were members of the statehood brotherhood who had no material or monetary interest in the creation of the new state (men like Gordon Battelle and other abolitionists and individualists who placed great stock in the republican virtues they so loved), but there were a great many men who saw and grasped at the immense opportunities that lay west of the Allegheny mountains. Phillips points out that “[ $\mathrm{t}] \mathrm{he}$ more remote the residents' access to transportation networks, the more likely it was that Democratic candidates would best their Whig contenders."121 The push by active West Virginia politicians to advance the cause of the railroad industry was a part of the process by which "frenzied modernizers attempted to recast western independence as achievable by, and not despite, government interference." ${ }^{122}$ It is, however, the push of the modernizers that quieted the voices of the citizens whose needs they so loudly proclaimed as their own. As Steve Stoll identifies in this analysis of the longstanding failure to thrive of Appalachia, "[a]s long as political elites pretended not to see the flaunting of private property and constitutional authority, they could continue to believe that the interests of the backwoods aligned with those of the nation-state."123 The alignment of society to an ideology of progress that was dependent upon "constant expansion into new environments" required that the members of each throughway conform their identities with that governing ideology: "Tens of millions of people link their identities, the trajectory and meaning of their lives, to a social system with all sorts of destructive tendencies, associating it with the highest aims of society itself." 124 Super identifies industrialization as central to the "significant political, social, and economic shifts" that occurred in West Virginia counties that became dependent upon the extractive industries, the railroad, and the capitalists who brought these identities together. ${ }^{125}$ In some instances, small communities saw guerilla warfare and other instances of violent revolt break out

\footnotetext{
120 Stoll, 134.

121 Phillips, 59.

122 Ibid., 60.

123 Stoll, 11.

124 Ibid., 29.

125 Super, 36.
} 
in opposition to industrial encroachment. Ronald Lewis' study on the violence in the Canaan Valley timber area and Altina Waller's examination of the violence of the Hatfield and McCoy feud both exemplify push-back against industrial forces. ${ }^{126}$ For other communities, however, the impact of industrialization was far less dramatic, as the identity of the area subtly shifted and aligned to meet the expectation of the industry. It was, as Super notes, the promise that this ideology of "economic prosperity and earthly gain" brought to the rural counties of West Virginia that contributed to the social and political shifts. ${ }^{127}$ One of the most identifiable ways to examine this transformation of an environment to conform to the ideology of an industry is to regard the example of Barbour and Taylor Counties in West Virginia, where the specific influence of the B\&O Railroad is observed

126 Lewis, The Industrialist and the Mountaineer. Waller, Feud.

127 Super, 37. 


\section{CHAPTER FOUR: Influence Changes Communities}

The pivotal role played by the Baltimore and Ohio Railroad $(\mathrm{B} \& \mathrm{O})$ in the shaping of the state of West Virginia is critical to the examination of the intersection between business, community, and government, as the weight of the $\mathrm{B} \& \mathrm{O}$ on the fulcrum of sectionalism in West Virginia was a powerful influence on the political views of communities and state-makers. This influence of a growing American ideology of empire based on industrial expansion was waged by the $\mathrm{B} \& \mathrm{O}$ at the local, state, and national levels and was a powerful current running beneath the multitude of reasons that West Virginians vowed to remain in the Union and separate from Virginia. The history of West Virginia's separation from Virginia has been examined by historians over the years, as the process that cleaved the state in two is unmatched in the history of the United States. West Virginia historians have laid important groundwork on the broad sectional issues of political and social alliances, and have addressed the fact that West Virginians were less vested in the slave economy that characterized the Confederacy and were less frequently tied to family histories that shaped the Old Dominion. ${ }^{1}$ While economic issues have been broadly considered in each of these valuable studies, this chapter seeks to highlight the specific impact that the $\mathrm{B} \& \mathrm{O}$ exerted on the formation of West Virginia to highlight the way that industry, state-making, and empire building coalesced in the Civil War period.

By examining the influence of the B\&O in Barbour and Taylor Counties, both of which demonstrated a pre-Civil War Confederate presence, it is possible to understand that West Virginia sectionalism was not simply an issue of politics, but was influenced by regional economic opportunities and expanding industries. As these two rural counties demonstrate, West Virginia's path to statehood was never simply a demand for expanded voting rights or a desire to separate from a slaveholding planter elite, but was shaped by the railroad industry. This chapter seeks to broaden the history of West Virginia sectionalism through an analysis of how the B\&O influenced support for the Union in counties where the B\&O became a prominent force. ${ }^{2}$ The use of local

\footnotetext{
1 Well-developed histories of West Virginia sectionalism include Charles Ambler's Sectionalism in Virginia from 1776-1861 (New York: Russell \& Russell, Inc., 1964) and Richard Orr Curry's A House Divided: A Study of Statehood Politics and the Copperhead Movement in West Virginia (Pittsburgh, PA: University of Pittsburgh Press, 1964). John Shaffer's Clash of Loyalties honed his focus sharply on Barbour County, West Virginia to analyze patterns of loyalty at the local level, which contributes to the historiography of WV sectionalism.

2 While the state of Maryland and Baltimore, specifically, had noted Confederate interests, John W. Garrett, president of the B\&O since 1858, "knew that both the prosperity and the future of his railroad lay with the North, the West, and
} 
histories and census data to compare two geographically linked counties are valuable in the analysis of ways that the B\&O Railroad influenced both statehood and sectionalism throughout the Civil War era. West Virginia's path to statehood, much like the nation's path to Union, was never a one-way track, but more a nebulous web of economic, social, and political factors that shifted to meet the needs of a people. Allegiance to state and allegiance to nation are broad histories complicated by economic forces, and the experiences of Barbour and Taylor counties are pertinent to the examination of the ways that allegiance is formed and nations expand.

The interior counties of Barbour and Taylor are the focus of this narrative, and employment patterns in the 1850 and 1860 censuses will be integral to the analysis of shifting ideologies. ${ }^{3}$ Because neither county touches a bordering state, the particularly strong influence of pro-secession ideology of Virginia or pro-Union ideology of Ohio are removed from the immediate geography of this study. Both counties showed an increase in the numbers of working men and a decrease in slave ownership from 1850 to 1860 . Both counties were also largely dependent upon farming and farm labor as the dominant industry in $1850 .{ }^{4}$ The influence of the B\&O caused demographic shifts with the increase of railroad jobs and employment ancillary to the railroad in Taylor County during this period. A comparison of the 1850 census data for Barbour and Taylor Counties confirms that there were similarly high numbers of men employed in farming or farm labor, with Barbour County showing $88.55 \%$ of its adult male population in this field, and Taylor County showing $85.03 \%$, the changes point to dramatic differences between the counties. When the lens

the Union, rather than the South." John F. Stover, History of the Baltimore and Ohio Railroad (West Lafayette, IN: Purdue University Press, 1987), 94-101. While the shifting allegiance of the B\&O is not the subject of this paper, it is worth noting that allegiance can be transitory and shifting at the local, the state, or the national level.

${ }^{3}$ Methodology here begins with the standard used by the North Carolina Digital History project to analyze occupations reported in antebellum censuses, although some jobs are combined by industry specifics for purposes of this study. David Walbert, "Occupations in 1860," Learn NC, accessed September 22, 2017,

http://www.learnnc.org/lp/editions/nchist-antebellum/5350.

For this project, all men reporting an occupation were counted, no matter their age, and men between the ages of 1865 with no occupation listed were counted as such. The category of "day laborer" is separated in the 1860 Taylor County calculations because, in that census, these workers did not conform to prior census patterns of laborers living in the same household with a farmer.

${ }^{4}$ All census data used throughout from the following sources:

1850 U.S. Census, Barbour County, VA, digital image. AncestryLibrary.com, accessed October 10, 2017. https://www.ancestrylibrary.com.

1850 U.S. Census, Taylor County, VA, digital image. AncestryLibrary.com, accessed October 10, 2017.

https://www.ancestrylibrary.com.

1860 U.S. Census, Barbour County, VA, digital image. AncestryLibrary.com, accessed October 10, 2017.

https://www.ancestrylibrary.com.

1860 U.S. Census, Taylor County, VA, digital image. AncestryLibrary.com, accessed October 10, 2017.

https://www.ancestrylibrary.com. 
is focused upon the non-farming occupations performed by men in each county, the differences between the counties are striking.

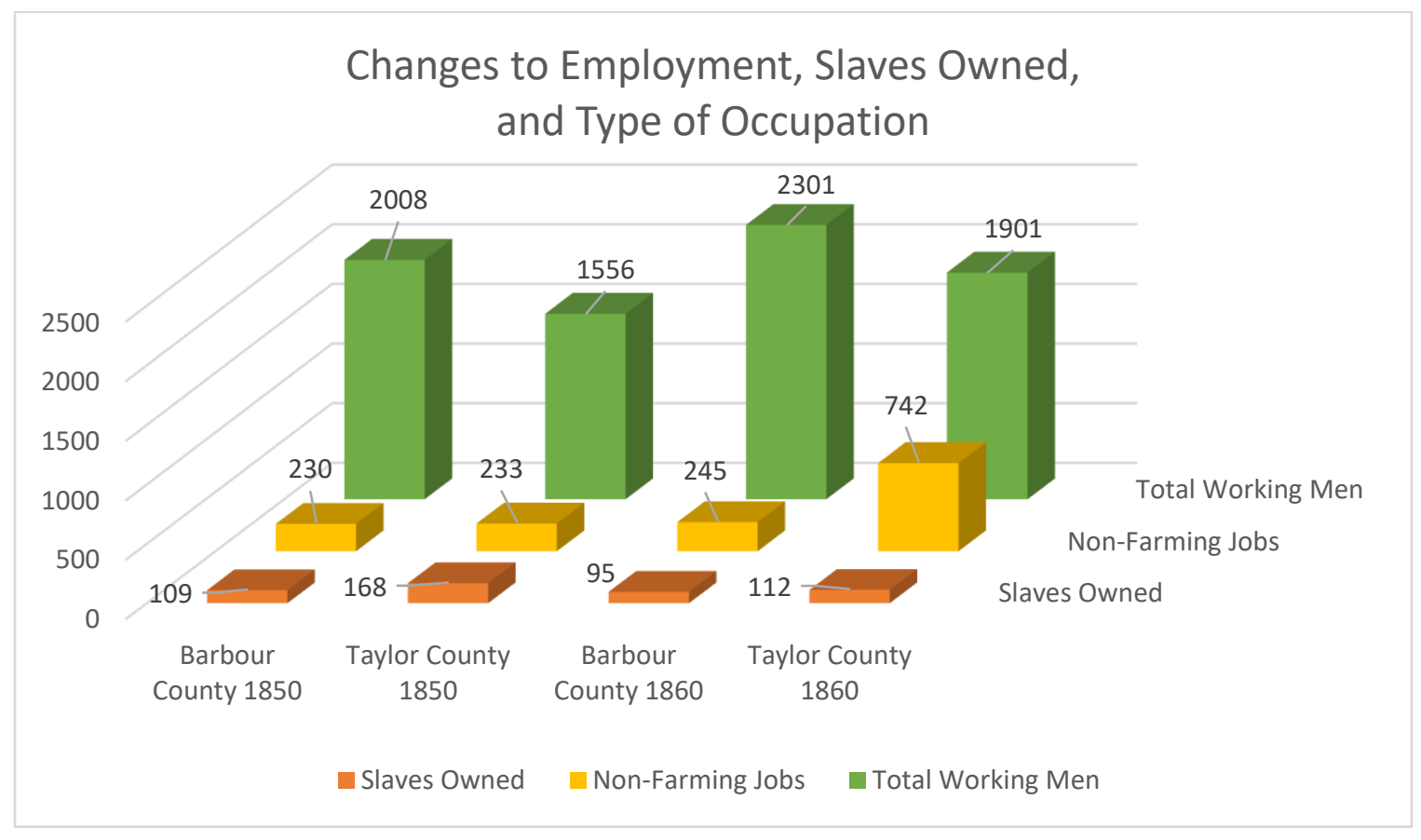

\section{Figure 6: $\quad$ Changes to Employment, Slaves Owned, and Types of Occupations} Comparison between Barbour and Taylor Counties, West Virginia - 1850-1860

Barbour and Taylor Counties were geographically linked in reality and in the minds of the professional engineers of the B\&O Railroad, who were actively working to identify the most costeffective way to move west to the Ohio River across mountainous terrain. An 1843 engineering map of proposed routes to Ohio illustrates that the $\mathrm{B} \& \mathrm{O}$ was investigating multiple routes through the northern area of West Virginia, and both Barbour and Taylor Counties remained viable considerations for the ultimate route to the "extension of the Baltimore \& Ohio Rail Road to the western terminus." 5 While Barbour and Taylor counties were linked to each other geographically, when the B\&O established a transportation hub in Taylor County in 1851 as the railroad made its way west toward Wheeling and beyond, the trajectory of these rural communities began to diverge. ${ }^{6}$ With a formative history so connected to the B\&O, the story of these two West Virginia

\footnotetext{
${ }^{5}$ Baltimore And Ohio Railroad Company. [Map of the county west of Cumberland towards the Ohio river, showing the various lines surveyed or reconnoitred (sic) for the extension of the Baltimore \& Ohio Rail Road to its western terminus referred to in the report of the chief engineer of September 20th, 1843]. [N.P, 1843] Map. Library of Congress, accessed October 29, 2017, https://www.loc.gov/item/98688590/.

${ }^{6}$ John Stover notes that the town of Grafton was created from a smaller, rural community at the point where the Baltimore and Ohio met the Northwest Virginia Railroad. John F. Stover, History of the Baltimore and Ohio Railroad (West Lafayette, IN: Purdue University Press, 1987), 82, 87.
} 
counties in the broader national narrative remains critical to an understanding of the force of industry in shaping communities, states, and nations. Barbour and Taylor counties were part of a larger geographic area that had long sought an answer to their transportation crisis, and part of a nation transforming both its trade routes and its tolerance for industry influence on issues of governance.

Early transportation complications were at the root of West Virginia's demands for a voice within the Virginia legislature, with much of the state west of the Alleghenies taking the position that eastern planter voices were limiting capacity for travel and trade. In response to ongoing demands for action, the Cumberland Road was built in 1818, easing tensions for a period. While the explosive growth of trade in western markets shaped transportation and merchant activity during the early nineteenth century, the nation continued to rely largely on a north-south trading alley that utilized canals and waterways for movement of goods. ${ }^{7}$ A trip to observe British railroad innovations convinced Baltimore capitalists in 1827 to begin investment into developing an eastwest trade route that was railroad dependent. ${ }^{8}$ Initially, a route for the B\&O through the southern portion of West Virginia was heavily investigated, but the Virginia legislature placed multiple restrictions and tax consequences upon proposed routes, despite efforts by West Virginians who attempted to negotiate a favorable resolution. ${ }^{9}$ The importance of internal improvements was a sticking point for West Virginians, but the presence of the $\mathrm{B} \& \mathrm{O}$ was simply not welcomed by the Virginia political power structure. As early as 1828, Virginia Governor John Floyd was cautioned by Judge Lewis Summers that, while internal improvement might provide opportunity to "invigorate its agriculture," the presence of the B\&O would constitute a "spirit of interference in our own State."10

While the Virginia power structure pushed back against the $\mathrm{B} \& \mathrm{O}$, West Virginia cities such as Parkersburg vied for the opportunity to join with the railroad company as an answer to their deficient internal improvements. A committee in Parkersburg felt so strongly about the economic initiative they could gain by obtaining the line destination of the $\mathrm{B} \& \mathrm{O}$, they wrote

\footnotetext{
7 Stover, 1-14.

${ }^{8}$ Ibid., 15-17.

${ }^{9}$ James D. Dilts, The Great Road: The Building of the Baltimore and Ohio, the Nation's First Railroad, 1828-1853

(Stanford, CA: Stanford University Press, 1993), 56.

${ }^{10}$ Judge Lewis Summers to Virginia Governor John Floyd, January 4, 1828 letter, Ms80-131 thru Ms80-187)

(Charleston, WV: State Archives, Charleston, WV).
} 
directly to B\&O President John W. Garrett on November 12, 1836, outlining their case. ${ }^{11}$ Long before he took a prominent seat at the WV Constitutional Convention, future Wood County delegate, Peter Van Winkle, advised officials of the city of Parkersburg that internal improvements were essential to protecting their economic and industrial interests. ${ }^{12}$ While espousing his neutrality on an issue of proposed railroad bonds in Parkersburg, Van Winkle similarly advised that: "I would not have performed the amount of labor I have, but for the interest I sincerely feel in the welfare and character of the town."13 Van Winkle was hardly an impartial bystander, as he had close ties to the Northwestern Virginia Railroad, which later became part of the $\mathrm{B} \& \mathrm{O}$, and he continued to advocate for the necessity of the B\&O's path through West Virginia throughout his political career. ${ }^{14}$

Through the 1840s, the B\&O failed to contract favorable terms with the Virginia legislature to lay line across the state to the Ohio River. The B\&O was committed to extending their line west in the most expedient manner, and when the Virginia legislature continued to refuse to permit the line to extend through the southwestern part of the state, the B\&O simply readjusted the geographic placement of its rails. On February 19, 1845, the Virginia Legislature passed a resolution to authorize the $\mathrm{B} \& \mathrm{O}$ to "construct their road, in whole or in part, through the territory of this state, so as to terminate and strike the Ohio river at the City of Wheeling in the county of Ohio."15 After several years of negotiations, acceptable terms were reached in the legislative term of 1846-47, and the $\mathrm{B} \& \mathrm{O}$ began expansion through West Virginia, though the limitations placed upon the $\mathrm{B} \& \mathrm{O}$ would continue to cause sectional complaints as Virginia banned branch lines south of Wheeling. ${ }^{16}$

Virginia was not wholly opposed to internal transportation improvements, and major roads such as the Staunton-Parkersburg Turnpike, were developed and opened into West Virginia during

\footnotetext{
${ }^{11}$ Peter Van Winkle to John W. Garrett, November 12, 1835, letter, Peter Godwin Van Winkle (1808-1872) Papers, A\&M 136, Box 1 (Morgantown, WV: WVU WVRHC).

12 Peter G. Van Winkle to Charles P. Bailey, Esq., April 12, 1842, letter, Peter Godwin Van Winkle (1808-1872) Letter, A\&M 18 (Morgantown, WV: WVU WVRHC).

${ }^{13}$ Peter G. Van Winkle to the Committee of Council, October 12, 1855, letter, Peter Godwin Van Winkle (18081872) Letter and Receipt for Stock, A\&M 142 (Morgantown, WV: WVRHC).

14 Jacob C. Baas, Jr., “John Jay Jackson, Jr.: Business, Legal and Political Activities, 1847-1859," West Virginia History, Vol. 50 (1991), 63-78.

15 "An ACT to authorize the Baltimore and Ohio railroad company to complete their road through Virginia to the Ohio river, and for other purposes." Acts of the General Assembly of Virginia: Passed at the Session Commencing December 2, 1844, and ending February 22, 1845, in the Sixty-Ninth Year of the Commonwealth (Richmond, VA: Samuel Shepherd-Printer to Commonwealth-1845), 69. Accessed October 15, 2017 https://babel.hathitrust.org/cgi/pt?id=njp.32101073363267; view=1 up;seq=77.

${ }^{16}$ Stover, 67.
} 
the period of 1847-1856, which caused expansion of settlement that brought people further west and created new market opportunities. ${ }^{17}$ The opening up of trade routes influenced the immediate economic interests of the individuals living in the area and increased the opportunities for investors of other industries, a notion that was not lost on venture capitalists across the nation. As the population of the west expanded, merchants and suppliers sought ways to obtain goods at the cheapest price for transport to western markets in order to meet the demands of a nation whose collective identity shifted with each mile it moved west. Profit, rather than regional allegiance, shaped economy and major trade centers such as New York City saw a great increase in traffic from west of the Appalachians by the 1850s. ${ }^{18}$ The need for viable transportation in the transforming market economy became a growing national concern, not simply an internal state issue.

West Virginians were disenchanted with the capacity for the Virginia legislature to meet demands for internal improvement, and the economic opportunities of the railroad industry forged a sectional bond that drove West Virginians to actively pursue a way to separate themselves from the entity blocking economic advancement and promotion. ${ }^{19}$ At the same time the cities of Parkersburg and Wheeling began to vocally identify the B\&O as an opportunity to enhance the economic futures of their cities, they also began to recognize that the railroad industry could unify a nation: "[f]or near a quarter of a century the project of connecting the city of Baltimore with the Ohio River at Wheeling, has been claiming the attention of our citizens and the public, and now we are called upon to celebrate in a few days the accomplishment of the great event, so important in its bearing upon the great Commercial interests of the entire Union." ${ }^{20}$ Profit tied to effective transportation of goods caused allegiances to shift beyond political to economic needs, with railroads recognized as a unifying agent for national progress. Newspapers outside of Wheeling and Parkersburg advised that the railroad's value, no matter where it was ultimately situated, would be vital to all areas, even those who were not graced with actual rail lines or terminus locations. ${ }^{21}$

\footnotetext{
17 Shaffer, 24.

18 Sven Beckert, The Monied Metropolis: New York City and the Consolidation of the American Bourgeoisie, 18501896 (Cambridge, NY: Cambridge University Press, 2001), 23.

${ }^{19}$ Sean Patrick Adams, Old Dominion, Industrial Commonwealth: Coal, Politics, and Economy in Antebellum America (Baltimore, MD: The Johns Hopkins University Press, 2004), 211.

20 “The Approaching Celebration,” Wheeling Intelligencer, January 4, 1853, accessed September 8, 2017, http://www.wvculture.org/history/transportation/bando02.html.

21 "Railroad to the Pacific," The Monongalia Mirror, Morgantown, VA September 1, 1849. Microfilm Collection, WVU WVRHC, Morgantown, WV.
} 
The B\&O no longer considered itself simply a business venture, it considered itself a tool of national unity. Historian George Bancroft, who delivered a speech at the reception in 1857 to commemorate the B\&O's achievement of reaching Ohio, noted that the railroad was now helping America achieve the destiny that was set out by the founding fathers. ${ }^{22}$ For many West Virginians, the success of the $\mathrm{B} \& \mathrm{O}$ was now equated with the success of the Union, and, because some believed that Virginia would never cease its "oppressive measures" toward the B\&O, the interests of the Old Dominion became disparate from those of West Virginia. ${ }^{23}$

By 1861, the northwestern counties that had seen the benefit of the B\&O believed that the legislature continued to place roadblocks that prevented West Virginia from effectively moving their products and developing a way to extract the natural resources of their region. ${ }^{24}$ As the nation moved west, the industry that helped it move west changed not only the market that was available for trade, but it also shifted the geographic path of markets " $\mathrm{t}]$ rade that had previously traveled north and south along coasts and rivers now went east and west on railroads." 25 West Virginia was clearly placed on the geographic line to facilitate the westward movement of the B\&O and, with the B\&O's entrance into West Virginia, that area of the state became more aligned with a political ideology of western exceptionalism rooted in economic growth they saw manifested by the railroad. ${ }^{26}$

Because the Virginia legislature was concerned about increased competition with Maryland should the B\&O come through the southwestern part of the state, they continued to deny a charter along that path to the $\mathrm{B} \& \mathrm{O}$, despite support for the route by residents. ${ }^{27}$ During the 1861 meeting of the convention on West Virginia statehood held in Wheeling, Virginia, delegate Van

\footnotetext{
${ }^{22}$ William Prescott Smith, The Book of the Great Railway Celebrations of 1857: Embracing a Full Account of the Opening of the Ohio \& Mississippi, and the Marietta \& Cincinnati Railroads, and the Northwestern Branch of the Baltimore and Ohio Railroad with Histories and Descriptions of the Same; and an Account of the Subsequent Excursion to Baltimore, Washington and Norfolk, and the Receptions and Entertainments there of the State Authorities of Ohio, and the Municipal Representatives of St. Louis, Cincinnati and Chillicothe (New York: D. Appleton \& Co., 1858), 216.

${ }^{23}$ George R. Latham to William Smith, Master of Transportation for the B\&O, August 9, 1865, letter, 1861-1863 West Virginia, 16.1.4, 28, MS2003, 383 (Baltimore, MD: Hays T. Watkins Research Library of the B\&O Railroad Museum Archives (HWRL).

${ }^{24}$ Curry, 23.

${ }^{25}$ Heather Cox Richardson, West from Appomattox: The Reconstruction of America after the Civil War (New Haven, CT: Yale University Press, 2007), 79.

${ }^{26}$ William A. Link, "'This Bastard New Virginia': Slavery, West Virginia Exceptionalism, and the Secession Crisis," West Virginia History: A Journal of Regional Studies, New Series, Volume 3, Number 1 (Spring 2009), 53.

${ }^{27}$ Ambler, Sectionalism, 125.
} 
Winkle noted that he had spent most of his time in the Virginia statehouse trying to "fight off in the best way I could the attempts that were made in every session of the legislature, without an exception, to place restrictions on the Baltimore and Ohio Railroad." 28 Van Winkle was not alone in his concern, as residents in the northwestern interior counties of Virginia heavily supported the B\&O's plan and began to embrace the idea of separation if denied the privilege of aligning themselves with the powerful industrial force of the B\&O. Ultimately, the Northwestern Virginia Railroad was founded independently to create a line from Grafton (Taylor County) to Parkersburg and was swiftly made part of the larger B\&O holdings. ${ }^{29}$ The decision to move the railroad line north, and the construction of the road from Taylor County had a profound effect on sectionalism in that county.

Taylor County's importance to westward expansion was realized when the B\&O settled its route through Parkersburg to Wheeling, establishing a station at Three Forks Creek. The presence of the B\&O in Taylor County, particularly in the town of Grafton that grew up around the B\&O, confirms that even interior counties of West Virginia should not be categorized as isolated rural counties, because they were part of a connected system of communities linked together in an ideology of industry and empire that was rapidly sweeping west. Judge Lewis Summers, writing to Virginia Governor Floyd cautioned that the Southern states must maintain control of their own transportation needs because expanding large cities of commerce would become the "cords of empire" from which those transportation alleys extended. ${ }^{30}$ Virginia anticipated extending a westward line from Norfolk and Richmond, and hoped to hold control of their own transportation alleys by limiting the B\&O's connections to and through Virginia. ${ }^{31}$ Connection to the markets and the economies of the states to which the B\&O traveled placed West Virginia in the orbit of Free states, a connection that Elizabeth Fox-Genovese and Eugene Genovese find significant to sectionalism based on economic factors. ${ }^{32}$ The importance of the B\&O was felt throughout West Virginia as the area moved toward formal separation from Virginia, as witnessed by a group of citizens from Piedmont (Mineral County, WV) who wrote directly to B\&O President Garrett to

\footnotetext{
28 Ambler, Debates and Proceedings, 451.

29 Ambler, Sectionalism, 242-243.

30 Judge Lewis Summers, to Governor John Floyd, August 18, 1830, letter, Judge Lewis Summers Collection, Ms80131 to Ms80-137) (Charleston, WV: WV Archives).

31 Stover, 67.

${ }^{32}$ Elizabeth Fox-Genovese and Eugene D. Genovese, Fruits of Merchant Capital: Slavery and Bourgeois Property in the Rise and Expansion of Capitalism (New York: Oxford University Press, 1983), 256.
} 
advise him that delegates would be gathering to form a new state because they realized that "they are mainly dependent on the B\&O for their subsistence." 33

With an industry that offered interior counties of West Virginia an avenue to compete with counties with access to waterway trade, and with the Virginia legislature continuing to block access to trade and transportation, the reasons to embrace the benefits of the $\mathrm{B} \& \mathrm{O}$ were obvious. ${ }^{34}$ At the time Taylor County aligned its interests with the B\&O, it was not significantly different than neighboring Barbour County. Like many other counties in West Virginia, both counties suffered from divided political loyalties. The pattern of pre-Civil War allegiance throughout West Virginia varied widely and, as West Virginia scholars have noted, there was simply not a singular West Virginian allegiance to the Union. ${ }^{35}$ Historian Richard Curry, whose analysis of political tension in West Virginia is foundational, notes that the strongest Union sentiment in West Virginia was seen in "those counties along the Ohio River and the Pennsylvania border, and along the line of the Baltimore and Ohio Railroad." 36 Taylor County's Union allegiance falls squarely within Curry's analysis, while Barbour County, removed from the direct influence of the B\&O, had a more vocal and active Confederate presence. One way to examine dependence on the $\mathrm{B} \& \mathrm{O}$ is to examine employment patterns at the local level, because changing employment patterns in two geographically connected counties clarifies the importance of the B\&O. By aligning themselves with industrial progress that was dependent upon wage labor in diversified occupations, Taylor County's interests began to shift away from a total reliance on agricultural trade.

Historians such as Kenneth Noe and John Shaffer have argued that livestock trade was the primary source of commerce in West Virginia that rose to any level of commercial enterprise, and farming occupations were predominant in both Barbour and Taylor counties in the 1850 and 1860 censuses. ${ }^{37}$ Census records from Taylor County reveal high numbers of railroad workers in 1860

\footnotetext{
${ }^{33}$ Citizens of Piedmont to John W. Garrett, May 7, 1861, letter, 1861-1863 West Virginia, 16.1.4 28, MS 2003, 383 (Baltimore, MD: HWRL).

34 John J. Binder, “The Transportation Revolution and Antebellum Sectional Disagreement," Social Science History, Volume 35, Number 1 (Spring 2011), 23.

${ }^{35}$ Link, 48.

${ }^{36}$ Shaffer, 8.

${ }^{37}$ Kenneth Noe, Southwest Virginia's Railroad: Modernization and the Sectional Crisis (Urbana, IL: University of Illinois Press, 1994), 36-37. Noe has argued that subsistence farming was the hallmark of the average West Virginia resident because it limited "the farmer's dependence on the local merchant or the national marketplace."

Shaffer goes a step further and claims that the lack of good internal transportation created a reliance on the livestock trade. Shaffer, Clash of Loyalties, 22.
} 
and corresponding higher numbers of immigrants working in railroad and its ancillary occupations. A comparison of the 1850 and 1860 censuses for Barbour and Taylor counties confirms that, after the B\&O line reached Grafton, Taylor County saw a much larger diversification of occupations, while Barbour County remained nearly exclusively agricultural in employment opportunities. While in 1850, farming jobs in Taylor County represented more than $85 \%$ of the working adult male population, that number had dropped to approximately $61 \%$ by 1860 , while Barbour County's 1860 farming occupations actually increased from $85 \%$ to $89 \% .{ }^{38}$ In fact, the wide diversity of employment seen in Taylor County after the B\&O came to town illustrates the vast influence that this employer had on the county.

\begin{tabular}{|l|c|c|c|}
\hline 39 & Total Employed & Farming Occupations & $\begin{array}{c}\text { Non-Farming } \\
\text { Occupations }\end{array}$ \\
\hline Barbour County 1850 & 2008 & 1778 & 230 \\
& & $88.55 \%$ & $11.45 \%$ \\
\hline Taylor County 1850 & 1556 & 1373 & 233 \\
& & $85.03 \%$ & 24.97 \\
\hline Barbour County 1860 & 2301 & 2056 & $10.65 \%$ \\
\hline Taylor County 1860 & & $89.35 \%$ & 742 \\
& 1901 & 1159 & $39.03 \%$ \\
\hline
\end{tabular}

Figure 7: $\quad$ Comparison of Farming versus Non-Farming Employment

Barbour and Taylor Counties, West Virginia - 1850-1860

Analyzing the way that the $\mathrm{B} \& \mathrm{O}$ shaped employment patterns in Taylor County is critical to understanding the ways that political relationships shifted at the local level. The influence of the $\mathrm{B} \& \mathrm{O}$ is important because it illustrates that there were not just two static political positions during the Civil War Era, instead there was a vibrant and shifting reliance on industries that serviced specific localities and transformed allegiance. Rural versus industrial and modern versus pre-modern analysis of Civil War sectionalism does not fit when one considers two geographically connected counties whose primary economic difference was the influence of the railroad. According to Aaron Marrs, the progress of improvements and advancements in transportation were nearly parallel in the North and the South, with little regard to political affinity. ${ }^{40}$ William Thomas' book and digital companion piece The Iron Way argues, however, that while both Union and

\footnotetext{
381850 Census of Taylor County, Virginia.

391850 Census of Barbour County, Virginia; 1860 Census of Taylor County, Virginia; 1860 Census of Barbour County, Virginia; 1860 Census of Taylor County, Virginia.

40 Aaron W. Marrs, "The Iron Horse Turns South: A History of Antebellum Southern Railroads," Enterprise \& Society, Volume 8, No. 4 (December 2007), 787.
} 
Confederate believed in the potential of the railroad system, they used the railroad as a means to extend their "contending territorial empires." 41 In the North, railroad companies utilized both local labor and Irish immigrants to build their lines and operate their machines, "the vanguard of a modern, systematized, large-scale labor force." ${ }^{, 42}$ The South did not fail to appreciate the importance of railroads to a market economy in which they wholly participated, but they used slave labor almost exclusively for all but a small portion of railroad jobs. ${ }^{43}$ The value of the railroad may have been shared, but the ideology behind its use was significant at the local, state, and national levels of conflict.

In this way, the experience of Barbour and Taylor County residents in response to the railroad mirrors the larger national experience with the railroad. Both northern and southern economies were influenced by the transformation that the railroad had on trade, labor, and transportation. West Virginia, thus, became part of a national experience of transformation based on the influence of the railroad industry that often shifted political allegiance. Ken Fones-Wolf notes that, within West Virginia, "questions about the state's economic future shaped the political divisions among West Virginians, realigning counties in conformity with the path of industrial development, not former loyalty to the Confederacy." ${ }^{44}$ John Binder argues that the railroad industry promoted itself for thirty years prior to the Civil War, by claiming that the railroad had the capacity to move the nation west and alleviate sectionalism through its mutually beneficial opportunities. ${ }^{45}$ Employment differences between individual counties, however, show that the railroad actually heightened differences that shaped political ideology.

The differences seen in Barbour and Taylor County can be related to the diverging trajectories that employment patterns took with the entrance of the B\&O. The railroad industry changed employment patterns across the United States and influenced the towns, counties, states and regions it entered. Employment patterns confirm that the $\mathrm{B} \& \mathrm{O}$ brought railroad-specific employment to Taylor County that was totally absent from Barbour County and it is clear that

\footnotetext{
${ }^{41}$ William G. Thomas, The Iron Way: Railroads, the Civil War, and the Making of Modern America (New Haven, CT: Yale University Press, 2011), 5.

The digital component to this work can be found at: http://railroads.unl.edu/images/.

42 Ibid., 45.

${ }^{43}$ Marrs, 787.

44 Ken Fones-Wolf, "A House Redivided From Sectionalism to Political Economy in West Virginia," in Reconstructing Appalachia, ed. Andrew L. Slap (Lexington, KY: University Press of Kentucky, 2010), 238. http://www.jstor.org/stable/j.ctt2jctwj.13.

${ }^{45}$ Binder, 46.
} 
Taylor County also saw an increase in jobs such as day laborers, carpenters, and blacksmiths, all jobs that were counted among the "[1] argest ten occupational categories for the Baltimore \& Ohio Railroad, 1857."46

\begin{tabular}{|l|c|c|c|c|c|}
\hline & $\begin{array}{c}\text { Total } \\
\text { Occupations }\end{array}$ & $\begin{array}{c}\text { Railroad } \\
\text { Occupations }\end{array}$ & $\begin{array}{c}\text { Day } \\
\text { Laborers }\end{array}$ & Carpenters & Blacksmiths \\
\hline $\begin{array}{l}\text { Barbour } \\
\text { County 1850 }\end{array}$ & 2008 & 0 & 0 & 4 & 44 \\
\hline $\begin{array}{l}\text { Taylor } \\
\text { County 1850 }\end{array}$ & 1556 & 12 & 0 & 14 & 19 \\
\hline $\begin{array}{l}\text { Barbour } \\
\text { County 1860 }\end{array}$ & 2301 & 0 & 0 & 6 & 32 \\
\hline $\begin{array}{l}\text { Taylor } \\
\text { County 1860 }\end{array}$ & 1901 & 82 & 130 & 67 & 46 \\
\hline
\end{tabular}

Figure 8: $\quad$ Comparison of Occupations

Barbour and Taylor Counties, West Virginia - 1850-1860

The railroad brought jobs and it brought immigrant labor, which further changed the demographics between Barbour and Taylor Counties. The 1850 Taylor County census shows large numbers of single men from Ireland living together in boardinghouses and performing work as laborers. $^{47}$ The 1850 Taylor County census lists the residence of James Reynolds as home to sixteen Irish men working as laborers, with several similar neighboring homes of Irish laborers. ${ }^{48}$ When William Robinson of Taylor County found himself in search of work in 1857, he found working on the McGuire Tunnel project, noting to his family that he found his Irish co-workers "very clean." ${ }^{49}$ Historian Matthew Mason has noted the importance of the Irish in the construction of railroads across the United States, identifying the steady labor as greatly desired by immigrants seeking full-time employment. ${ }^{50}$ The labor of these men in clearing track locations signifies that the presence of a railroad was felt for many years prior to an engine arriving at a station. Taylor County demonstrated large numbers of immigrants in both censuses considered, while Barbour County's working immigrant population never exceeded $10 \%$ during the 1850 and 1860 census

\footnotetext{
46 Thomas, 217.

471850 Census of Barbour County, Virginia; 1860 Census of Taylor County, Virginia; 1860 Census of Barbour County, Virginia; 1860 Census of Taylor County, Virginia.

481850 Census of Barbour County, Virginia; 1860 Census of Taylor County, Virginia; 1860 Census of Barbour County, Virginia; 1860 Census of Taylor County, Virginia.

${ }^{49}$ William Robinson to his “Sister," September 12, 1857, letter, Robinson Family Manuscript Collection, A\&M 2662 (Morgantown, WV: WVRHC).

${ }^{50}$ Matthew Mason, "Paddy vs. Paddy: Labor Unrest and Provincial Identities along the Baltimore and Ohio Railroad, 1849-1851," Transnational West Virginia: Ethnic Communities and Economic Change, 1840-1940, eds. Ken FonesWolf and Ronald L. Lewis (Morgantown, WV: West Virginia University Press, 2002), 8.
} 
count. ${ }^{51}$ Shaffer's total Barbour County immigrant counts over an eighty year period are less than half of Taylor County's immigrants in either 1850 or $1860 .^{52}$ Not only did immigrants come to Taylor County, they came specifically to work for the B\&O.

\section{Percentage of immigrant labor to total working men IN ALL OCCUPATIONS}

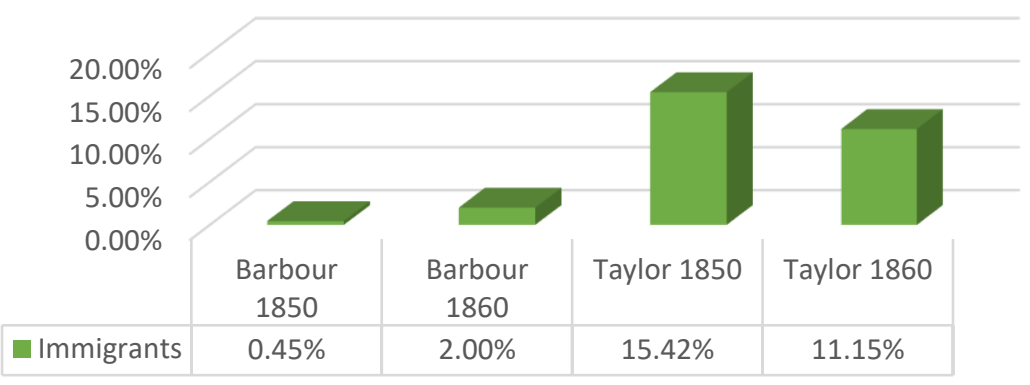

Figure 9: $\quad$ Comparison of Immigrant Employment Barbour and Taylor Counties, West Virginia - 1850-1860

While labor jobs were plentiful, employment by the $\mathrm{B} \& \mathrm{O}$ required adherence to company standards. Because company profits depended upon the bottom line and required that the trains be kept on tight and efficient schedules, conformity to standards was key to individual employment opportunities. While railroads originally relied upon boosters to advance their cause, as the industry expanded it relied less and less on individuals outside the control of the company, and began to establish clear channels of communication to monitor its westward interests. ${ }^{53}$ B.L. Jacob, writing to the Manger of Fuel Train, wrote from Grafton that his agents were authorized to hire as many hardworking men as required to efficiently keep the trains on track. ${ }^{54}$ Successful management of the railroads could have a serious effect on a small communities' market enterprises, and Jacob concluded a letter of April 8, 1858 with the caution: "[L]et yours be a model

\footnotetext{
511850 Census of Barbour County, Virginia; 1860 Census of Taylor County, Virginia; 1860 Census of Barbour County, Virginia; 1860 Census of Taylor County, Virginia.

52 Shaffer, 31.

53 James A. Ward, Railroads and the Character of America (Knoxville, TN: The University of Tennessee Press, 1986), 85 .

${ }^{54}$ B.L. Jacob to Mr. Harris, Manager of Fuel Train, April 8, 1858, letter, Baltimore and Ohio Railroad Records, A\&M 522 (Morgantown, WV: WVU WVRHC).

In the identification of the archival material, Mr. Jacob is simply identified as an employee of the B\&O Railroad, working and writing from Grafton, WV.
} 
train."55 In order to secure their own futures, Taylor County's railroad employees understood that they were required to "model" the expectations of the remote corporate center. Jacob, as a representative of the $\mathrm{B} \& \mathrm{O}$, cautioned that, should a man not adhere to the standards of behavior set forth by the company, "he may find it more difficult to get back his former place than he may now suppose." 56

The hierarchical relationship that existed in the world of industry reveals that leadership roles of those responsible for maintaining industry standards often resulted in some degree of "deference from those below them in the civic order." 57 As those in labor and trade positions looked to their community leadership for influence, they found themselves following those leaders in allegiance to the industry that supported the community. The subtle shift to subordination to a "distant corporate bureaucracy" contributed to a community that considered itself a piece of a larger body, rather than solely concerned with individual interests. ${ }^{58}$ The $\mathrm{B} \& \mathrm{O}$ had the power to shape the behavior of its employees from a central location that was geographically removed from those employees. This system of corporate control mimicked ancient governance through imperium, described by David Armitage as "authority in any form, detached from any particular holder of it." 59

Jobs and employment expectations were not the only shift in employment patterns, as the increased traffic of goods and materials across the railroad created additional opportunities for merchants and other commercial ventures. ${ }^{60}$ The close ties that the city of Grafton had to the $\mathrm{B} \& \mathrm{O}$ were visually evident, as the actual layout of the town was designed to service the railroad, including placement of the most prominent buildings at or near the $\mathrm{B} \& \mathrm{O}$ station. The relationship

${ }^{55}$ B.L. Jacob to Mr. Harris, Manager of Fuel Train, April 8, 1858, letter, Baltimore and Ohio Railroad Records, A\&M 522 (Morgantown, WV: WVU WVRHC).

${ }^{56}$ B.L. Jacob to Mr. Griffith, June 5, 1858, letter, Baltimore and Ohio Railroad Records, A\&M 522 (Morgantown, WV: WVRHC).

${ }^{57}$ Frank Towers, The Urban South and the Coming of the Civil War (Charlottesville, VA: University of Virginia Press, 2004), 23.

58 Jay Sexton, "Steam Transport, Sovereignty, and Empire in North America, circa 1850-1885," The Journal of the Civil War Era, Volume 7, Number 4 (December 2017), 638.

${ }^{59}$ David Armitage, The Ideological Origins of the British Empire (New York: Cambridge University Press, 2000), 30.

Armitage's discusses the term "imperium" as the Roman root of what later became the European model of empire from the sixteenth through the twentieth centuries. The term is relevant here in its application of the structure of a large corporation exerting control over remote satellite stations, and is equally relevant to the expansion of the United States in its westward trajectory.

${ }^{60}$ Frank J. Byrne, Becoming Bourgeois: Merchant Culture in the South, 1820-1865 (Lexington, KY: The University Press of Kentucky, 2006), 17. 
between the $\mathrm{B} \& \mathrm{O}$ and the citizens of Taylor County are further revealed in letters offering tracts to the $\mathrm{B} \& \mathrm{O}$ for railroad buildings. The Monongalia Mirror included a notice in its July 27, 1850 edition, with Sarah Fetterman offering for auction one-hundred-nineteen lots along the B\&O in Taylor County, advising that "in point of commercial importance its location is unrivalled." ${ }^{61}$ On April 21, 1853, James K. Smith wrote directly to B\&O President John Garrett that he could recommend a particular tract of land because the gentlemen offering the land for sale had previously been favorably associated with the $\mathrm{B} \& \mathrm{O} .{ }^{62}$ The $\mathrm{B} \& \mathrm{O}$ was, thus, perceived by the community as central to its economic success and the community pushed itself to conform to the needs of the $\mathrm{B} \& \mathrm{O}$.

The center of town was the railroad, and the town celebrated its connection to the industry that had taken a small community at Three Forks Creek and transformed it into Grafton. ${ }^{63}$ While there had been a small settlement at the location of Grafton, it was the B\&O that established the actual town when it set up its switching station and drew in opportunities for employment and business. ${ }^{64}$ As an active depot town, Grafton saw a significant surge in ancillary employment opportunities offered in restaurants, hotels, and shops to service travelers stopping at the station and a growing local population. ${ }^{65}$ David Hunter Strother, who was a member of the "Artists' Excursion" party that made the trip of the B\&O from Baltimore to Wheeling in 1857 reported that the party enjoyed overnight accommodations and meals in Grafton. ${ }^{66}$ Another indicator of the economic transition experienced by Taylor County is the increase in the number of merchantrelated jobs, which also significantly increased after the entrance of the B\&O. Barbour County's merchant category occupations remained static, while the growth of traffic resulting from the completed B\&O line corresponds to a large increase in those jobs in Taylor County. The small,

\footnotetext{
61 “Grand Sale of Lots," The Monongalia Mirror, July 27, 1850. Microfilm Collection, Morgantown, WV: WVU WVRHC.

62 James K. Smith to John W. Garrett, April 21, 1873, letter, Property at and Near Grafton, WV, 16.1.9, 75, MS2003, 4130 (Baltimore, MD: HWRL).

${ }^{63}$ Stover, 81.

${ }^{64}$ Paula Stoner Reed, "Grafton Downtown Commercial Historic District," National Register of Historic Places Nomination Form (Washington, DC: U.S. Department of Interior, National Park Service, September, 1983), https://npgallery.nps.gov/NRHP/AssetDetail?assetID=7731cacc-9057-433d-a6f3-11e646a49967.

651860 U.S. Census of Taylor County, Virginia.

${ }^{66}$ David Hunter Strother, writing as "Porte Crayon," "Artists' Excursion Over the Baltimore \& Ohio Rail Road," Harper's New Monthly Magazine, June 1859, accessed November 6, 2017, http://www.catskillarchive.com/rrextra/abboa.html.
} 
dusty community was transformed into the railroad town of Grafton, with residents now bound together by the need to foster the economic benefits that the B\&O brought through their hub. ${ }^{67}$

TOTAL OCCUPATIONS

\begin{tabular}{l|cc}
\hline BARBOUR COUNTY 1850 & & RELATED OCCUPATIONS $^{\mathbf{6 8}}$ \\
\hline TAYLOR COUNTY 1850 & 2008 & 13 \\
\hline BARBOUR COUNTY 1860 & 1556 & 29 \\
\hline TAYLOR COUNTY 1860 & 2301 & 15 \\
\hline
\end{tabular}

TOTAL MERCHANT AND RELATED OCCUPATIONS ${ }^{68}$
Figure 10: $\quad$ Comparison of Merchant and Related Occupations Barbour and Taylor Counties, West Virginia - 1850-1860

As those engaged in commercial activities sought to improve their own economic wellbeing, they realized that promoting the general welfare of their community could enhance their own potential. ${ }^{69}$ An increase in merchant-based occupations is often characterized by a focus on earning and economic development that drives an area closer to the ideology of the industry that services its region. ${ }^{70}$ After the $\mathrm{B} \& \mathrm{O}$ tracks reached Ohio in 1853, a grand celebration tour was arranged in 1857 to transport railroad officials and dignitaries along the line to observe the miraculous technology, stopping at the junction at Grafton. In the manuscript prepared to commemorate the transformative qualities the $\mathrm{B} \& \mathrm{O}$ had on its landscape, William Prescott Smith noted that the small town had been born: "[t]hough young yet, it bears upon its face the evidence of progress and prosperity, promising to become at some day much more important place than it is at present." $" 71$ Taylor County was no longer an isolated, rural community; it was a link in the national chain of progress laid by the $\mathrm{B} \& \mathrm{O}$.

Because Barbour County did not lay on the main line of the B\&O, the influence of the railroad industry and its ancillary opportunities is much reduced when compared to Taylor County. While neighboring Taylor County had a strong railroad presence, Barbour County's early history

\footnotetext{
${ }^{67}$ L. Diane Barnes, “Booster Ethos: Community, Image, and Profit in Early Clarksburg," West Virginia History Volume 56 (1997), accessed September 8, 2017, http://www.wvculture.org/history/journal_wvh/wvh56-2.html.

${ }^{68}$ For this study, per Walbert's model, merchant-related jobs include hotel, grocery, boardinghouse, and tavern keepers, as well as merchants.

69 Byrne, 49.

70 Ibid., 15.

71 Smith, 164.
} 
makes scarce mention of the railroad. ${ }^{72}$ Without the presence of the B\&O, Barbour County was less connected to northern and western market interests and, consequently, allegiance to Virginia in 1861 was not as complicated by economic factors. Unlike Taylor County, Barbour County was late to the railroad expansion that was sweeping the nation and remained almost exclusively reliant upon farming for income. The county heavily lamented its lack of transportation improvement, but Philippi Plaindealer editor D.W. Gall continued to associate the railroad industry with an ideology believed to be in opposition to the county's politics: "[w]hile monopoly in some parts is sucking the life-blood from enterprise and improvement, we should lend our mightiest efforts to quell such an imposition on the people."73 Railroads were, in the minds of Barbour County, part of a force that worked against the rights of individual landowners.

The first effort to construct a railroad line to Barbour County did not begin until 1882, when the public-privately funded Grafton and Greenbrier line (GGR) began construction, a proposition that proceeded slowly until the B\&O took over the line in $1891 .^{74}$ The GGR was headed by Samuel Woods, a prominent Barbour County attorney and judge, who had been a delegate to the Virginia convention of 1861 and a staunch Confederate supporter during the Civil War. ${ }^{75}$ While Woods believed in the need for the infrastructure benefits of railroads, he objected to the influence of big business. Woods and his family strongly opposed the influence of the $\mathrm{B} \& \mathrm{O}$ and railed against Barbour County conceding sale of their private shares to the industry giant when the GGR was unable to meet loan obligations, with son Samuel V. Woods writing to his local editor: "Do you dare look your constituents in the face and say you do not control this road through your county proxies for the benefit of the Baltimore \& Ohio Company?"76 Woods valiantly expressed a voice of independence and resistance to the perceived heavy-hand of empire that lived in the mountains in the form of railroad expansion: "[w]e all desire to see the road extended South through this county, but we are not quite ready to bow down and worship the Iron God of the

\footnotetext{
${ }^{72}$ Hu Maxwell, The History of Barbour County, West Virginia: From its Earliest Exploration and Settlement to the Present Time (Morgantown, WV: The Acme Publishing Company, 1899), 198-236.

73 "Friday," Philippi Plaindealer, February 21, 1874. Microfilm Collection, Morgantown, WV: WVU WVRHC.

74 Barbour County Historical Society, Mrs. Hu C. Myers, "Philippi B\&O Railroad Station" National Register of Historic Places Nomination Form (Washington, DC: U.S. Department of Interior, National Park Service, November 25, 1985), https://npgallery.nps.gov/NRHP/AssetDetail?assetID=a007ba3a-3aee-4c07-ac8a-d1f6bae29553.

${ }^{75}$ Maxwell, 491-493.

${ }^{76}$ Samuel V. Woods, "G. \& G. R.R.: An Argument in Favor of a Sale of Our Stock in the Road," Philippi Plaindealer, June 24, 1886, Samuel Woods Family Papers, A\&M 1111 (Morgantown, WV: WVRHC).
} 
Baltimore \& Ohio Rail Road Company."77 Without the presence of the B\&O in Barbour County, connection to that economic influence was lost upon residents who still clung to their Virginia roots.

Barbour County had a more visible Confederate presence than did Taylor County, and its population was more evenly divided in political sentiment, with 718 Unionists and 529 Confederates serving during the war. ${ }^{78}$ Union supporters in Barbour County were slow to join, often having to travel to a neighboring county to find a regiment for enlistment. ${ }^{79}$ Barbour County was unable to organize a single volunteer company for Union Service and the strong Confederate sentiment in Barbour County kept Union sympathizers underground and unable to formally organize in support of the North. ${ }^{80}$ In some areas, such as the Cove District of Barbour County, it was rumored that efforts to organize Union troops raised only four men for service. ${ }^{81}$ Many prominent Barbour County community figures served the Confederacy, including three of the seven attorneys who were listed in the 1850 Barbour County census, including county prosecutor Daniel Auvil. ${ }^{82}$ Not only were powerful citizens associated with the Confederate movement in Barbour County, there was a threat that physical harm could come to Union supporters. ${ }^{83}$ During Barbour County public debates on the issue of secession, attorney Spencer Dayton, speaking on behalf of the Union, was removed under gunpoint from the proceeding by his fellow Barbour Countians. ${ }^{84}$ Several prominent and wealthy Confederate soldiers left Barbour County entirely during the Civil War period, including county prosecutor, Daniel Auvil, who moved to McDowell County in the southern part of the state, and Henry Auvil, who moved to Pendleton County, bordering Virginia. ${ }^{85}$ Barbour County recollections of the Civil War period were not that they had been isolated from the national transition to a railroad economy, but were consistent with

\footnotetext{
${ }^{77}$ Samuel V. Woods, “G. \& G. R.R.: An Argument in Favor of a Sale of Our Stock in the Road,” Philippi Plaindealer, June 24, 1886, Samuel Woods Family Papers, A\&M 1111 (Morgantown, WV: WVRHC).

78 John Shaffer, Union and Confederate Soldiers and Sympathizers of Barbour County, West Virginia (Baltimore, MD: Clearfield Company, Inc., 2005), 2.

${ }^{79}$ Shaffer, Clash of Loyalties, 71.

80 Ibid., 59.

${ }^{81}$ L.D. Morrell to Samuel Woods, June 29, 1861, letter, Samuel Woods Family Papers, A\&M 1111 (Morgantown, WV: WVRHC).

82 Shaffer, Union and Confederate Soldiers, 128, 132-133, 207.

83 Maxwell, 245.

84 Ibid., 240.

${ }^{85}$ Shaffer, Union and Confederate Soldiers, 128.
} 
traditional Lost Cause ideology that their county's suffering was due to the fact that its prominent Confederate citizens had fled for the South and the town had yet to recover its former glory. ${ }^{86}$

Like Barbour County and many other counties in West Virginia, Taylor County also had a portion of the population that favored the Confederacy. Walter Rohrbacher and John Shaffer hypothesize that the elite families of both Taylor and Barbour held allegiance to the Confederacy. ${ }^{87}$ Elite men who worked in either professional jobs or owned farms were less dependent upon diverse employment opportunities offered by the $\mathrm{B} \& \mathrm{O}$ and, as Barbara Rasmussen has noted, "a class of wageworkers was unlikely to arise from independent farmers." ${ }^{88}$ Conversely, in an economy increasingly dependent upon the $\mathrm{B} \& \mathrm{O}$ labor jobs and ancillary employment opportunities around which Taylor County revolved, Confederate ideology held less sway. Rohrbacher notes that, of the Confederates in Taylor County who joined the Letcher Guards, only three came from Grafton where the railroad yard was located. ${ }^{89}$ While Confederates were outliers in Taylor County, in Barbour County, the opposite was true, where men wishing to enlist in the Union Army had to make their way to Grafton..$^{90}$ Ultimately, both Taylor and Barbour counties sent a company of men to serve the Confederacy, but the Grafton area of greatest B\&O influence saw virtually no Confederate activity.

In Barbour County a letter to Confederate sympathizer Samuel Woods advised that the Union men of Barbour County were reduced to holding "secret meetings" in order to keep their allegiance hidden from their neighbors. ${ }^{91}$ Confederate activity was tempered in Taylor County and, as the war wore on, correspondence to Fetterman resident and Confederate Helen Robinson, cautioned that the younger residents of Taylor County were increasingly patriotic for the Union. ${ }^{92}$ Taylor County's Confederates stationed away from home also recognized the shifting state of

\footnotetext{
86 “Philippa," Philippi Plaindealer, December 20, 1873. Microfilm Collection, Morgantown, WV: WVU WVRHC.

${ }^{87}$ Walter Rohrbacher, “A History of the Letcher Guards and the Twenty-Fifth Virginia Infantry Regiment” (MA Thesis, West Virginia University, 2005), 17.

Shaffer, Clash of Loyalties, 34.

${ }^{88}$ Rasmussen, Barbara, Absentee Landowning and Exploitation in West Virginia, 1760-1920 (University Press of Kentucky, 1994), 59. http://www.jstor.org/stable/j.ctt130jqj0.

${ }^{89}$ Rohrbacher, 18.

${ }^{90}$ Shaffer, Clash of Loyalties, 70.

${ }^{91}$ Unidentified Confederate sympathizer to Samuel Woods, undated, letter, Samuel Woods Family Papers, A\&M 1111 (Morgantown, WV: WVU WVHRC).

92 "Loving Brother Lee" to Helen Robinson, November 7, 1864, letter, Robinson Family Manuscript Collection, A\&M 2662 (Morgantown, WV: WVU WVRHC).
} 
affairs in their county, with John Robinson, reporting to his brother that " $[\mathrm{w}]$ ith few exceptions the people of this county are for the Union." 93 In terms of the political breakdown in the two counties, while the vote on secession for Taylor County has been lost, the town of Grafton: "recorded only one secessionist vote." 94 Barbour County's vote on the secession issue was fairly evenly split, with 857 pro-secession and 626 pro-Union. ${ }^{95}$ Confederates who remained in Barbour County believed themselves preyed upon by the Union soldiers sent to keep the peace, characterizing their fellow West Virginians as "strangers who have come here to devour \& destroy what little is left."96 Taylor's Confederates did not have a majority vote, while Barbour was one of the "eleven Northwestern counties...(who) approved the Secession Ordinance and militantly opposed the dismemberment of the commonwealth." 97

Taylor County's connection to the $\mathrm{B} \& \mathrm{O}$ is reflective of the larger process of forming a state within parameters that favored the $\mathrm{B} \& \mathrm{O}$. Once the statehood vote in 1861 confirmed that West Virginia could begin the formal process of structuring their government, West Virginian politicians and businessmen, aware of the limitations that the Virginia legislature previously had on potential for economic growth, sought to develop a government based on the economically viable environments they saw in Pennsylvania and Ohio and made efforts to structure the new state government in favorable terms for economic development. ${ }^{98}$ Many delegates to the state Constitutional proceedings at Wheeling in 1861 firmly believed that the needs of the $\mathrm{B} \& \mathrm{O}$ were linked with the needs of the new state. ${ }^{99}$ The trajectory of the new state was wholly aligned with its connections to the $\mathrm{B} \& \mathrm{O}$, and they intended to "have every rod of that great improvement within the lines of this new State."100

When discussion turned to the issue of which counties of western Virginia to claim, Delegate Van Winkle composed editorials, which he forwarded to B\&O President Garrett, advising "the great majority of our constitutional convention desired to include them (Jefferson

\footnotetext{
93 J.M. Robinson to his "Dear Brother," June 20, 1861, letter, Robinson Family Manuscript Collection, A\&M 2662 (Morgantown, WV: WVU WVRHC).

${ }^{94}$ Link, 52.

${ }^{95}$ Rohrbacher, 15.

96 "Sister" to Isabella Woods, April 8, 1863, letter, Robinson Family Manuscript Collection, A\&M 1111 (Morgantown, WV: WVRHC).

97 Curry, 48.

${ }^{98}$ Adams, 191.

${ }^{99}$ Ibid., 216.

${ }^{100}$ Ambler, Convention, 426.
} 
and Berkley counties), in order that the Baltimore and Ohio Railroad might lie wholly within the States of Maryland and West Virginia."101 Calling upon philosophies of the laws of nation, Delegate Brown directly invoked both Emer de Vattel and prior action of the United States as precedent for crafting an ordinance to force inclusion of the "few counties immediately contiguous to the Baltimore and Ohio Railroad," no matter their intent concerning joining West Virginia. ${ }^{102}$ Taylor County's delegate to the First Constitutional Convention of West Virginia, Harmon Sinsel served on the Committee on the Legislative Department, and voiced approval for the right of the legislature to force counties into the state of West Virginia. His position was that legislators had been appointed to act in the best interests of the new state, and individual county votes on inclusion were not required. Sinsel also specifically noted that, for the counties of Craig, Giles, Bland, Tazewell, Russell, Lee and Scott, if they were not forced into the state of West Virginia, they would likely stay with Virginia because they were in the geographical position to have access to the Virginia and Tennessee Railroad. ${ }^{103}$ As Sinsel pointed out, counties who had transportation access would have no need to join with a state that relied on the more western railroad system of the B\&O. These Virginia counties ultimately were not included in the state of West Virginia, but the counties connected to the B\&O, who were believed to be able to "aid in the development of that wealth and make it useful to bring in revenues to the State" were included. ${ }^{104}$

The state-makers who met at Wheeling, Virginia in 1861 to craft the Constitution recognized that the state was unmatched in resources for extraction, but lacked the capital required to transform the mountains into "the pathway of progress" envisioned by Delegate Stevenson of Wood County, Virginia. ${ }^{105}$ In many ways, the delegates at the convention believed that the B\&O held the only viable key to this progress:

In this way, sir, I apprehend the fostering of the Baltimore and Ohio Railroad and its connections becomes an interest to every one of the citizens of the present and proposed limits of the new State. It is something, sir, towards the interests of that road - and which cannot be so well understood by members who have not been so

\footnotetext{
${ }^{101}$ Peter Van Winkle, Wheeling Intelligencer, September 4, 1865, published letter, 1861-1865 West Virginia, 16.1.4, 28, MS2003, 383 (Baltimore, MD: HWRL).

102 Ambler, Convention, 218-219, 428-429.

Vattel's substantive relevance to the Convention was his belief that those who would not take advantage of the opportunity presented to them not only harm themselves, but harm their fellow men and, thus, do not deserve the same rights. Pagden, 78-79.

103 Ambler, Convention, 283-284.

104 Ibid., 326.

105 Ibid., 327.
} 
directly connected with it as many of you have - but it will be a great thing for the interest of that road whenever it finds itself in the hands of friends. ${ }^{106}$

There was no question, the $\mathrm{B} \& \mathrm{O}$ was central to the success of West Virginia and the delegates responsible for crafting state boundaries refused to accept anything less than complete inclusion of the land through which the $\mathrm{B} \& \mathrm{O}$ travelled, even if inclusion by force through the principles of empire was required.

Not only were residents of West Virginia dependent upon the pathways to eastern and western markets that the $\mathrm{B} \& \mathrm{O}$ could provide, the embryotic state had a distinct advantage for the $\mathrm{B} \& \mathrm{O}$ in its opportunity to create a tax structure that might make West Virginia an appealing economic prospect for the B\&O. Delegate Waitman Willey intimated as much when he spoke to his fellow delegates at the WV Constitutional Convention in 1861, advising that a favorable tax structure for the B\&O was essential to the success of West Virginia. ${ }^{107}$ West Virginia valued and coveted the B\&O's presence, and the B\&O was vested in the creation of a thoroughfare with favorable tax protections that West Virginia could offer. Representatives of the B\&O haunted the halls of debate in Wheeling, reporting back to B\&O President John Garrett to suggest ways to manage a storm brewing to collect taxes incurred by the $\mathrm{B} \& \mathrm{O}$ during the nebulous period prior to West Virginia's formal statehood. ${ }^{108}$ B\&O interests were also not harmed when Francis Pierpont, former local attorney for the B\&O in Marion and Taylor Counties, was elected to serve as the governor of the "Restored" State of Virginia prior to West Virginia's official recognition as a separate state. ${ }^{109}$ While statehood meant that West Virginians could embark on improvements that ensured their connection to western markets, they originally committed to tax structures and legislation that would make their market hospitable to the $\mathrm{B} \& \mathrm{O} .{ }^{110}$ The $\mathrm{B} \& \mathrm{O}$ sent representatives to the convention, and received correspondence from the offices of competing railroads, who were interested in protecting the common interest of favorable tax structure in West Virginia.

Twenty years after the Civil War and statehood, Grafton continued to display its reliance on the $\mathrm{B} \& \mathrm{O}$, and its paper advertised three daily stops in their town for travelers wishing to depart

\footnotetext{
106 Ambler, Convention, 354-355.

107 Ibid., 438.

108 B. Despard to John W. Garrett, February 25, 1866, telegram "B\&O Railroad Earnings and Expenses, Main Stem," Taxes in West Virginia (excepting Hampshire County), 16.1.4, 28, MS 2003, 1517 (Baltimore, MD: HWRL).

${ }^{109}$ Charles Ambler, Francis H. Pierpont: Union War Governor of Virginia and Father of West Virginia (Chapel Hill, NC: The University of North Carolina Press, 1937), 28.

110 Adams, 191.
} 
for "all points in the WEST, Northwest \& Southwest." and dependable, but Taylor County residents were assured by the paper that the growing competition among aspiring railroad ventures could only add to vital business opportunities. ${ }^{112}$ The presence of the $\mathrm{B} \& \mathrm{O}$ in Grafton made it a profitable business location, made it a hub for travelers, and presented investment opportunities for businessmen wishing to invest in smaller railroads that were proposed across the area to connect to the $\mathrm{B} \& \mathrm{O}$ line. Other remote and interior counties recognized the potential of the financial opportunities that these smaller lines could have, and the Grafton Eagle frequently noted the growing impatience of towns seeking lines from Grafton. ${ }^{113}$ Relationships between large railroad interests and state government would open up untapped areas of immense coal deposits that became marketable with a means to transport the coal to markets across the nation. ${ }^{114}$ Henry Brannon, writing from Weston, West Virginia, wrote to a business associate that he hoped to establish a line to connect to the $\mathrm{B} \& \mathrm{O}$ in order to access coal, oil, and timber as yet unmined. ${ }^{115}$ Taylor County had the good fortune to hold the center of the state's access to the $\mathrm{B} \& \mathrm{O}$, from which other parts of the state hoped to extend.

While Barbara Rasmussen posits that the "future link between industry and state government" was formed before 1840, the presence of the B\&O in West Virginia changed the economy of that area and contributed to shifting the balance of sectionalism that ultimately resulted in the creation of a state that began its life wholly favorable to railroad interests. ${ }^{116}$ As the railroad industry relentlessly pushed itself westward to meet growing demands and opportunities for a market economy beyond the boundaries of the eastern seaboard, the country through which it moved would be forever transformed. The entry of the $\mathrm{B} \& \mathrm{O}$ into West Virginia as an integral cog in the wheel of state-making changed local employment opportunities and changed the relationship between industry and government. As Richard White notes, the line between industry and politics became blurred when politicians became singularly invested in the success of railroads, and West

\footnotetext{
${ }^{111}$ The Grafton Eagle, April 4, 1884. Microfilm Collection, Morgantown, WV: WVU WVRHC. 112 Ibid.

113 “They Want a Railroad Bad,” The Grafton Eagle, April 18, 1884. Microfilm Collection, Morgantown, WV: WVU WVRHC.

114 Adams, 210-212.

${ }^{115}$ Henry Brannon to Robert H. Waters, Esq., August 4, 1873, letter, Henry Brannon, Lawyer, Papers, A\&M, 3116 (Morgantown, WV: WVU WVRHC).

${ }^{116}$ Rasmussen, 68.
} 
Virginia's experience is no exception. ${ }^{117}$ The relationships of men such as Peter Van Winkle and Francis Pierpont to the railroad industry during the time those men were charged with crafting the foundational documents of a critical Border State speaks to the blurring of the line that separated business and government. ${ }^{118}$ The influence of the $\mathrm{B} \& \mathrm{O}$ is seen at the basic county level in shifting employment patterns; it is seen at the state level, where its rail lines were deemed critical to the success of West Virginia and where it received favorable taxation structure; it is seen at the national level, as the tracks moved westward with an expanding nation.

The control with which distant businesses attended the outposts that drove their industry shifted the local from independent farmers to employees bound to adhere to standards required to make every mile of track profitable. ${ }^{119}$ Taylor and Barbour County are examples of the ways that shifting demographics at the local level can cause seismic shifts throughout a state and, Jay Sexton notes: "new steam routes and systems led to the creation of innovative imperial formations premised on the complex interactions among steam companies, national governments, and local actors." 120 The movement of the B\&O through West Virginia was the result of the nexus of an industry and political actors, and the economic occupational transformation that the B\&O brought to Taylor County was pivotal to shifting political allegiance in a divided region. The local changes wrought by the $\mathrm{B} \& \mathrm{O}$ were part of a larger shift of national ideology that increasingly focused the nation's field of vision west with echoes of empire.

\footnotetext{
${ }^{117}$ Richard White, Railroaded: The Transcontinentals and the Making of Modern America (New York: W.W. Norton \& Company, 2011), xxviii-xxix.

${ }^{118}$ The scope of this thesis does not extend to how industry and the federal government benefitted from the connection between West Virginia's government and the B\&O.

${ }^{119}$ White, $\mathrm{xxx}$.

120 Jay Sexton, "Steam Transport, Sovereignty, and Empire in North America, circa 1850-1885," The Journal of the Civil War Era, Volume 7, Number 4 (December 2017), 623.
} 


\section{CHAPTER FIVE: CONCLUSION}

West Virginia began its life as a part of the Old Dominion, a state whose very existence brings to mind the birth of a nation founded upon principles of republican independence. The process by which West Virginia became a separate state can similarly be seen as part of the birth of a nation - a new nation, formed by violent war and born within a complex series of ideological shifts. One of the most pronounced shifts in the nation was the shift away from republican identity rooted in self-sufficiency and toward an ideology of empire that encouraged industrial growth, westward expansion, and a cooperation between the federal government and business that would forever change economic opportunities in the United States. With its foundation based in securing the advancement of political elites and the industries to which those elites were connected, West Virginia's citizenry began an internal struggle to survive among timber companies, coal and oil extraction companies, and the extensive reach of the railroad industry.

Sean Patrick Adams identifies the Civil War as a "revolutionary event," not only because of the social and civil rights changes that occurred in the United States, but also because of the shifting of the place of industry and capitalism in the national lexicon. ${ }^{1}$ West Virginia is relevant to a discussion of this pronounced Civil War era shift, as its very creation was part of the merging of industry and government that contributed to the new direction of the nation. While the state of West Virginia was not isolated in the increase of corporations and an increase in legislation that offered protection and influence to industrialists, it is important that the state's foundation created limitations from which it has never fully recovered. The influence of outside businesses and the reliance upon extracted wealth left the West Virginian who attempted to support his family through small farming or artisanal craftsmanship with limited resources. The nation was moving toward a western expanse and toward federal government policy that privileged industry as an entity that could produce items ripe for taxation. The increasing number of out-of-state business charters issued by West Virginia was representative of its willingness to put the needs of citizens below those who contributed to the ideology of empire:

\footnotetext{
1 Sean Patrick Adams, "Soulless Monsters and Iron Horses: The Civil War, Institutional Change, and American Capitalism," in Capitalism Takes Command: The Social Transformation of Nineteenth-Century America, edited by Michael Zakim and Gary J. Kornbligh (Chicago: The University of Chicago Press, 2012), 249.
} 
This was not only an indication of the new flexibility given corporations crossing state lines but signaled the reliance of resource-rich, capital-poor states on the financial assets of outside interests. In states hoping to quickly develop their resources at the war's conclusion, there was an important role for out-of-state corporate actors, which would have been highly unlikely in the antebellum decades. ${ }^{2}$

Not only is West Virginia pertinent to the shifting ideologies that were happening across the nation, but Adams characterizes the state as the "most tangible example of the relationship between states and American capitalism" during the Civil War era. While the history of the state has been thoroughly examined by historians, the prominence of the concept of ideology of industry and empire in statehood formation is ripe for exploration. This work has examined several industrialists and a specific area that serve as examples of the powerful but quiet ways that industry influenced the creation and growth of the state. There remain many stories to be told about West Virginia's creation and the internal struggles of identity that took place across the state.

The national shift toward recognition and utilization of natural resources is directly reflected in the Lincoln administration's growing use of statistics that could monetize the United States "and its inhabitants - as one big capitalized investment." 3 The ability to analyze, conceptualize, and monetize natural resources existed in both the Union and Confederate governments, but decisions at the federal level to ensure the ability to collect much-needed federal revenue joined government to industry in the North in a way that significantly shifted the nature of employment at the local level. ${ }^{4}$ In West Virginia, the capital investments that the political elite devoted to land acquisition points to their vision of the state as a potential for economic and political growth and success. The railroad industry figured prominently in the shift to institutionalized capitalism that resulted in pronounced changes across the nation, and was so influential to West Virginia's creation that railroad lines were critical to the boundary formations of the state. As Steven Stoll posits, the very nature of capitalism requires "constant expansion into new environments, absorbing new people in order to increase its rate of profit." 5 West Virginia represented an opportunity for the United States to move a valuable piece of geography and natural resources away from the agrarian arena and opened an opportunity for industrialists and political

\footnotetext{
2 Adams, "Soulless Monsters and Iron Horses, 273.

3 Cook, 187.

${ }^{4}$ Hogeland, 53.

5 Stoll, 29.
} 
elite to participate in the securing of those resources for the national good. What was lost along the way, however, was the identity of a mountain people who became dependent upon the industrial movement and who were forced to either shift their ideologies to align with the industry of their area or engage in guerilla warfare and violence to fight those industries. The post-war period saw ongoing conflict between industrialists and individual landowners, and saw sweeping political changes that ushered former Confederates back into the political elite. The power of industry, however, maintained a hold on West Virginia that survived many political shifts.

This work has examined the thread of shifting ideology throughout West Virginia's statehood process by examining the pronounced investment in industry that swept across the nation in the Civil War era. The extensive web of political and economic connections woven by the political elite who crafted the mechanism by which the state was created connected those men to extensive out-of-state industrial processes that removed West Virginia's economic potential from its citizens. This history remains relevant in a region and state that has failed and continues to fail to provide its citizens with economic prosperity through the use of the state's natural resources and productive labor. Periods of economic prosperity throughout the state are punctuated by mining disasters, industrial spills, and workers' compensation policy that continues to privilege industry over individual rights. William Robbins' examination of the impact of the United States' policy of colony and empire creation opines that Appalachia has been wholly unable to attain economic equality with its neighboring state, despite ongoing federal assistance. ${ }^{6}$ Wilma Dunaway, among other historians, points to the historic practices of non-resident use of West Virginia resources as a means to create capital and profit, while failing to sustain the development of infrastructure to sustain the local and regional population. ${ }^{7}$ A recent CNBC report places West Virginia as dead last in its ranking of the worst states for business in terms of failure to diversify and provide economic opportunities for its citizens, with that report also citing the state as having one of the least educated populations in the nation. ${ }^{8}$ With an early history that is replete with examples of politicians and businessmen touting the unlimited natural resources of the state, and an ongoing

\footnotetext{
6 Robbins, 16.

7 Dunaway, 51-86.

${ }^{8}$ Scott Cohn, "In an Economic Death Spiral: West Virginia is America's Worst State for Business in 2017," accessed on March 30, 2018, https://www.cnbc.com/2017/07/11/west-virginia-americas-worst-state-for-business-in2017.html.
} 
failure to use those resources to the advantage of a working citizenry, West Virginia's future remains cloudy.

In December 1849, the Monongalia Mirror reprinted a letter from the Spirit of Jefferson, warning the public that no more time should be wasted in failing to embrace stock opportunities for the construction of the Baltimore \& Ohio Railroad (B\&O): "Too many years have already been permitted to pass away, which bear and record of the inactivity of this people in regard to this great work; it is worse than useless, however, ever to grieve over the past, let them regard the present - and deal with men and things as they find them now, and look to the future." ${ }^{9}$ West Virginia's history is the history of the promise of future economic successes rooted in industrial westward progress. American nationalism and the ways in which that nationalism was influenced by allegiance to a state, by allegiance to self, and allegiance to global industrial forces is a broad history. Allegiance to the interests of independent West Virginians is countered by the complex web of political and business ties that created the underpinning of the statehood process. The events that surrounded the fragmentation of the state of Virginia are critical to an understanding of ongoing issues such as the failure to thrive of West Virginia, and the continuing tightrope balancing of local, state, and federal powers.

West Virginia must recognize the depth of its dependence upon outside industrial forces in order to break the chains of economic underperformance that have held the state captive throughout its existence. By analyzing the impact that a particular industry, the B\&O Railroad had on the area of Barbour and Taylor Counties, it becomes clear that a region can be transformed by the power of the industry that utilizes that region. Through census data, the degree to which employment demographics shifted along the lines of the $\mathrm{B} \& \mathrm{O}$ is profound. What is equally profound, however, is the residue of a community that allows itself to be so completely transformed by an industry when that industry itself ultimately abandons the community. Without a sense of self, without an infrastructure to support a community, and without government resources to change its identity, when the B\&O leaves town, a community such as Grafton becomes a ghost town; a state such as West Virginia becomes merely the shadow of an empire.

\footnotetext{
${ }^{9}$ Monongalia Mirror, December 22, 1849.
} 


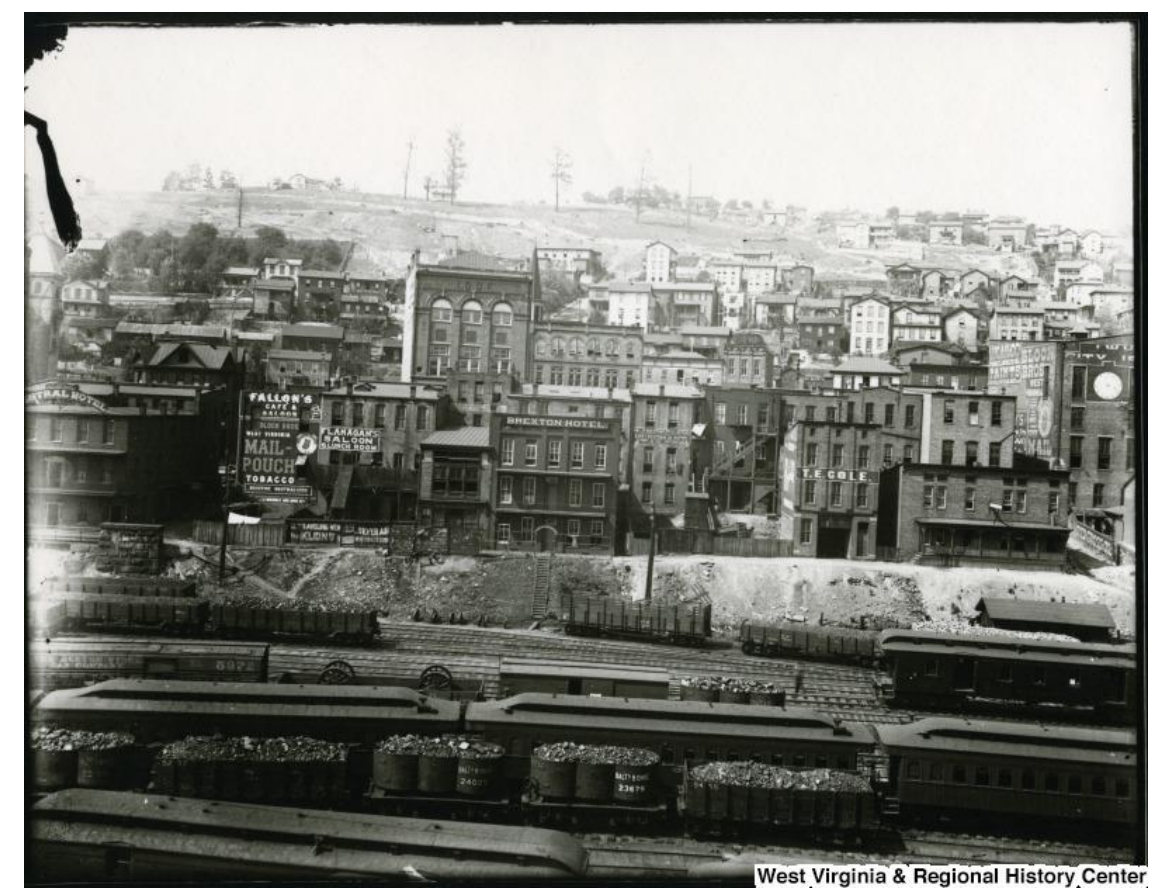

Figure 11: View of Grafton, WV, circa 1890, showing the Baltimore and Ohio Railroad yards. Note the evidence of active mercantile business facing the yard.

WV History OnView. West Virginia and Regional History Collection West Virginia University Libraries

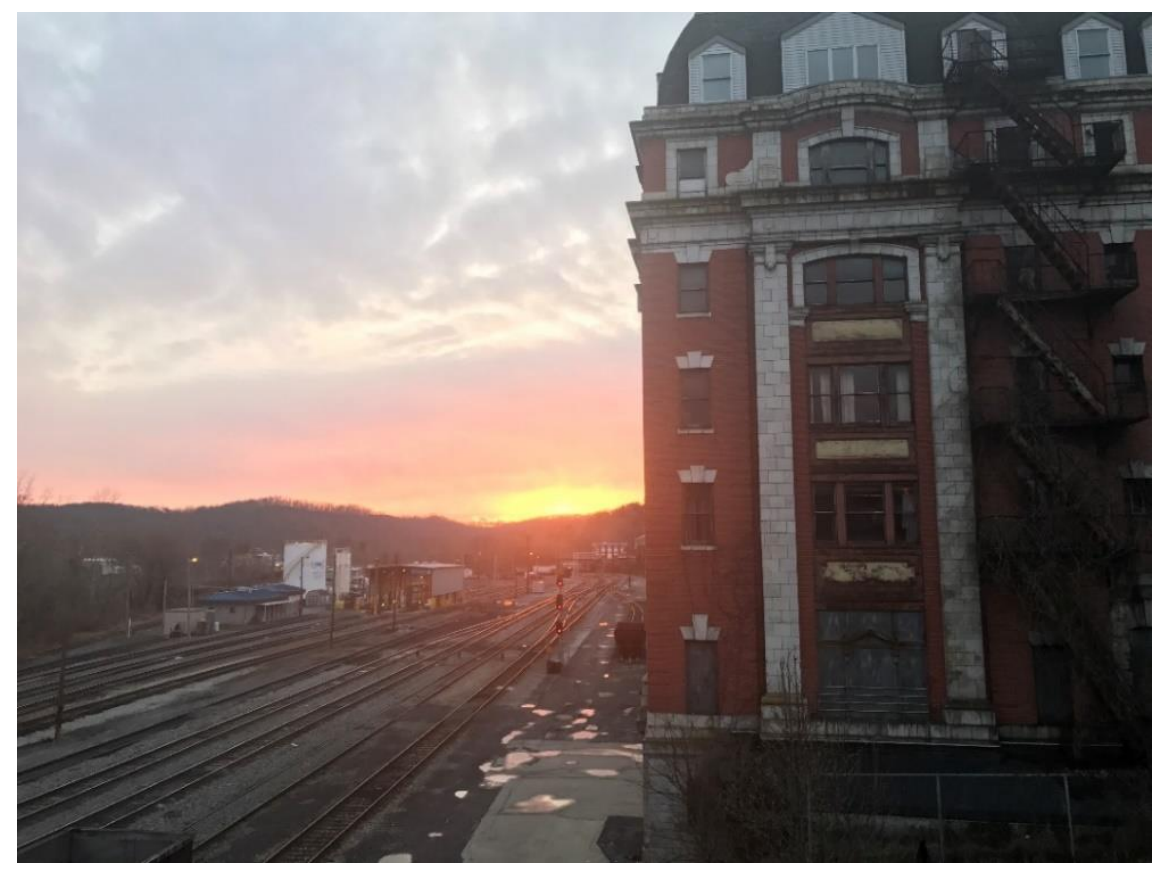

Figure 12: The sun setting on the abandoned Willard Hotel and B\&O Railroad yard in Grafton, WV. Author's photo, March 30, 2018 


\section{BIBLIOGRAPHY}

\section{$\underline{\text { Primary Sources }}$}

“1861-1865 West Virginia.” 16.1.4, 28 MS 2003, 383. Baltimore, MD: Hays T. Watkins Research Library of the Baltimore \& Ohio Railroad Museum Archives.

"An ACT to authorize the Baltimore and Ohio railroad company to complete their road through Virginia to the Ohio river, and for other purposes." Acts of the General Assembly of Virginia: Passed at the Session Commencing December 2, 1844, and ending February 22, 1845, in the Sixty-Ninth Year of the Commonwealth (Richmond, VA: Samuel Shepherd-Printer to Commonwealth-1845), 69. Accessed October 15, 2017 https://babel.hathitrust.org/cgi/pt?id=njp.32101073363267;view=1up;seq=77.

Ambler, Charles H., Atwood, Frances Haney, and Mathews, William B. Debates and Proceedings of the First Constitutional Convention of West Virginia (1861-1863). Huntington, WV: Gentry Brothers, Printers, 1863.

Baltimore And Ohio Railroad Company. [Map of the county west of Cumberland towards the Ohio river, showing the various lines surveyed or reconnoitred sic for the extension of the Baltimore $\&$ Ohio Rail Road to its western terminus referred to in the report of the chief engineer of September 20th, 1843]. [N.P, 1843] Map. Library of Congress. Accessed October 29, 2017, https://www.loc.gov/item/98688590/.

Baltimore and Ohio Railroad Records. Archives and Manuscript Collection Number 0522. Morgantown, WV: West Virginia Regional and History Center.

Brannon, Henry, Lawyer, Papers. Archives and Manuscript Collection Number 3116.

Morgantown, WV: West Virginia Regional and History Center.

Braxton County, West Virginia Land Book 1836-1854. Sutton, WV: Braxton County Courthouse.

Braxton County, West Virginia Land Book, 1872. Sutton, WV: Braxton County Courthouse.

Camden, Gideon D. (1805-1891) Papers. Archives and Manuscript Collection Number 1188. Morgantown, WV: West Virginia and Regional History Center.

Camden, Johnson Newlon Collection. Archives and Manuscript Collection 7. Morgantown, WV: West Virginia Regional and History Center.

Camden, Johnson N. Photo. Morgantown, WV: West Virginia Regional and History Center. Accessed March 17, 2018. http://wvhistoryonview.org/catalog/wvulibraries:30418.

Camden v. Dewing et. al. Supreme Court of Appeals of West Virginia, December 9, 1899. The Southeastern Reports, Volume 34. Accessed March 22, 2018. https://books.google.com. 
Campbell, Archibald W. (1839-1899), Newspaperman, Papers. Archives and Manuscript Collection 14. Morgantown, WV: West Virginia Regional and History Center.

Coleman, Nelson B. Papers, Correspondence A-L. Manuscript Number MS 79-8-3. Charleston, WV: West Virginia State Archives.

Davis, Henry Gassaway. Photo, West Virginia History OnView, West Virginia and Regional History Collection, West Virginia University Libraries.

Davis, Henry Gassaway. "Speech In Mineral County Convention on Saturday, August 15, 1874." Accessed March 17, 2018.

https://babel.hathitrust.org/cgi/pt?id=loc.ark:/13960/t6k076z88;view=1up;seq=7.

Debar, Joseph H. Diss. Drawing of Abraham Lincoln and Peter G. Van Winkle. June 1864.

Diss Debar Collection. West Virginia State Archives. Accessed March 17, 2018.

http://www.wvculture.org/history/gallery/sthd/sthd43.html.

The Elkins Inter-Mountain. Accessed January 27, 2018. http://www.wvculture.org.

Genius of Liberty. Accessed January 27, 2018. https://virginiachronicle.com.

The Grafton Eagle. Microfilm Collection. Morgantown, WV: West Virginia Regional and History Center.

"Grafton, WV, photo circa 1890, showing the Baltimore and Ohio Railroad yards." WV History OnView. Accessed March 30, 2018. http://wvhistoryonview.org/catalog/wvulibraries:11956.

"Harrison County, Virginia, Petition to the Virginia General Assembly," December 31, 1855. Legislative Petitions Digital Collection, Library of Virginia, Richmond, VA.

http://digitooll.lva.lib.va.us, February 20, 2018.

Jefferson, Thomas. Letter to George Washington, March 15, 1784. Ronald M. Gephart, ed., Letters of Delegates to Congress: 1774 to 1789. Washington, DC: Library of Congress, 1994.

"Kanawha County Petition to the Virginia General Assembly, December 7, 1859." Legislative Petitions Digital Collection. Richmond, VA: Library of Virginia. Accessed February 20, 2018. http://digitooll.lva.lib.va.us.

Lee, George H.; Goff, Waldo P.; \& Camden, Gideon D., "Legislative Petitions of the General Assembly, 1776-1865." Legislative Petitions Digital Collection. Richmond, VA: Library of Virginia. Accessed February 15, 2018. http://digitooll.lva.lib.va.us.

Lewisburg Court of Appeals 1838-1840. Manuscript Collection Number MS 79-83. Charleston, WV: West Virginia State Archives. 
Lewisburg Court of Appeals 1841-1843. Manuscript Collection Number MS 79-83. Charleston, WV: West Virginia State Archives.

Lewisburg Court of Appeals 1850-1853. Manuscript Collection Number MS 70-83. Charleston, WV: West Virginia State Archives.

Madison, James. May 7, 1787, "Vices of the Political System of the U. States." Accessed January 13, 2018. https://www.loc.gov/resource/mjm.02_1005_1013/?sp=7\&st=text.

The Monongalia Mirror. Microfilm Collection. Morgantown, WV: West Virginia Regional and History Center.

New Gauley Coal Company v. Hon. I.C. Herndon, Judge, etc., et. al., No. 5201, Supreme Court of Appeals of West Virginia, decided April 20, 1926. Accessed March 22, 2018.

https://westvirginia.lexroll.com/coal-corp-v-herndon-101-w-va-445-1926/.

Parkersburg Gazette. Microfilm Collection. Morgantown, WV: West Virginia and Regional History Center.

Parkersburg Sentinel. Accessed January 27, 2018.

www.wvculture.org/history/businessandindustry/camdenjohnson02.html.

Philippi Plaindealer. Microfilm Collection. Morgantown, WV: West Virginia and Regional History Center.

Proceedings and Debates of the Virginia State Convention of 1829-30: To Which are Subjoined the New Constitution of Virginia, and the Votes of the People. Richmond, VA: Samuel

Shepherd \& Co., for Ritchie \& Cook, 1830.

Property at and Near Grafton, WV. Manuscript Collection Number 16.1.9, 75, MS2003, 4130. Baltimore, MD: Hays T. Watkins Research Library of the B\&O Railroad Museum Archives.

Reports of Cases Argued and Decided in the Supreme Court of the United States, Book 39 (The Lawyers Co-Operative Publishing Co., 1901), 1022. Accessed March 22, 2018.

http://books.google.books.

Rich v. Braxton, 158 U.S. 375 (1895). Accessed March 22, 2018.

https://supreme.justia.com/cases/federal/us/158/375/case.html.

Robinson Family Manuscripts Collection. Archives and Manuscripts Collection Number 2662. Morgantown, WV: West Virginia and Regional History Center.

Ruffner, Lewis Collection. Manuscript Collection Number MS 80-212. Charleston, WV: West Virginia State Archives.

Smith, William Prescott. The Book of the Great Railway Celebrations of 1857: Embracing a Full Account of the Opening of the Ohio \& Mississippi, and the Marietta \& Cincinnati Railroads, and 
the Northwestern Branch of the Baltimore and Ohio Railroad with Histories and Descriptions of the Same; and an Account of the Subsequent Excursion to Baltimore, Washington and Norfolk, and the Receptions and Entertainments there of the State Authorities of Ohio, and the Municipal Representatives of St. Louis, Cincinnati and Chillicothe (New York: D. Appleton \& Co., 1858).

Strother, David Hunter, writing as "Porte Crayon." "Artists' Excursion Over the Baltimore \& Ohio Rail Road," Harper's New Monthly Magazine, June 1859. Accessed November 6, 2017 http://www.catskillarchive.com/rrextra/abboa.html.

Summers, Judge Lewis Collection. Ms80-131 thru Ms80-187. Charleston, WV: State Archives, Charleston, WV.

Taxes in West Virginia (excepting Hampshire County). MS 2003, 1517. Baltimore, MD: Hays T. Watkins Research Library of the B\&O Railroad Museum Archives.

U.S. Census Data, 1850 and 1860 Virginia (by county), select data extracted via Steven Manson, Jonathan Schroeder, David Van Riper, and Steven Ruggles. IPUMS National Historical Geographic Information System: Version 12.0 [Database]. Minneapolis: University of Minnesota. 2017. Accessed February 3, 2018. http://doi.org/10.18128/D050.V12.0

U.S. Census, 1850, Jefferson County, Kentucky. Accessed January 23, 2018. https://www.ancestrylibrary.com.

U.S. Census Slave Schedule, 1850, Jefferson County, Kentucky. Accessed January 23, 2018. https://www.ancestrylibrary.com.

U.S. Census, 1860, Kanawha County, Virginia. Accessed January 23, 2018.

https://www.ancestrylibrary.com.

1850 U.S. Census, Barbour County, VA, digital image. Accessed October 10, 2017. https://www.ancestrylibrary.com.

1850 U.S. Census, Taylor County, VA, digital image. Accessed October 10, 2017. https://www.ancestrylibrary.com.

1860 U.S. Census, Barbour County, VA, digital image. Accessed October 10, 2017. https://www.ancestrylibrary.com.

1860 U.S. Census, Taylor County, VA, digital image. Accessed October 10, 2017. https://www.ancestrylibrary.com.

Van Winkle, Peter Godwin (1808-1872) Letter. Archives and Manuscript Collection Number 18. Morgantown, WV: West Virginia and Regional History Center.

Van Winkle, Peter Godwin (1808-1872), Letter and Receipt for Stock. Archives and Manuscript Collection Number 142. Morgantown, WV: West Virginia and Regional History Center. 
Van Winkle, Peter Godwin (1808-1872) Papers. Archives and Manuscript Collection Number 136. Morgantown, WV: West Virginia Regional History Center.

Van Winkle, Peter Godwin. Photograph, c. 1864. West Virginia Regional History Center, OnView. Accessed March 17, 2018.

http://wvhistoryonview.org/imageviewer/wvulibraries:44163/digitalImage.

Webster County, West Virginia, Deed Book 16. Webster Springs, WV: Webster County Courthouse.

Webster County, West Virginia Deed Book 17. Webster Springs, WV: Webster County Courthouse.

Webster County, West Virginia Deed Book 19. Webster Springs, WV: Webster County Courthouse.

Webster County, West Virginia Deed Book 22. Webster Springs, WV: Webster County Courthouse.

West Virginia, illustrated county vote on statehood issue. Accessed March 17, 2018. https://civilwartalk.com/threads/west-virginia-statehood-vote-map.13132/.

Wheeling Intelligencer. Accessed September 8, 2017. http://www.wvculture.org/history/transportation/bando02.html.

Wheeling Daily Intelligencer. Microfilm Collection. Morgantown, WV: West Virginia and Regional History Center.

Willey, Waitman T.. "Speech on Mr. Moore's Resolutions on Federal Relations, In the Convention of Virginia, March 2, 1861." Accessed January 31, 2018.

http://www.wvculture.org/history/sesquicentennial/18610304.html.

Woods, Samuel Family Papers. Archives and Manuscript Collection1111. Morgantown, WV: West Virginia and Regional History Center. 


\section{$\underline{\text { Secondary Sources }}$}

Adams, Sean Patrick. Old Dominion, Industrial Commonwealth: Coal, Politics, and Economy in Antebellum America. Baltimore, MD: The Johns Hopkins University Press, 2004.

Adams, Sean Patrick. "Soulless Monsters and Iron Horses: The Civil War, Institutional Change, and American Capitalism," in Capitalism Takes Command: The Social Transformation of Nineteenth-Century America, edited by Michael Zakim and Gary J. Kornblith, 249-276. Chicago: The University of Chicago Press, 2012.

Adas, Michael. Machines as the Measure of Men: Science, Technology, and Ideologies of Western Dominance. Ithaca, NY: Cornell University Press, 1989.

Ambler, Charles. Francis H. Pierpont: Union War Governor of Virginia and Father of West Virginia. Chapel Hill, NC: The University of North Carolina Press, 1937.

Ambler, Charles. Sectionalism in Virginia from 1776-1861. New York: Russell \& Russell, Inc., 1964.

Armitage, David. The Ideological Origins of the British Empire. New York: Cambridge University Press, 2000.

Baas, Jacob C. Jr., "John Jay Jackson, Jr.: Business, Legal and Political Activities, 1847-1859." West Virginia History, Vol. 50 (1991): 63-78. Accessed January 13, 2018. http://www.wvculture.org/history/journal_wvh/wvh50-4.html.

Barnes, L. Diane. "Booster Ethos: Community, Image, and Profit in Early Clarksburg." West Virginia History Volume 56 (1997): 27-42. Accessed September 8, 2017. http://www.wvculture.org/history/journal_wvh/wvh56-2.html.

Beckert, Sven. The Monied Metropolis: New York City and the Consolidation of the American Bourgeoisie, 1850-1896. Cambridge, NY: Cambridge University Press, 2001.

Binder, John J. "The Transportation Revolution and Antebellum Sectional Disagreement." Social Science History, Volume 35, Number 1 (Spring 2011): 19-57. Accessed August 29, 2017. http://www.jstor.org/stable/23026430.

Byrne, Frank J. Becoming Bourgeois: Merchant Culture in the South, 1820-1865. Lexington, KY: The University Press of Kentucky, 2006.

Cohn, Scott. "In an Economic Death Spiral: West Virginia is America's Worst State for Business in 2017." Accessed March 30, 2018. https://www.cnbc.com/2017/07/11/west-virginia-americas-worst-state-for-business-in2017.html. 
Conley, Phil. History of the West Virginia Coal Industry. Charleston, WV: Education Foundation Inc., 1960.

Cook, Eli. The Pricing of Progress: Economic Indicators and the Capitalization of American Life. Cambridge, MA: Harvard University Press, 2017.

Curry, Richard Orr. A House Divided: A Study of Statehood Politics and the Copperhead Movement in West Virginia. Pittsburgh, PA: University of Pittsburgh Press, 1964.

Dilts, James D. The Great Road: The Building of the Baltimore and Ohio, the Nation's First Railroad, 1828-1853. Stanford, CA: Stanford University Press, 1993.

Du Rivage, Justin. Revolution Against Empire: Taxes, Politics, and the Origins of American Independence. New Haven, CT: Yale University Press, 2017.

Dunaway, Wilma A. The First American Frontier: Transition to Capitalism in Southern Appalachia, 1700-1860. Chapel Hill, NC: The University of North Carolina Press, 1996.

Fones-Wolf, Ken. “A House Redivided From Sectionalism to Political Economy in West Virginia," in Reconstructing Appalachia, ed. Andrew L. Slap. Lexington, KY: University Press of Kentucky, 2010: 237-268. http://www.jstor.org/stable/j.ctt2jctwj.13.

Fones, Wolf, Ken and Lewis, Ronald L. Transnational West Virginia: Ethnic Communities and Economic Change, 1840-1940. Morgantown, WV: West Virginia University Press, 2002.

Fox-Genovese, Elizabeth and Eugene D. Genovese. Fruits of Merchant Capital: Slavery and Bourgeois Property in the Rise and Expansion of Capitalism. New York: Oxford University Press, 1983.

Frehling, William W. and Simpson, Craig M., editors. Showdown in Virginia: The 1861 Convention and the Fate of the Union. Charlottesville, VA: University of Virginia Press, 2010.

Griffin, Patrick. American Leviathan: Empire, Nation, and Revolutionary Frontier. New York: Hill and Wang, 2007.

Haas, Johanna Marie, J.D. Law and Property in the Mountains: A Political Economy of Resource Land in the Appalachian Coalfields. PhD Dissertation, The Ohio State University, 2008.

Hogeland, William. The Whiskey Rebellion: George Washington, Alexander Hamilton, and the Frontier Rebels Who Challenged America's Newfound Sovereignty. New York: Scribner, 2006.

Lewis, Ronald. The Industrialist and the Mountaineer: The Eastham-Thompson Feud and the Struggle for West Virginia's Timber Frontier. Morgantown, WV: West Virginia University Press, 2017. 
Link, William A. "'This Bastard New Virginia': Slavery, West Virginia Exceptionalism, and the Secession Crisis," West Virginia History: A Journal of Regional Studies, New Series, Volume 3, Number 1 (Spring 2009): 37-56.

Marrs, Aaron W. "The Iron Horse Turns South: A History of Antebellum Southern Railroads." Enterprise \& Society, Volume 8, No. 4 (December 2007): 784-789. Accessed January 13, 2018. http://www.jstor.org/stable/23700764.

Mason, Matthew. "Paddy vs. Paddy: Labor Unrest and Provincial Identities along the Baltimore and Ohio Railroad, 1849-1851." In Transnational West Virginia: Ethnic Communities and Economic Change, 1840-1940, edited by Ken Fones-Wolf and Ronald L. Lewis, 3-17. Morgantown, WV: West Virginia University Press, 2002.

Mayville, Luke. John Adams and the Fear of American Oligarchy. Princeton, NJ: Princeton University Press, 2016.

Maxwell, Hu. The History of Barbour County, West Virginia: From its Earliest Exploration and Settlement to the Present Time. Morgantown, WV: The Acme Publishing Company, 1899.

McCormick, Thomas "From Old Empire to New: The Changing Dynamics and Tactics of American Empire," in Colonial Crucible: Empire in the Making of the Modern American State, edited by Alfred W. McCoy and Francisco A. Scarano, 63-79. Madison, WI: The University of Wisconsin Press, 2009.

Myers, Mrs. Hu C., Barbour County Historical Society. "Philippi B\&O Railroad Station" National Register of Historic Places Nomination Form. Washington, DC: U.S. Department of Interior, National Park Service, November 25, 1985. Accessed August 29, 2017. https://npgallery.nps.gov/NRHP.

Noe, Kenneth. Southwest Virginia's Railroad: Modernization and the Sectional Crisis. Urbana, IL: University of Illinois Press, 1994.

Pagden, Anthony. Lords of All the World. New Haven, CT: Yale University Press, 1995.

Phillips, Christopher. The Rivers Ran Backward: The Civil War and the Remaking of the American Middle Border. New York: Oxford University Press, 2016.

Pudup, Mary Beth, Billings, Dwight B., and Waller, Altina L., eds. Appalachia in the Making: The Mountain South in the Nineteenth Century. Chapel Hill, NC: The University of North Carolina Press, 1995.

Rasmussen, Barbara, Absentee Landowning and Exploitation in West Virginia, 1760-1920. University Press of Kentucky, 1994. Accessed June 23, 2017. http://www.jstor.org/stable/j.ctt130jaj0. 
Reed, Paula Stoner. "Grafton Downtown Commercial Historic District,” National Register of Historic Places Nomination Form. Washington, DC: U.S. Department of Interior, National Park Service, September, 1983. Accessed August 29, 2017. https://npgallery.nps.gov.

Richardson, Heather Cox. West from Appomattox: The Reconstruction of America after the Civil War. New Haven, CT: Yale University Press, 2007.

Robbins, William G. Colony \& Empire: The Capitalist Transformation of the American West. Lawrence, KS: University Press of Kansas, 1994.

Rohrbacher, Walter. "A History of the Letcher Guards and the Twenty-Fifth Virginia Infantry Regiment.” MA Thesis, West Virginia University, 2005.

Ross, Thomas Richard. Henry Gassaway Davis: An Old-Fashioned Biography. Parsons, WV: McClain Printing Company, 1994.

Sexton, Jay. "Steam Transport, Sovereignty, and Empire in North America, circa 1850-1885." The Journal of the Civil War Era, Volume 7, Number 4 (December 2017): 620-647.

Shaffer, John W. Clash of Loyalties: A Border County in the Civil War. Morgantown, WV: West Virginia University Press, 2003.

Shaffer, John W. Union and Confederate Soldiers and Sympathizers of Barbour County, West Virginia. Baltimore, MD: Clearfield Company, Inc., 2005.

Stealey, John E. III. The Antebellum Kanawha Salt Business and Western Markets. Morgantown, WV: West Virginia University Press, 2016.

Stealey, John E. III. West Virginia's Civil War-Era Constitution: Loyal Revolution, Confederate Counter-Revolution, and the Convention of 1872. Kent, OH: The Kent State University Press, 2013.

Stiles, T.J. The First Tycoon: The Epic Life of Cornelius Vanderbilt. New York: Alfred A. Knopf, 2009.

Stoll, Steven. Ramp Hollow: The Ordeal of Appalachia. New York: Hill and Wang, 2017.

Stover, John F. History of the Baltimore and Ohio Railroad. West Lafayette, IN: Purdue University Press, 1987.

Summers, Festus P. Johnson Newlon Camden: A Study in Individualism. New York: G.P. Putnam's Sons. 1937. 
Super, Joseph. "West Virginia Incorporated: Religion and the Railroad in the Timber Counties." West Virginia History: A Journal of Regional Studies, New Series, Volume 7, Number 2, Fall 2013, 33-62. Accessed March 22, 2018.

https://muse-jhu-edu.www.libproxy.wvu.edu/article/523934/pdf.

Thomas, William G. The Iron Way: Railroads, the Civil War, and the Making of Modern America. New Haven, CT: Yale University Press, 2011.

Towers, Frank. The Urban South and the Coming of the Civil War. Charlottesville, VA: University of Virginia Press, 2004.

Walbert, David. “Occupations in 1860,” Learn NC. Accessed September 22, 2017. http://www.learnnc.org/lp/editions/nchist-antebellum/5350.

Waller, Altina. Feud: Hatfields, McCoys, and Social Change in Appalachia, 1860-1900. Chapel Hill, NC: The University of North Carolina Press, 1988.

Wallis, John Joseph. "Constitutions, Corporations, and Corruption: American States and Constitutional Change, 1842 to 1852. The Journal of Economic History, Vol. 65, No. 1 (Mar., 2005): 211-256. Accessed September 17, 2017. http://www.jstor.org/stable/3875048.

Ward, James A. Railroads and the Character of America. Knoxville, TN: The University of Tennessee Press, 1986.

White, Richard. Railroaded: The Transcontinentals and the Making of Modern America. New York: W.W. Norton \& Company, 2011.

Whitener, Evert F. A.B. "Peter Godwin Van Winkle." MA Thesis, West Virginia University, 1929.

Williams, John Alexander. "Class, Section, and Culture in Nineteenth-Century West Virginia Politics." In Appalachia in the Making: The Mountain South in the Nineteenth Century, edited by Mary Beth Pudup, Dwight B. Billings, Altina L. Waller, 2010-232. Chapel Hill, NC: The University of North Carolina Press, 1995.

Williams, John Alexander. Davis and Elkins of West Virginia: Businessmen in Politics. PhD Dissertation, Yale University, 1967.

Williams, John Alexander. West Virginia and the Captains of Industry. Morgantown, WV: West Virginia University Press, 2003.

Woods, Michael E. Emotional and Sectional Conflict in the Antebellum United States. New York: Cambridge University Press, 2014.

Zakim, Michael and Kornblith, Gary, editors. Capitalism Takes Command: The Social Transformation of Nineteenth-Century America. Chicago: The University of Chicago Press, 2012. 